\title{
Canada: 2017 Article IV Consultation- Press Release and Staff Report
}




\title{
INTERNATIONAL MONETARY FUND
}

\section{CANADA}

IMF Country Report No. 17/210

\section{ARTICLE IV CONSULTATION-PRESS RELEASE AND STAFF REPORT}

Under Article IV of the IMF's Articles of Agreement, the IMF holds bilateral discussions with members, usually every year. In the context of the 2017 Article IV consultation with Canada, the following documents have been released and are included in this package:

- A Press Release summarizing the views of the Executive Board as expressed during its July 5, 2017 consideration of the staff report that concluded the Article IV consultation with Canada.

- The Staff Report prepared by a staff team of the IMF for the Executive Board's consideration on July 5, 2017, following discussions that ended on May 31, 2017, with the officials of Canada on economic developments and policies. Based on information available at the time of these discussions, the staff report was completed on June 21, 2017.

- An Informational Annex prepared by the IMF staff.

The documents listed below have been or will be separately released.

Selected Issues

The IMF's transparency policy allows for the deletion of market-sensitive information and premature disclosure of the authorities' policy intentions in published staff reports and other documents.

\author{
Copies of this report are available to the public from \\ International Monetary Fund $\bullet$ Publication Services \\ PO Box $92780 \bullet$ Washington, D.C. 20090 \\ Telephone: (202) 623-7430 • Fax: (202) 623-7201 \\ E-mail: publications@imf.org Web: http://www.imf.org
}

Price: $\$ 18.00$ per printed copy

\section{International Monetary Fund Washington, D.C.}


Press Release No. 17/278

FOR IMMEDIATE RELEASE

July 13,2017
International Monetary Fund

$70019^{\text {th }}$ Street, NW

Washington, D. C. 20431 USA

\section{IMF Executive Board Concludes 2017 Article IV Consultation with Canada}

On July 5, 2017, the Executive Board of the International Monetary Fund (IMF) concluded the Article IV consultation ${ }^{1}$ with Canada. The 2017 Article IV consultation centered on policies to secure stronger, inclusive, and self-sustaining growth, while preventing the further build-up of housing market imbalances.

The economy has regained momentum, supported by the authorities' pro-active growth strategy, but complex adjustments are still at play. While personal consumption is robust, business investment remains weak, non-energy exports have underperformed, and housing market imbalances have risen. Externally, the global outlook has improved, but uncertainty surrounding global trade and risks of economic fragmentation may negatively affect the durability of the Canadian recovery.

The positive momentum in the economy is expected to continue in the near term. A strong U.S. economy, expansionary fiscal and monetary policy, and stable oil prices are expected to lift real GDP growth to 2.5 percent in 2017 and 1.9 percent in 2018. Residential construction is expected to expand at a more moderate pace, reflecting tighter macroprudential measures. The increase in exports and stable domestic demand will generate growth in business investment and, along with an increase in national savings, narrow the current account deficit to 3 percent of GDP by 2018 .

The medium-term outlook is less upbeat because of structural impediments. Weak external competitiveness, low labor productivity growth, and population aging are expected to limit potential growth to about 1.8 percent, below the recent average of 2.6 percent.

Risks to the outlook are significant. On the upside, stronger-than-expected growth in the U.S. could boost export and investment in the near term. On the downside, risks stem from several potential factors - including the risk of a sharp correction in the housing market, high uncertainty surrounding U.S. policies, or a further decline in oil prices - that can be mutually reinforcing. Policy choices will therefore be crucial in shaping the outlook and reducing risks.

\footnotetext{
${ }^{1}$ Under Article IV of the IMF's Articles of Agreement, the IMF holds bilateral discussions with members, usually every year. A staff team visits the country, collects economic and financial information, and discusses with officials the country's economic developments and policies. On return to headquarters, the staff prepares a report, which forms the basis for discussion by the Executive Board.
} 


\section{Executive Board Assessment ${ }^{2}$}

Directors commended the authorities for successfully reinvigorating the Canadian economy, although they noted that the ongoing recovery is skewed toward consumption. At the same time, there are uncertainties around the economic outlook.

Directors agreed that fiscal policy should be geared toward ensuring that the cyclical recovery is secure and inclusive. The fiscal stance should remain expansionary in 2017, while in 2018, as the output gap closes, no further increase in the deficit would be required. Directors noted that if downside risks materialized, additional fiscal stimulus should be the first line of defense. At the provincial level, fiscal consolidation should continue but at a gradual pace. Directors emphasized that maintaining fiscal discipline over the medium term will be important. They welcomed the authorities' commitment to set debt-to-GDP on a declining path, and some Directors called for the reinstatement of a fiscal rule once the economy stabilizes around its potential.

Directors agreed that monetary policy should stay accommodative and be gradually tightened as signs of durable growth and inflation pressures emerge. They recognized that monetary easing could complement fiscal stimulus, and may need to be considered along with unconventional measures if economic activity contracts significantly, although there is a risk that it could exacerbate housing imbalances.

Directors agreed that the proposed Canada Infrastructure Bank (CIB) would help foster long-term growth. Its success would depend on ensuring a transparent project selection process that balances public and private interests. Communicating clearly the CIB's benefits could help persuade the public of the need for user fees and the involvement of the private sector in public infrastructure.

Directors noted that Canada's financial sector is well capitalized and has strong profitability, but that there are rising vulnerabilities in the housing sector. In this regard, Directors generally encouraged the authorities to consider a further tightening of macroprudential and tax-based measures to protect the resilience of the household and banking sectors. Directors also encouraged the federal and provincial governments to continue to work collaboratively in addressing housing issues.

Directors took note of the differences in view between the staff and the authorities regarding the characterization of the provincial property transfer taxes on non-residents. Many Directors noted that the taxes did not have the objective to restrict capital flows and their effect on aggregate capital flows is likely minimal. While taking note of the staff's explanation that, under the

\footnotetext{
${ }^{2}$ At the conclusion of the discussion, the Managing Director, as Chairman of the Board, summarizes the views of Executive Directors, and this summary is transmitted to the country's authorities. An explanation of any qualifiers used in summings up can be found here: http://www.imf.org/external/np/sec/misc/qualifiers.htm.
} 
Institutional View on the liberalization and management of capital flows, the taxes would be considered capital flow management measures, some Directors felt that the measures appeared justified in view of the stated intent to address housing affordability concerns. Many Directors pointed to the practical challenges involved in analyzing borderline cases and formulating appropriate policy advice. In this context, a number of Directors urged staff to assess the benefits and costs of alternative macroprudential and tax-based measures vis-à-vis competing policy objectives.

Directors agreed that revitalizing productivity is key to boosting Canada's long-term growth. Structural policies should be transparent, well targeted, create an "innovation- and competition-friendly" business environment, and implemented in coordination between federal and provincial authorities. A holistic review of the tax system would help assess the scope for improving efficiency, while maintaining Canada's tax competitiveness. More could also be done to reduce FDI restrictions and regulatory barriers to entry in key sectors of the economy.

Directors agreed that diversifying Canada's export markets would facilitate its integration into global supply chains. They commended the Comprehensive Economic and Trade Agreement with the EU and encouraged Canada to pursue closer trade integration with Asia. 
Canada: Selected Economic Indicators

(Percentage change, unless otherwise indicated)

\begin{tabular}{|c|c|c|c|c|c|c|}
\hline & & & & & Proje & \\
\hline & 2013 & 2014 & 2015 & 2016 & 2017 & 2018 \\
\hline Output and Demand & & & & & & \\
\hline Real GDP & 2.5 & 2.6 & 0.9 & 1.5 & 2.5 & 1.9 \\
\hline Total domestic demand & 2.1 & 1.5 & 0.0 & 0.8 & 3.3 & 1.9 \\
\hline Private consumption & 2.6 & 2.7 & 1.9 & 2.3 & 2.4 & 1.9 \\
\hline Total investment & 3.6 & -0.3 & -5.7 & -3.9 & 5.9 & 2.1 \\
\hline Net exports, contribution to growth & 0.3 & 1.1 & 1.0 & 0.6 & -0.2 & 0.0 \\
\hline Unemployment and Inflation & & & & & & \\
\hline Unemployment rate (average) 2/ & 7.1 & 6.9 & 6.9 & 7.0 & 6.7 & 6.6 \\
\hline CPI inflation (average) & 0.9 & 1.9 & 1.1 & 1.4 & 1.9 & 2.0 \\
\hline Saving and Investment $1 /$ & & & & & & \\
\hline Gross national saving & 21.7 & 22.2 & 20.4 & 19.6 & 19.9 & 20.0 \\
\hline General government & 2.7 & 3.6 & 2.9 & 2.4 & 1.8 & 1.9 \\
\hline Private & 19.0 & 18.6 & 17.5 & 17.2 & 18.1 & 18.1 \\
\hline Gross domestic investment & 24.9 & 24.7 & 23.8 & 22.9 & 22.9 & 23.0 \\
\hline
\end{tabular}

\section{General Government Fiscal Indicators 1/}

(NA basis)

Revenue

Expenditures

$\begin{array}{llllll}38.6 & 38.6 & 39.1 & 38.9 & 38.8 & 38.8\end{array}$

Overall balance

40.1

38.6

$40.3 \quad 40.8$

$41.0 \quad 40.8$

Gross Debt

$-1.5$

0.0

$-1.1-1.9$

$-2.2$

$-2.0$

Net debt

85.8

85.4

$91.6 \quad 92.3$

90.3

89.0

29.0

27.2

25.2

$27.6 \quad 25.6$

24.3

Money and Credit (Annual average)

Household Real Credit Growth

Business Real Credit Growth

$\begin{array}{llll}3.3 & 2.2 & 3.7 & 3.8\end{array}$

3.0

2.9

Three-month treasury bill 2/

$\begin{array}{llll}6.8 & 5.6 & 7.0 & 3.7\end{array}$

3.6

4.0

Ten-year government bond yield 2/

$\begin{array}{llll}1.0 & 0.9 & 0.5 & 0.5\end{array}$

0.5

0.8

2.2

1.5

1.3

1.7

2.1

\section{Balance of Payments}

Current account balance 1/

Merchandise Trade balance 1/

$\begin{array}{rrrrrr}-3.2 & -2.4 & -3.4 & -3.3 & -3.0 & -3.0 \\ -0.4 & 0.2 & -1.2 & -1.3 & -1.1 & -1.2 \\ 2.9 & 5.7 & 3.7 & 0.5 & 1.5 & 2.8 \\ 2.0 & 2.3 & 0.3 & -1.2 & 2.4 & 2.8 \\ 0.0 & -1.3 & -6.9 & -2.0 & 1.8 & -0.4\end{array}$

Export volume

Import volume

Terms of trade

Sources: Haver Analytics and Fund staff calculations.

1/ Percent of GDP.

2/ In percent. 


\section{INTERNATIONAL MONETARY FUND}

\section{CANADA}

\section{STAFF REPORT FOR THE 2017 ARTICLE IV CONSULTATION}

June 21, 2017

\section{KEY ISSUES}

Context. The economy has regained momentum, supported by the authorities' proactive growth strategy, but complex adjustments are still at play. While personal consumption is robust, business investment remains weak, non-energy exports have underperformed, and housing market imbalances have risen. Outside of Canada, the global outlook has improved with stronger manufacturing activity, but the threat of protectionism and economic fragmentation hangs over global trade. Collectively, they raise uncertainty about the durability of the Canadian recovery.

Focus of consultation. The 2017 Article IV consultation centered on policies to secure stronger, inclusive, and self-sustaining growth, while preventing the further build-up of housing market imbalances.

Policy Challenge \#1: Securing stronger, inclusive, and self-sustaining growth

Fiscal policy should continue to take the lead in supporting the recovery, but no additional stimulus is required in 2018 since the output gap is expected to close by then. Reinstating a new fiscal rule to rebuild buffers, consistent with the authorities' commitment to placing debt on a downward path, would be useful once growth has stabilized around its potential. Monetary policy should stay accommodative and gradually tightened as signs of durable growth and inflation pressures emerge. If downside risks were to materialize, additional fiscal stimulus should be considered. While further easing of monetary policy could be a useful complement, and may need to be considered in the event of a significant shock, there is a risk that it could exacerbate housing imbalances and household debt.

Investment in infrastructure brings both short-term and long-term payoffs. Canada is well placed to implement the infrastructure program effectively but inter-governmental coordination is important to improve the visibility and accountability of public investment plans and policies. The Canada Infrastructure Bank (CIB) can be an effective instrument for mobilizing private capital to build large, revenue generating projects. The CIB should be designed to protect public interest while providing private investors with an adequate risk-adjusted rate of return.

The government's structural reform agenda to revitalize productivity by reducing barriers to internal trade, improving the innovation framework, investing in education and 
training, promoting high-skilled immigration, and providing more flexible family benefits and work arrangements to encourage women to enter and stay in the workforce, should bring sizable gains that could help reverse the declining trend in Canada's long-term growth. More can be done, however, to reduce longstanding restrictions on foreign ownership in key sectors of the economy to improve efficiency and speed-up the adoption of new technologies. To support the structural transformation of the economy, the authorities should consider a comprehensive review of the tax system to assess whether there is scope to reduce distortions and complexity, while maintaining Canada's tax competitiveness with the rest of the world. Building on the Comprehensive Economic Trade Agreement (CETA) with the EU, strengthening trade integration with Asia would help Canada diversify its export markets and find new sources of growth.

\section{Policy Challenge \#2: Tackling housing market imbalances}

While the federal authorities have introduced several rounds of macroprudential measures and tightened mortgage underwriting standards, rising imbalances call for more targeted regional measures. A combination of prudential and tax-based measures could work: caps on loan-to-income (LTI) or loan-to-value (LTV) ratios; a cap on the share of mortgages with high LTI in bank portfolios; more stringent stress test on mortgage rates (e.g. 300 basis points), with a higher spread for high LTI loans; higher property transfer tax on properties sold within a relatively short period or bought for investment purposes; or an empty home tax. Among these measures, LTI-based measures or more stringent qualification criteria for high LTI mortgages would strengthen household balance sheet resilience and reduce the probability of household defaults under downside risk scenarios. If housing markets start correcting much faster than expected, raising financial stability concerns, there may be a case to consider easing macroprudential measures.

Recent measures introduced by British Columbia and Ontario could also help reduce housing market imbalances, but the property transfer tax on non-residents could be replaced by alternative measures that are effective, not discriminatory, and do not target capital flows in line with the Fund's Institutional View on the Liberalization and Management of Capital Flows.

More comprehensive and timely data on real estate transactions, closer coordination between federal and regional authorities to manage potential spillovers and other unintended consequences of macroprudential policy, and more intensive supervisory measures to reduce the vulnerability of the real estate sector to money laundering risks, would be important to enhance financial surveillance. In addition, while Canada has a strong supervision culture, addressing gaps identified in the 2014 FSAP on regulatory mandates and operational independence would further strengthen the financial sector policy framework. 
Approved By

Krishna Srinivasan

(WHD) and

Vitaliy Kramarenko

(SPR)
Discussions took place in Toronto and Ottawa during May 15-26 and May 30-31, 2017. The team comprised Cheng Hoon Lim (head), Kotaro Ishi, Yulia Ustyugova (all WHD), Zsofia Arvai (MCM), and David Gentry (FAD). Messrs. Werner and Srinivasan (both WHD) and Ms. Horsman (ED) joined the mission for the concluding meeting in Ottawa. Ms. Young and Ms. Zorn (OED) accompanied the mission. The mission met with Finance Minister Morneau, Governor Poloz, Superintendent Rudin, Deputy Minister Rochon, Deputy Governors Lane and Schembri, other senior officials, regulators, provincial governments, representatives from the financial and business sector, academics, and think tanks. Ms. Lim presented the team's assessment of the housing market to the Senate Committee on National Finance on May 30 and gave a press conference on May 31, 2017 in Ottawa.

\section{CONTENTS}

FINDING GROWTH

A. Political Context

B. A Year of Recovery but What Happened to Investment? $\underline{5}$

C. Putting the Fiscal Space to Good Use

THE BANKING AND HOUSING NEXUS

OUTLOOK AND RISKS

POLICIES TO DEAL WITH GREATER UNCERTAINTY

A. Fiscal Policy

B. Monetary Policy

C. Financial Sector Policy

D. Trade and Structural Reforms

AUTHORITIES' VIEWS

STAFF APPRAISAL

\section{BOXES}

1. Risk Scenarios and Spillovers

2. NAFTA and Scenario Analysis of Tariff Increase

3. Infrastructure Investment 
4. Key Issues for the Proposed Canada Infrastructure Bank

5. A Talent-Based Immigration Policy

6. Gender Budget

\section{FIGURES}

1. Adjustment to Low Oil Prices is Mostly Completed

2. Canada's Labor Market has Shown Resilience $\underline{38}$

3. Financial Market Performance Remains Strong $\underline{39}$

4. External Sector Continues to Face Challenges $\underline{40}$

5a. Comparing Performance of Canadian Banks (Big-6) and G-SIBS $\underline{41}$

5b. Balance Sheet of Canadian Banking System 42

6. Housing Sector Vulnerabilities have Increased $\underline{43}$

7. Monetary Conditions Remain Favorable 44

8. Structural Policies $\underline{45}$

\section{TABLES}

1. Selected Economic Indicators $\underline{46}$

2. Balance of Payments $\underline{47}$

3. External Debt 48

4. General Government Fiscal Indicators __ 49

5. Statement of General Government Operations and Balance Sheet ___ $\underline{50}$

6. Financial Soundness Indicators___

7. Chartered Banks' Loans to Individuals__ $\underline{52}$

8. Heat Maps of Regional Housing Markets___

9. Medium-Term Scenario 2014-22___

\section{ANNEXES}

I. External Balance Assessment $\underline{55}$

II. Public Debt Sustainability Analysis $\underline{57}$

III. Housing-Related Measures to Safeguard Financial $\underline{64}$

IV. Key Findings from Canada's Detailed Assessment on AML/CFT $\underline{68}$

V. 2014 FSAP Key Recommendations and Implementation $\underline{72}$ VI. 2017 Federal Budget Measures to Enhance Innovation, $\underline{75}$ 


\section{FINDING GROWTH}

\section{A. Political Context}

1. Since it took office in November 2015, the Trudeau government has made inclusive growth a central tenet of its governing philosophy. This strategy has resonated with a public looking for economic security and change following the oil shock in mid-2014. To support the economy, the government introduced tax cuts for the middle class, expanded family benefits, and raised infrastructure spending. The fiscal stimulus, complemented by expansionary monetary policy, has succeeded in revitalizing the economy after a tough year in 2015. But even as the short-term battle is won, the more difficult challenges lie ahead:

- Growth forecasts have been gradually marked down since the oil shock. Canada's traditional engines of growth have slowed, hobbled by longstanding structural problems of low labor productivity growth and population aging. Without bold action to tackle these challenges, Canada's medium-term growth will struggle to rise above 2 percent.

- Housing market imbalances have increased. The Can $\$ 1.5$ trillion mortgage market has been important in sustaining private consumption but households are highly indebted and housing affordability, particularly in Vancouver and Toronto, has become a social issue with many first-time buyers priced out of the markets.

2. These two challenges will dominate the government's policy agenda at a time of greater uncertainty about policy outcomes in the U.S. and across the Atlantic. U.S. policies on trade and tax reform, the timing and form of the U.K.'s withdrawal from the EU, and elections in major countries in Europe, could tilt policies toward protectionism and economic fragmentation. This would have significant consequences for Canada, an economy that is highly reliant on trade and cross border flows.

\section{B. A Year of Recovery but What Happened to Investment?}

3. The economy is on the mend. GDP growth expanded by 1.5 percent in 2016, up from 0.9 percent in 2015, in a volatile year marked by the devastation of the Fort McMurray wildfires (Figure 1 and Table 1). The year started strongly with a 3.7 percent annualized first quarter growth, driven by widespread gains in final domestic demand, including strong residential investment. At this pace of expansion, the negative output gap of around 1 percent of potential GDP is beginning to close. On the positive side:

- Personal consumption was robust, as employment growth accelerated to 1.3 percent at the end of 2016, the fastest annual job growth since mid-2013, with net gains in full time jobs 
(Figures 2). ${ }^{1}$ The labor market has also absorbed workers moving from the resource to the nonresources provinces in search of new employment. With confidence returning and the housing market booming, spending on durables and other consumer goods rose.

- Energy exports have rebounded. The rise in oil prices since mid-2016 to a level above operating costs (WTI, about US\$50) has allowed oil sands producers to stay in business. The unemployment rate in the resource provinces has stabilized at around 8 percent (Alberta), and house prices have stopped falling.

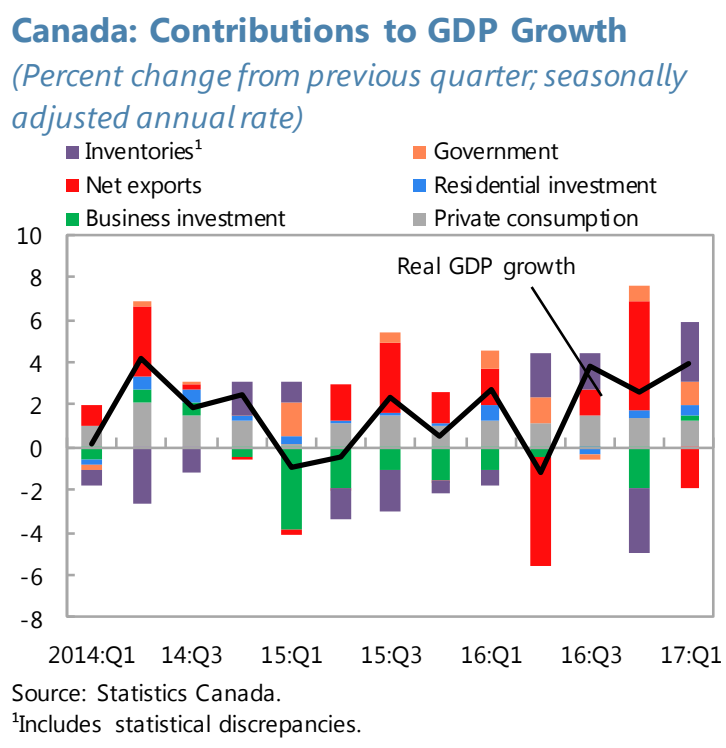

- The service sector, accounting for 70 percent of total output, has performed well with strong growth in air transport, motion pictures, computer systems design, and service exports. Finance and real estate activities (together accounting for about 28 percent of total services) rose in tandem with the housing market boom. Overall, the service sector contributed 1.5 percentage points to GDP growth in 2016 compared with a combined 0.1 percentage points in the manufacturing and the agriculture sector.



${ }^{1}$ Between December 2016 and April 2017, full time jobs increased by 108,000, whereas part time jobs declined by 22,000 . 
- Median income improved. Following a sharp dip in the 2008 recession, median income has kept pace with inflation and increased by 7.5 percent since 2010, while Canada's Gini coefficient, a measure of income inequality, has been broadly stable at about 0.32 .

\section{Conspicuously absent from the} economic recovery, however, is an important engine of growth: business investment. Low interest rates have yet to energize business investment, an issue that has been highlighted by the Bank of Canada (BOC). ${ }^{2}$ Since mid-2014, nonresidential business investment has declined by about 20 percent. Much of the decline in business investment is the result of the collapse in oil prices - the share of oil and gas in total business investment sector has dropped from about 30 percent in 2014 to 19 percent in 2016-but non-oil and gas investment has also been weak. The lack of investment can be attributed to structural factors:

- Population aging. Population aging has led to a

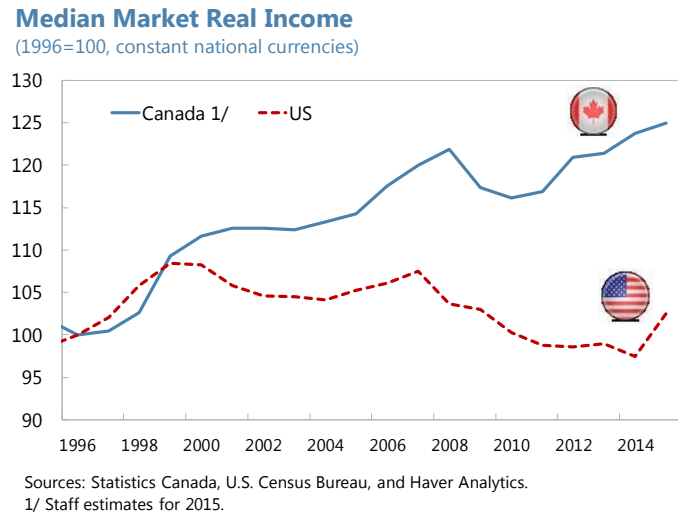

Real Private Investment Growth and its Components (Contributions to growth in percent)



2007200820092010201120122013201420152016 Sources: Statistics Canada, National Accounts and IMF staff calculations. $1 /$ Includes intellectual property and nonprofit business. marked slowdown in labor force growth, and this has been a strong headwind to investment. With baby boomers reaching retirement age, the working age population ratio (the number of individuals aged 15-64 as a share of total population) has fallen by about 2 percentage points since 2010 and is projected to fall another 7 percentage points over the next 20 years.

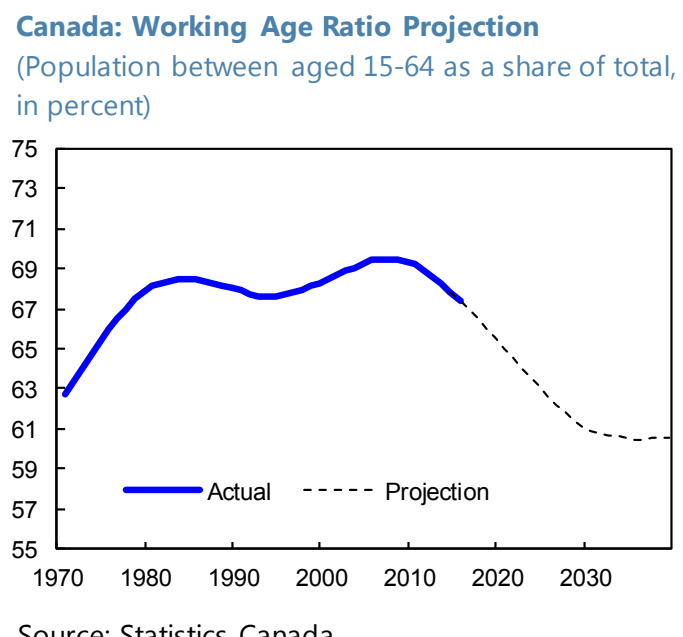

- Labor productivity growth. Low labor productivity growth is not conducive for business investment as it increases uncertainty about the strength of future demand and output. In the past decade, Canada's labor productivity growth has fallen by more than half to 0.5 percent, reflecting sluggish total factor productivity growth and to a lesser extent, a slower pace of capital accumulation.

Source: Statistics Canada.

2 See "Getting Down to Business: The Investment and Economic Outlook," remarks by Deputy Governor Schembri, Bank of Canada, March 21, 2017. 




Sources: National Statistics; and Haver Analytics.

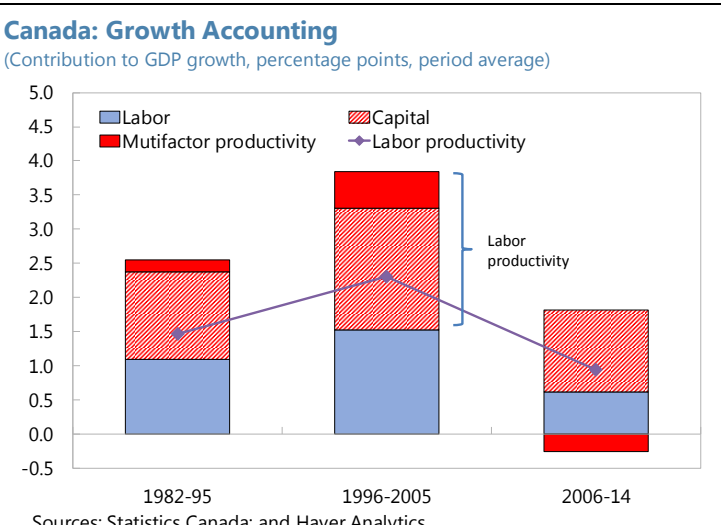

Sources: Statistics Canada; and Haver Analytics

5. Non-energy exports have also disappointed despite a $\mathbf{1 5}$ percent depreciation of the Canadian dollar since mid-2014. The lackluster performance differs from past episodes of depreciation; based on historical correlations, exports should have been about 6 percent higher in 2016. Staff research has suggested that years of low labor productivity growth has eroded Canada's external competitiveness in the manufacturing sector and caused a permanent loss of manufacturing capacity. ${ }^{3}$ The entry of China into the U.S. market following its accession to the WTO and the appreciation of the Canadian dollar during the oil boom in the mid-2000s made the problem worse. Canada's early gains in NAFTA have been diminished. Today, Canada's export share in the U.S. market for non-resource goods is about 11 percent, half of what it used to be in the mid-1990s. Canada still has a competitive advantage in the service sector, but even in this area, Mexico and China are catching up.

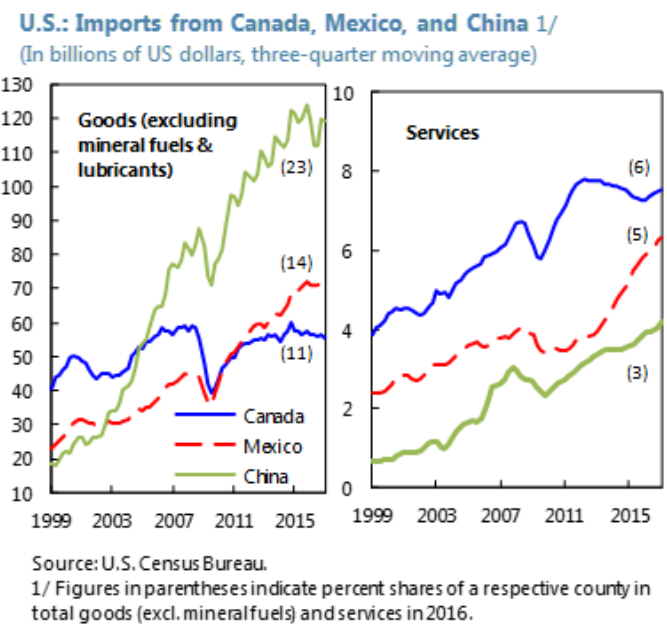

3The 2016 Article IV Staff Report Appendix I "Trade Competitiveness in Canada" provided detailed analysis of Canada's structural loss in external competitiveness. The work was later developed into an IMF working paper "Products and Provinces: A Disaggregated Panel Analysis of Canada's Manufacturing Exports", IMF WP 16/193, 2016 by I. Agur. 


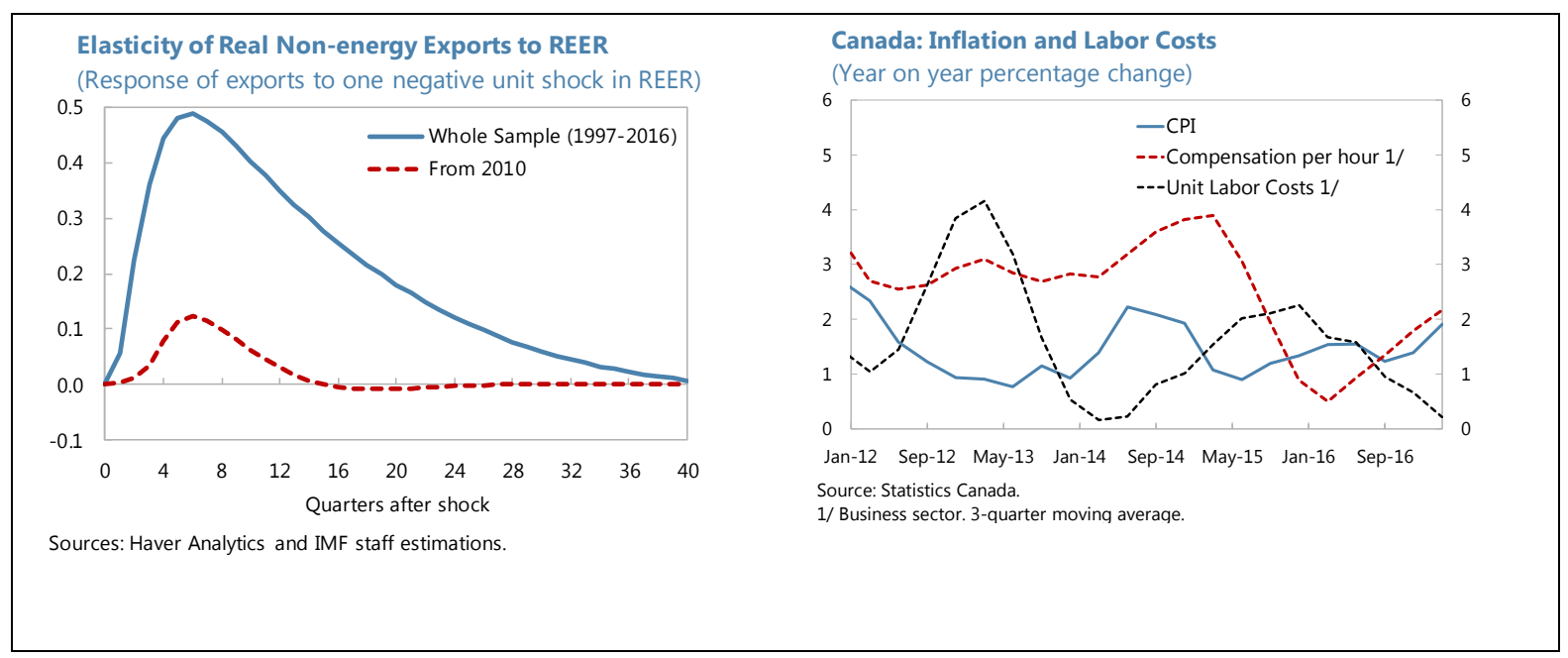

6. With the persistent slack in the economy and no wage pressures, inflation and inflation expectations have remained subdued. For most of last year, headline CPI inflation hovered between 1-1.5 percent, below the mid-point of the BOC's target band (1-3 percent), although it rose to about 2 percent in early 2017 due to gasoline price increases. All three core inflation measures have remained below 2 percent since late 2016, reflecting diminishing effects of the exchange rate pass-through and the slack in the economy. More broadly, total hours worked has been broadly flat and unit labor costs have increased by only 1 percent, posing little upward push to inflation.

\section{Long-term rates, however, have increased in line with the rise in U.S. treasury} yields. The U.S. Federal Reserve has raised the Fed funds rate twice since December and the markets are pricing in additional rate increases in 2017. As expected, Canadian long-term yields have followed suit, steepening the yield curve, but so far, the effective cost of borrowing has remained low and markets do not expect the BOC to hike rates soon (Figure 3 and 7).

\section{The current account deficit narrowed slightly but the external position is moderately weaker than justified by fundamentals and desirable policies, and the} Canadian dollar remains overvalued. The current account balance recorded a marginal improvement, from -3.4 percent of GDP in 2015 to -3.3 percent of GDP in 2016 (Figure 4 and Tables 2-3). A higher merchandise trade deficit was offset by an improved trade balance in services due to stronger sales of commercial and travel services. With foreign direct investment recording a net outflow, the current account deficit was financed by net portfolio inflows (Annex I). Overall, despite rising external debt, Canada remains a net creditor to the rest of the world. 


\section{Putting the Fiscal Space to Good Use}

9. Canada has some fiscal space and is proactively using it to support growth, consistent with previous Fund advice. Although general government gross debt is relatively high at over 92 percent of GDP, with sizable financial assets (about 64 percent of GDP), general government net debt is only 28 percent of GDP, far below the advanced economy average of 72 percent of GDP (Tables 4-5). Market confidence in Canada's fiscal prudence is high, with its sovereign long-term bonds (AAA rating) trading at a premium relative to U.S. 10-year treasury bonds. In addition, the Office of the Parliamentary Budget Officer (PBO) serves as an effective counterpoint in evaluating the consistency of overall fiscal policies and the government's medium-term fiscal forecasts. Canada's public debt remains sustainable under most stress scenarios (Annex II-Public Debt Sustainability Analysis).

10. Implementation of the stimulus measures in the 2016 Budget is on track. Stimulus measures announced in the 2016 Budget totaled 0.6 percent of GDP, and included investment in social housing, tax cuts for the middle class, an increase in child care benefits, and infrastructure investment. Implementation of these measures is broadly on track, except for a slight delay in infrastructure spending that will leave about 15 percent of the budgeted allocation (equivalent to 0.1 percent of GDP) unspent by the end of the fiscal year in March. ${ }^{4}$ The remaining allocation will be rolled over into the next fiscal year, and the government's commitment of Can $\$ 95.6$ billion in new infrastructure spending through FY2027 remains intact. The impact on GDP growth from the 2016 stimulus package is estimated at about 0.4 percentage points. ${ }^{5}$

11. Overall, the general government deficit increased by $3 / 4$ percentage points of GDP to around 2 percent of GDP in 2016. The fiscal balance was broadly flat at the provincial level

\footnotetext{
${ }^{4}$ Even if measures are not fully expensed, activity related to the project could have commenced. Payments by the federal government to local jurisdictions are often made with a lag once projects are finished or specific targets are reached.

${ }^{5}$ Staff estimates the average size of the fiscal multiplier is 0.7 .
} 
(Tables 4-5). On a cyclically adjusted basis, the general government deficit increased by $3 / 4$ percentage points to $1 \frac{1}{2} 2$ percent of GDP in 2016.

\title{
THE BANKING AND HOUSING NEXUS
}

\author{
12. Canada's large banks have a sizable \\ exposure to the housing sector. The Big- 6 banks, \\ which account for 93 percent of total banking \\ system assets, allocates about 35 percent of their \\ total assets to consumer and mortgage lending \\ and draws 50 percent of their total revenues from \\ these loans (Figure 5 and Tables 6-7). Mortgage \\ lending alone accounts for 45 percent of total \\ loans, with the share of uninsured mortgages, now \\ exceeding insured mortgages. ${ }^{6}$ Tighter
}


macroprudential rules in the insured space has caused the shift to uninsured mortgages. ${ }^{7}$

\section{The high level of household debt is a significant vulnerability for the financial}

system. Household debt-to-disposable income has reached nearly 170 percent, which is among the highest in $\mathrm{G} 7$ economies (Figure 6). The debt load is significant in Toronto and Vancouver: between 2014 and 2016, the share of high-ratio mortgage borrowers with a loan-to-income (LTI) ratio over 450 percent increased from 32 percent to 49 percent and from 31 percent to 39 percent, respectively. In May, Moody's downgraded the credit rating of the Big- 6 banks by one notch noting that the resilience of household balance sheets, and consequently bank portfolios, to a serious economic downturn has not been tested at these levels of private sector indebtedness. ${ }^{8}$ So far,

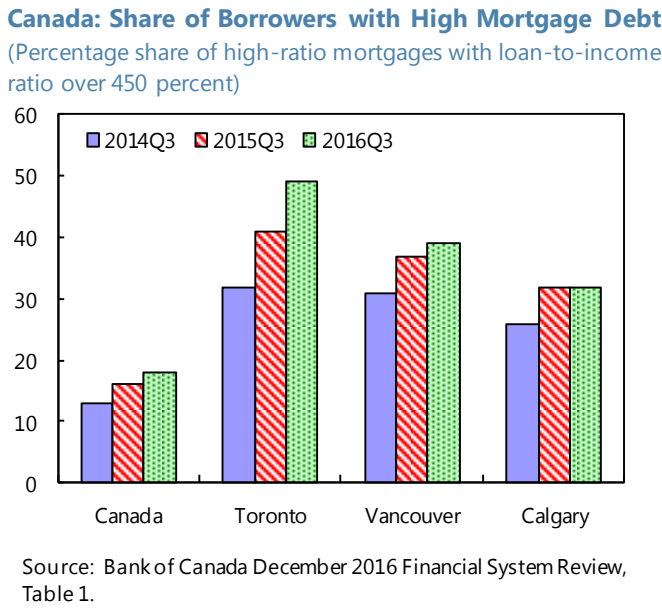

\footnotetext{
${ }^{6}$ Non-insured loans have a maximum LTV of 80 percent and are not backed by government mortgage insurance.

${ }^{7}$ Some mortgage lending has shifted to mortgage finance companies (MFCs), whose market share has grown from $\$ 5$ billion of outstanding mortgages (about 1 per cent) in 1999 to $\$ 165$ billion (about 12 per cent) in 2015. Most of the mortgages originated by MFCs are insured, either individually at origination or afterward, through portfolio insurance, and their underwriting practices are therefore subject to federal regulations.

8 The ratings downgrade came amid turmoil at Home Trust, a federally regulated mortgage lender that is part of Home Capital Group, the leading lender in Canada's Alt-A market. Home Trust experienced significant liquidity problems in April when investors withdrew more than 70 percent of their high-interest savings, and an emergency credit line (provided by the Healthcare Ontario Pension Plan) had to be arranged at a high interest rate (22 percent). While Home Capital is not a systemic risk, representing only 1 percent of the mortgage market, its problems along with Moody's downgrade sparked broader concerns about the health of the housing market.
}

(Continued) 
low interest rates have kept total debt service affordable. ${ }^{9}$ But as the U.S Fed normalizes its monetary policy, Canadian long-term rates are likely to rise in line with the increase in U.S. interest rates, foreshadowing a rise in housingrelated vulnerabilities. With house prices and household credit rising faster than nominal GDP, the gap between the business and housing cycles has widened..$^{10}$

\section{The regional divide in the housing market has become more stark. The rapid} acceleration of house prices in Vancouver and Toronto in the last two years-due to their robust economies, demographic factors, and supply constraints-widened an already large gap between these two markets and the rest of the country. On weighted average terms, in Calgary and Regina, house prices have stabilized after two years of declines while in Ottawa and Montreal, house prices are growing at a slow pace. Staff's heat maps show Vancouver and Toronto deeply in "red", with house prices accelerating at a rate that is difficult to be justified by fundamentals, while other major cities are "green" (Table 8).

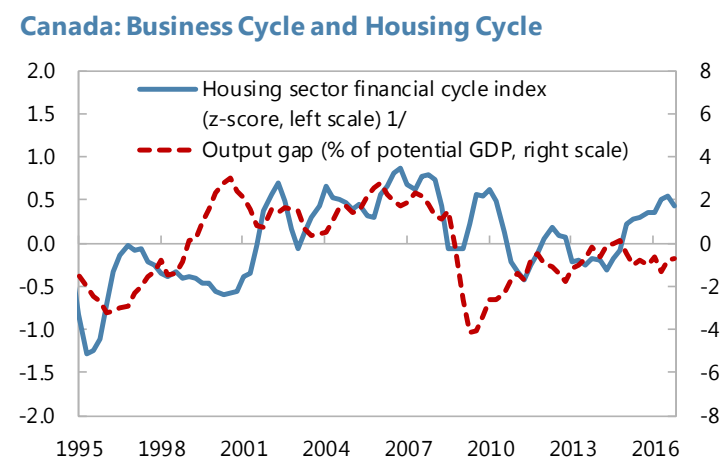

Source: IMF staff estimates

1/ Measured as average of house price growth, residential mortgage credit growth, real investment growth (all standardized z-score) and a deviation in the residential mortgage credit to GDP ratio from its historical trend.
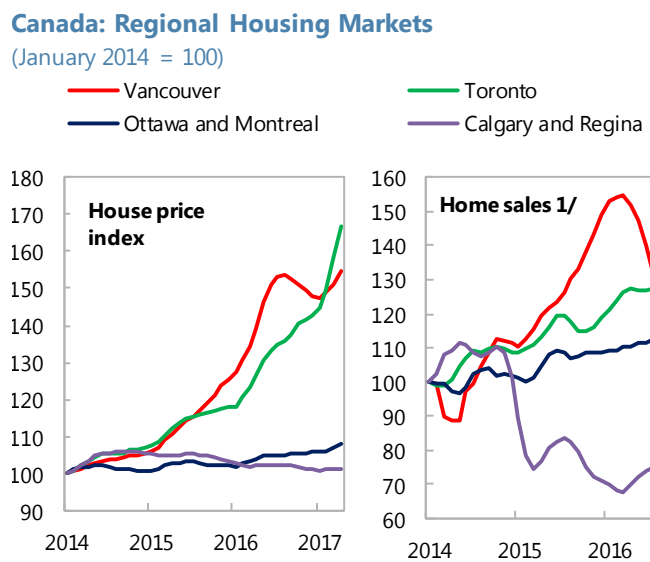

Source: Canadian Real EstateAssociation. $1 /$ Three month moving average.

- In Vancouver, house prices rose over 50 percent between mid-2013 and mid-2016. Housing activity started to slow down in early 2016, and the decline accelerated, after British Columbia introduced a property transfer tax of 15 percent on non-resident buyers in the Metro Vancouver Area in August 2016.11

\footnotetext{
9 The BOC's housing affordability index (measures the share of disposable income that a representative household would put toward housing-related expenses, including utilities) is currently 0.34 , compared to 0.39 at the peak of the crisis in 2008.

10 The BIS early warning indicator for domestic banking risks show Canada's credit to GDP gap (comparing the current level of the ratio of credit to GDP to its long-term trend) widening to 17.4 percentage points by the third quarter of 2016, second only to China (26.3 gap) and above the critical threshold of 10 percentage points. Under stressed conditions-a 250-basis-point increase in interest rates and assuming 100-per-cent pass-through-the debt service ratio for interest payments would rise from 3.6 percent to 7.9 percent, or 13.4 cents for every dollar of household disposable income.

${ }^{11}$ British Colombia authorities noted that foreign buyers accounted for 12.8 percent of the total value of property transfers in the province between June 10 and August 1, 2016, just before the measure was introduced, and the share of foreign buyers fell to 3.9 percent by February 2017. The authorities are starting to collect data on the
}

(Continued) 
- In Toronto, house prices have continued to surge through 2017, rising by 32 percent yearon-year in April. On April 20, the Ontario government announced 16 measures, including a 15 percent non-resident speculation tax for the Greater Golden Horseshoe region around Toronto to address "unsustainable demand in the region and make housing more available and affordable."

\section{There are safety nets in place, including strict supervision, a resilient banking system, full recourse loans, and government-backed mortgage insurance.}

- The Office of the Superintendent of Financial Institutions' (OSFI) principles-based supervision emphasizes the accountability of board directors and management for the overall safety and soundness of institutions and adherence to supervisory guidance. ${ }^{12}$ OSFI has consistently updated its expectations of residential mortgage and insurance underwriting practices (B20 and B-21 Guidelines), with a strong emphasis on rigorous income verification, nonconforming loans, debt service and LTV calculations, property appraisals and the risk profile of new mortgage loans, and full assessment of a borrower's ability to withstand plausible financial and economic shocks.

- The Big-6 banks have strong balance sheets and income positions: they have strengthened their capital ratios from 10 percent a year ago to 11.3 percent; improved their leverage ratios to 5 percent; enjoy high profitability, averaging 15 percent return on equity; maintain strong asset quality, with less than 1 percent non-performing loan ratios (NPL); and have diversified sources of funding, but with foreign assets mostly in the U.S. ${ }^{13}$

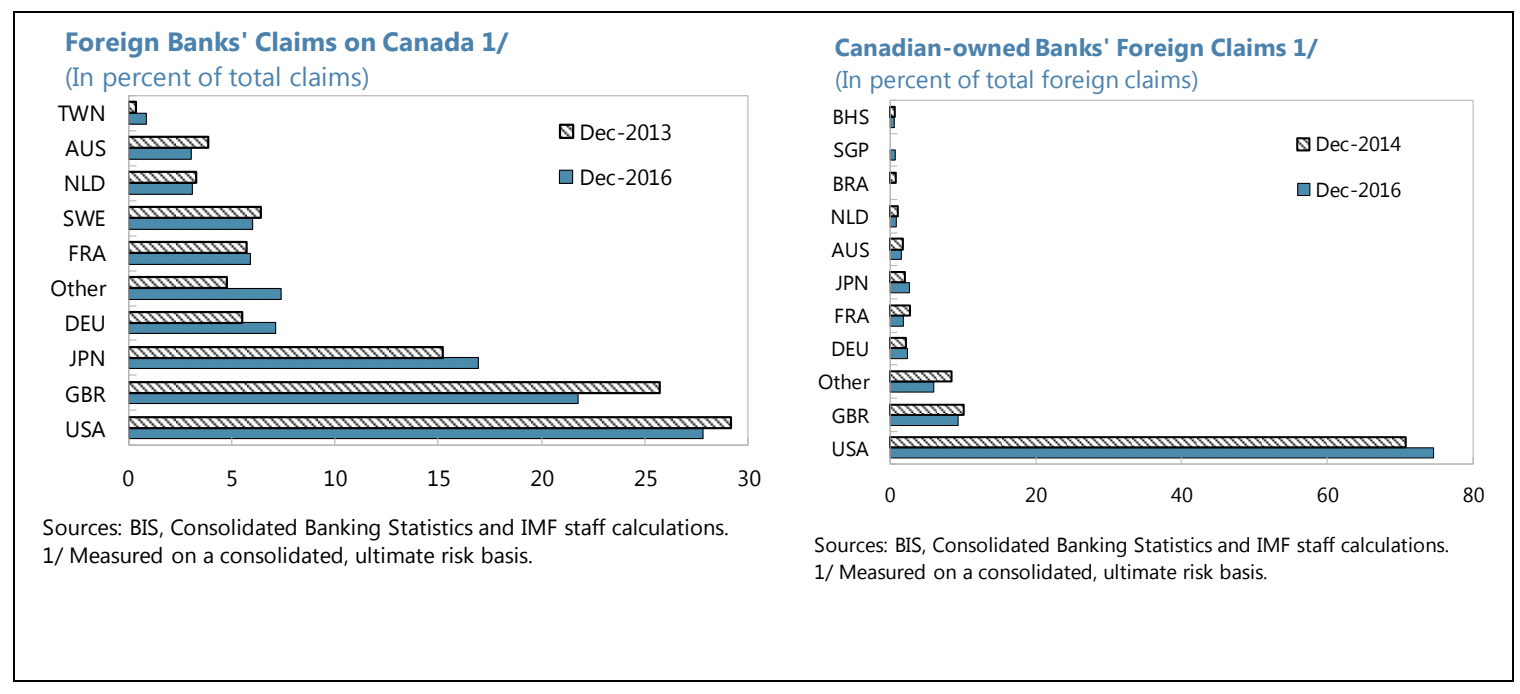

composition of real estate transactions, but as of now, there are no data prior to 2016 that indicate an increase in activity by foreign buyers.

12 See IMF FSAP Technical Note "Intensity and Effectiveness of Federal Bank Supervision in Canada", February, 2014.

13 The U.S. now accounts for about 30 percent of TD bank's total net income. 
- A government-backed mortgage finance system takes on virtually all the credit risk on insured mortgages loans, subject to strict underwriting requirements, and the interest rate on the loans resets every five years. These loans are thus a low risk for the banks. Government guarantees of insured mortgages amount to 36 percent of GDP.

- In most provinces, Canadian banks have full recourse to take legal action to recoup money from the homeowner if a foreclosed home is sold for less than the amount owed on the mortgage. ${ }^{14}$

\section{OUTLOOK AND RISKS}

16. The positive momentum in the economy is expected to continue in the near term, supported by higher domestic and external demand. A strong U.S. economy, expansionary fiscal and monetary policy, and stable oil prices are expected to lift real GDP growth to 2.5 percent in 2017 and 1.9 percent in 2018 (Table 9). After a strong first quarter, residential construction is expected to expand at a more moderate pace, with household credit growth projected to decelerate and fall below business credit growth. The slowdown in housing activity reflects more expensive mortgage financing, as long-term rates rise in response to U.S. monetary policy tightening, as well as tighter macroprudential measures. The increase in exports and stable domestic demand will generate growth in business investment and, along with an increase in national savings, narrow the current account deficit to 3.0 percent of GDP by 2018.

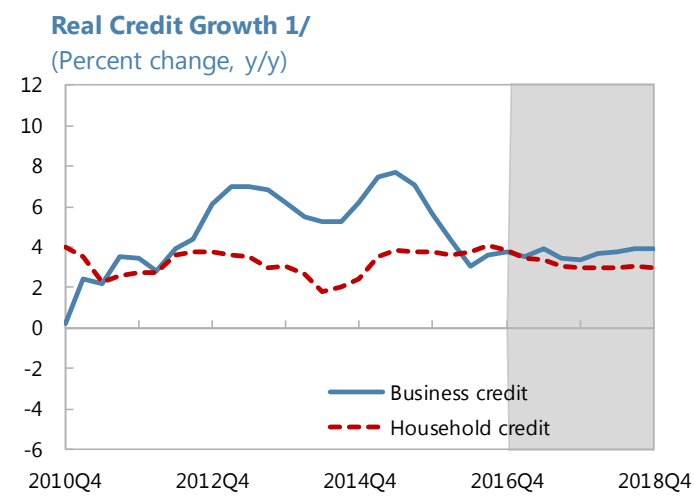

Sources: Haver Analytics and IMF staff estimates

$1 /$ The explanatory variables for forecasting household credit growth include household consumption and household borrowing interest rates, and those for business credit growth include business investment and business borrowing interest rates.

\section{The medium-term outlook is less upbeat, however, because of structural}

impediments. As the fiscal stimulus fades and the U.S. economy returns to trend, weak external competitiveness, low labor productivity growth, and population aging will limit potential growth to about 1.8 percent, lower than the recent average of 2.6 percent (2000-2008).

18. Risks to the outlook are significant (Risk Assessment Matrix). On the upside, strongerthan-expected growth in the U.S., because of less ambitious than planned spending reductions and/or lower federal revenues from tax reforms, could boost export and investment in the near term. On the downside, risks stem from several potential factors that can be mutually reinforcing. Policy choices will therefore be crucial in shaping the outlook and reducing risks.

\footnotetext{
14 The exceptions are Alberta and Saskatchewan. Alberta does not always offer recourse to lenders, based on the vintage and nature of the loan. In Saskatchewan, recourse only applies to refinanced mortgages.
} 
19. The main risk on the domestic side is a sharp correction in the housing market that impairs bank balance sheets, triggers negative feedback loops in the economy, and increases contingent claims on the government (Box 1). Financial stability risks could emerge if the housing market correction is accompanied by a severe recession. Under this scenario, the general government debt-to-GDP ratio could rise to about 100 percent of GDP (Annex II). Staff's stress test shows that banks' strong profitability and capital position, nevertheless, could withstand a significant loss on their uninsured residential mortgage portfolio; the NPL may have to increase to levels higher than seen in most advanced countries during the global financial crisis to breach the minimum requirement for common equity tier 1 capital.

20. The main risk on the external side is high uncertainty about U.S. policies and its impact on global growth. If this leads to a faster-than-expected-pace of interest rate hikes in the U.S. and a tightening of global financial conditions ensues, potential abrupt shifts in global market sentiment and a re-pricing of risk could raise the cost of funding for Canadian businesses and households, dampening domestic demand (Box 1). Beyond this, a move by the U.S. towards greater protectionism, including by imposing non-tariff barriers in a revised NAFTA or raising tariffs, would undercut growth prospects in Canada, leading to a permanent reduction in investment and consumption (Box 2). Similarly, while Canada has a competitive tax regime, a sharp reduction in the U.S. corporate tax rate may make Canada less attractive as an investment destination and discourage much needed FDI inflows. ${ }^{15}$

\section{Other external risks include structurally weaker growth in key advanced and} emerging economies and a further decline in oil prices. These could significantly reduce Canadian exports and potential growth. Banks' direct exposure to the oil sector is limited to 2 percent of total loans on average, with another 2 percent in undrawn credit lines. ${ }^{16}$

\footnotetext{
15 On its effective marginal tax rate, Canada ranks 7th out of 19 countries in 2015, but is projected to rank 10 th in year 2020 due to tax reform in other countries. On its effective average tax rate, Canada ranks 8th out of 19 countries in 2015, and is projected to rank 9th in 2020.

16 The 2016 Article IV Staff Report provided a comprehensive assessment of banking system exposure to the oil sector.
} 
Canada: Risk Assessment Matrix ${ }^{17}$

(Scale-low, medium, and high)

\begin{tabular}{|c|c|c|c|}
\hline Source of Risks & $\begin{array}{c}\text { Relative } \\
\text { Likelihood }\end{array}$ & Impact & Policy Response \\
\hline \multicolumn{4}{|c|}{ Globally-sourced risks } \\
\hline $\begin{array}{l}\text { 1. Retreat from cross } \\
\text { border } \\
\text { integration/policy } \\
\text { and geopolitical } \\
\text { uncertainties }\end{array}$ & High & $\begin{array}{l}\text { High } \\
\text { Canada is a highly open economy with total trade accounting for over } \\
60 \text { percent of GDP. A shift toward protectionism would reduce global } \\
\text { trade and cross-border investment flows, and dampen global growth. } \\
\text { Canada's export and business investment would suffer. Changes in U.S. } \\
\text { taxation and regulation could also have spillover effects on Canada's } \\
\text { key industries, particularly the auto, energy, and financial sectors that } \\
\text { directly compete or interconnect through supply chains. }\end{array}$ & \multirow{4}{*}{$\begin{array}{l}\text { Monetary policy. The BOC } \\
\text { should cut the policy rate } \\
\text { and use forward guidance to } \\
\text { keep long-term rates low. If } \\
\text { the policy rate hits the } \\
\text { effective lower bound, } \\
\text { unconventional monetary } \\
\text { policy should be introduced. } \\
\text { Fiscal policy. The federal } \\
\text { government has some fiscal } \\
\text { space, and should introduce } \\
\text { discretionary measures, } \\
\text { including bringing forward } \\
\text { the already committed } \\
\text { infrastructure spending. } \\
\text { Provinces with low } \\
\text { deficit/debt should also take } \\
\text { expansionary measures. } \\
\text { Structural reform policies } \\
\text { should be accelerated to } \\
\text { raise productivity, which } \\
\text { would improve external } \\
\text { competitiveness, trade, and } \\
\text { boost potential growth. }\end{array}$} \\
\hline $\begin{array}{l}\text { 2. Significant further } \\
\text { strengthening of } \\
\text { the US dollar } \\
\text { and/or higher rates }\end{array}$ & High & $\begin{array}{l}\text { Medium } \\
\text { A faster-than-expected pace of interest rate hikes in the U.S. that is not } \\
\text { in line with a U.S. recovery could trigger a rapid tightening in global } \\
\text { financial conditions and a sharp dollar appreciation, which would result } \\
\text { in a repricing of risk premium and a rise in Canadian long-term rates. } \\
\text { This could significantly raise the funding cost for businesses and highly } \\
\text { indebted households, causing financial hardship, a decline in private } \\
\text { consumption, and rising defaults on mortgage and consumer loans. The } \\
\text { resulting depreciation of the Canadian dollar would cushion the shock. }\end{array}$ & \\
\hline $\begin{array}{l}\text { 3. Structurally weak } \\
\text { growth in key } \\
\text { advanced and } \\
\text { emerging } \\
\text { economies }\end{array}$ & $\begin{array}{c}\text { High/ } \\
\text { Medium }\end{array}$ & $\begin{array}{l}\text { Wedium/High } \\
\text { Weak demand, low inflation, and anemic productivity growth in some } \\
\text { advanced economies would reduce demand for Canadian exports and } \\
\text { lower Canada's potential growth. A slowdown in China, possibly } \\
\text { exacerbated by capital outflow pressures, could reduce global demand } \\
\text { and output through commodity prices and global financial risk aversion. }\end{array}$ & \\
\hline $\begin{array}{l}\text { 4. Lower energy } \\
\text { prices }\end{array}$ & Low & $\begin{array}{l}\text { Medium/High } \\
\text { The terms of trade shock will take a heavy toll on resource rich } \\
\text { provinces, affecting investment, jobs, and real income, and negatively } \\
\text { affect Canada's GDP. }\end{array}$ & \\
\hline \multicolumn{4}{|c|}{ Domestically-sourced risks } \\
\hline $\begin{array}{l}\text { 5. Sharp house price } \\
\text { correction, } \\
\text { combined with a } \\
\text { sharp and } \\
\text { persistent rise in } \\
\text { unemployment }\end{array}$ & Medium & $\begin{array}{l}\text { High } \\
\text { With households highly indebted a sharp house price correction could } \\
\text { destabilize housing markets, severely impair banks' asset quality, and } \\
\text { set off negative feedback loops in the economy, with sharp contractions } \\
\text { in consumption and investment that could threaten economic and } \\
\text { financial stability. The government balance sheet would be hit by claims } \\
\text { on mortgage insurance. }\end{array}$ & $\begin{array}{l}\text { Ensure adequate loss } \\
\text { absorbing buffers in the } \\
\text { banking and insurance } \\
\text { sectors, and conduct regular } \\
\text { stress testing. } \\
\text { Macroprudential policy may } \\
\text { need to be eased as a } \\
\text { counter-cyclical measure. }\end{array}$ \\
\hline
\end{tabular}

17 The Risk Assessment Matrix shows events that could materially alter the baseline path (the scenario most likely to materialize in the view of IMF staff). The relative likelihood of risks listed is the staff's subjective assessment of the risks surrounding the baseline ("low" is meant to indicate a probability below 10 percent, "medium" a probability between 10 and 30 percent, and "high" a probability of 30 percent or more). The matrix reflects staff views on the source of risks and overall level of concern as of the time of discussions with the authorities. Nonmutually exclusive risks may interact and materialize jointly. 


\section{Box 1. Risk Scenarios and Spillovers}

Tighter global financial conditions. An increase in the U.S. term premium by 50 basis points would raise Canada's term premium by about 40 basis points. ${ }^{1,2}$ While the central bank reacts by reducing the policy rate to help counter the effect of higher long-term interest rates, tighter financial conditions will reduce investment by 0.6 percent in the short term and output by 0.1 percent over the medium term.

\section{Sharp house price correction. In} an illustrative severe downside scenario, tighter global financial conditions lead to higher debt ser Scenario 1, a 150 basis points increase in the term premium would reduce output by about 1 percent mostly through lower investment. In scenario 2 , the increase in term premium increases debt service payments, reducing disposable income, and thus household consumption by about 1 percent. In scenario 3 , where house prices drop by 30 percent in unison with the hike in term premium and debt service burden, the negative effect on real GDP would be close to 3 percent in the short term. Due to negative wealth effects, consumption would be 3.5 percent below the baseline, while investment would be lower by 18 percent, even when the central bank reacts by easing monetary policy.

${ }^{1}$ The structural simulations were estimated using the IMF's Flexible System of Global Models (FSGM). This is an annual, multiregional general equilibrium model, combining both micro-founded and reduced-form formulations of various economic sectors. It has fully articulated demand side and some supply-side features. The dynamics of export price elasticities as well as remittances and migration dynamics are calibrated to be consistent with the main stylized facts of empirical estimates.

${ }^{2}$ Apart from the other spillovers from the U.S. shock, including through trade.

${ }^{3}$ The BOC's Financial System Review (December 2014) suggested an estimated overvaluation ranging from 10 to 30 percent. 


\section{Box 2. NAFTA and Scenario Analysis of Tariff Increase}

The North American Free Trade Agreement (NAFTA) created one of the largest single markets in the world, developed complex supply chains, and led to deep economic integration among the three signatories, the U.S., Mexico, and Canada. Canada exports 74 percent of its goods to the U.S (equivalent to 23 percent of GDP) and half of the FDI to Canada comes from the U.S.

NAFTA Renegotiations. The U.S. Administration on May 18 formally notified Congressional leaders of its intention to renegotiate NAFTA, starting the 90-day consultation period with Congress required under Trade Promotion Authority provisions. This means that the formal negotiations could begin as early as midAugust. The notification does not specify negotiating objectives but notes that NAFTA needs to be "modernized" to include new provisions in areas such as intellectual property rights, regulatory practices, state-owned enterprises, services, labor, and environment. While the focus of NAFTA talks appears to be on non-tariff provisions, the threat of tariffs remains on the table. ${ }^{1}$ The negotiations could also update specific sectoral agreements in NAFTA, including on dairy products. The detailed U.S. negotiating objectives are expected to be shared with Congress at least 30 days prior to the start of negotiations.

Scenario analysis of a tariff increase. If the U.S. raises the average tariff on imports from Canada by 2.1 percentage points to the WTO mostfavored nation level, and there is no retaliation from Canada, simulations based on the IMF Global Integrated Monetary and Fiscal Model suggest a negative short-term impact on Canada real GDP of about 0.4 percent. ${ }^{2}$ The lower external demand weighs on exports, profits and disposable income, leading to permanently lower investment and private consumption. The Canadian dollar depreciates, softening the effect of the tariffs on exports, but increases the price of foreign goods. The trade balance deteriorates, then recovers as the exchange rate remains depreciated.

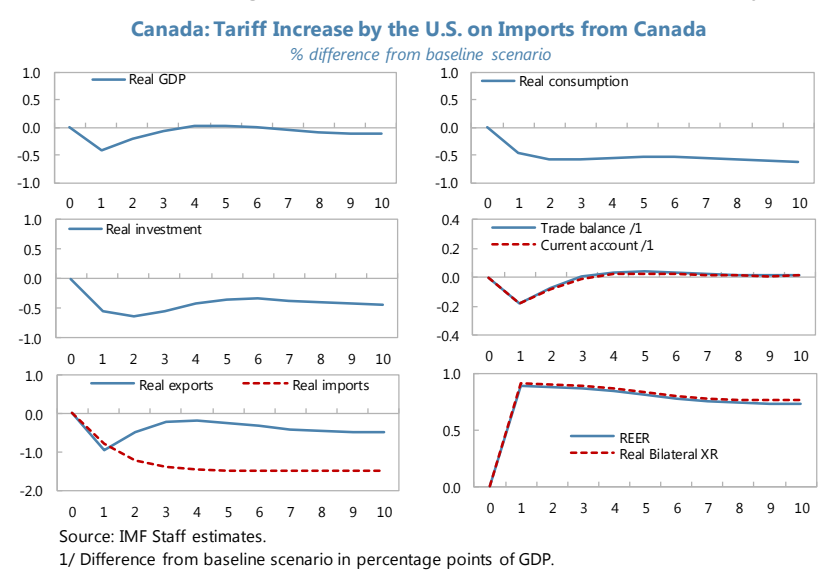

${ }^{1}$ The U.S. imposed tariffs ranging from 3 to 24 percent on Canadian softwood lumber exporting companies on April 25, 2017 , marking the fifth round in a dispute dating back to the 1980 s. The tariff increase affects about US $\$ 5.66$ billion worth of imports from Canada (CAN\$7.50 billion). This is 1.4 percent of Canadian exports of goods and 1.2 percent of total exports (goods and services) and 0.4 percent of 2016 GDP. Lumber accounted for less than 0.3 percent of all Canadian jobs in 2016. A 20 percent tariff on 1.4 percent of exports would yield about 0.3 percent average tariff on imports of goods from Canada. A companion antidumping duty investigation by the U.S. is still ongoing, with a preliminary determination expected June 23 , 2017.

2 The effects on the U.S. are negligible for GDP and moderately positive for private consumption, as the tariff revenues collected are rebated to households as transfers. The U.S. dollar appreciates, which partly offsets the higher prices of foreign goods. Households switch part of their consumption to domestic production, consistent with the decline in imports and exports. 


\section{POLICIES TO DEAL WITH GREATER UNCERTAINTY}

\section{A. Fiscal Policy}

22. Fiscal policy should continue to take the lead in supporting the recovery. The 2017 federal budget reaffirmed the government's commitment to this objective, proposing measures that are countercyclical, growth friendly, and inclusive. Overall, the discretionary measures are expected to contribute 0.6 percentage points to GDP growth in 2017.

- To smooth the economic cycle, the overall deficit will increase from 1.1 percent of GDP in FY2016/17 to 1.4 percent of GDP in FY2017/18, with infrastructure spending accounting for about 0.2 percent of GDP.

- To foster long-term growth, the budget will allocate about 0.4 percent of GDP over the medium-term to the Innovation and Skills plan, a new program designed to target growth and exports in six key areas: advanced manufacturing, agri-food, clean technology, digital industries, health/bio-sciences and clean resources.

- To promote inclusion, the budget includes Canada's first ever gender statement to make more inclusive decisions in the future and measures that expand caregiver support and parental leave to further improve female labor participation.

The discretionary measures will be funded through a reallocation of funds from existing projects and tax measures-that include a new tax on ride-sharing businesses ("Uber tax," currently not subject to the Goods and Services Tax), elimination of the public transit tax credit, and tighter control of tax evasion.

\section{No further stimulus will be required as the economy regains strength and the} output gap closes in 2018. In this regard, the cyclically adjusted federal deficit position should remain broadly unchanged in 2018 and gradually reduced beginning in 2019. This is broadly in line with the federal government's medium-term fiscal consolidation plan that will lower the overall deficit to 0.8 percent of GDP by FY2021/22.

\section{If downside risks were to materialize, additional fiscal stimulus should be} considered to support aggregate demand. Fiscal stimulus is more potent when there is slack in the economy and monetary policy is constrained by the effective lower bound. ${ }^{18}$ To ensure that fiscal policy can react quickly to unanticipated shocks, the authorities should have on stand-by stimulus measures that could be brought forward such as shovel-ready infrastructure and social housing projects, and temporary cuts of personal income taxes, which have a relatively high multiplier.

\footnotetext{
18 See Chapter 3, IMF World Economic Outlook, 2014.
} 


\section{Provincial governments need to be more cautious in their approach as they have a higher debt burden and growing health-care costs.}

- Among the Big-4 provinces, Ontario and Quebec are most indebted, and therefore, fiscal consolidation should continue, but only at a gradual pace so as not to offset the federal government's efforts to support the economy,

- In Alberta, with a sizable deficit (3.1 percent of Alberta GDP projected for FY2017/18), debt is expected to rise fast (albeit from a very low level). With its economy stabilizing, Alberta should formulate a fiscal consolidation plan that include measures to boost non-oil revenues (e.g., introduction of a goods and sales tax).

- An anticipated increase in health care costs due to population aging will constrain provincial finances. ${ }^{19}$ While the federal government is committed to increasing health-related transfers to provinces in line with nominal GDP growth or 3 percent (whichever is higher), provincial

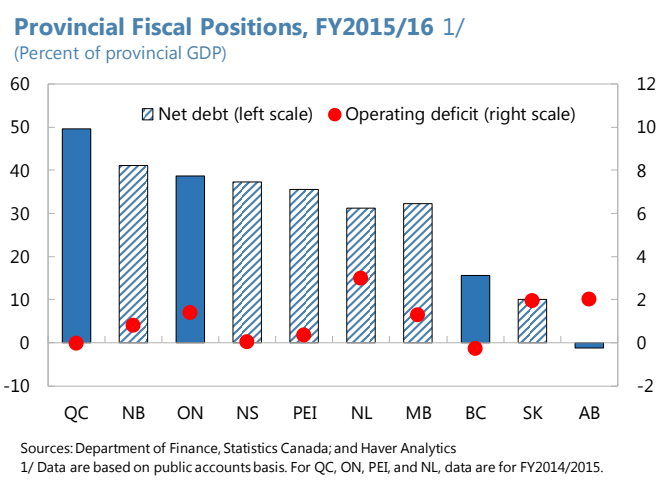
governments must manage the remaining fiscal gap.

\section{Infrastructure spending is a cornerstone of the government's growth strategy, and} if done right, will bring both short-term and long-term payoffs (Box 3). Canada has a highly efficient public investment framework and is thus well placed to implement the infrastructure program effectively. But there is room for improvement. Some public investment institutions involve multiple levels of government when executing complex infrastructure projects.

Consolidating existing information on project plans from all levels of government and expanding the use of common standards of analysis, and their publication, would improve the efficiency of public investment.

\section{The proposed Canada Infrastructure Bank (CIB), expected to be operational by late} 2017, will leverage private capital for public infrastructure. ${ }^{20}$ The CIB will handle large, complex, and revenue-generating projects, which would not otherwise be feasible, given that the risks involved are too large and the financial returns too small, to attract private investors while the cost is prohibitive for the federal government to go it alone (Box 4). It achieves this by

\footnotetext{
19 Provincial governments account for about 65 percent of total health expenditure, which is their single largest spending item. The federal government and social security funds pay about 5 percent, and the private sector (patients and insurers) pays the remaining of 30 percent.

20 See Selected Issues Paper "Leveraging Private Capital in the Public Interest", by D. Gentry and K. Ishi.
} 
attracting private capital up to the amount supported by user fees, and supplementing this amount with CIB investment. This lowers demand for budget financing and debt and frees up tax-payer money for other high priorities. The CIB differs in this respect from the P3 model, in which the government retains ownership of the asset and funds the project from the budget. The success of the CIB will depend on ensuring that the project selection process is transparent and balances public and private interests. Private investors will also be expected to bring their technical competence, discipline, and creativity that could help reduce risk and lower the overall project cost. Given the potential to boost productivity growth, the federal government should address public resistance to user fees and the involvement of the private sector in public infrastructure, with education and a clear statement of the CIB's benefits.

\section{The existence of a medium-term fiscal framework provides a good anchor for fiscal}

policy. The federal government is rightly committed to putting the debt-to-GDP ratio on a downward path over the next five years as it is important to rebuild buffers to fund future countercyclical policies: left unanchored, fiscal expansions could lead to higher risk premiums and funding costs for Canadian firms. Reinstating a new fiscal rule would be useful to support Canada's medium term fiscal framework, but it is reasonable to delay introducing a new fiscal rule until there is greater certainty that growth has stabilized around its potential. However, once this assessment is made, a clear timeline for introducing a new fiscal rule should be established. ${ }^{21}$ At the provincial level, fiscal rules should be strengthened to target the overall balance that includes capital spending, rather than the operational balance, so that a link between deficit and debt targets is clearly established.

${ }^{21}$ Possible options elaborated in the 2014 Article IV Staff Report remain valid. 


\section{Box 3. Infrastructure Investment}

Infrastructure need. Including ongoing projects, infrastructure investment would amount to Can $\$ 187$ billion ( $71 / 2$ percent of GDP). The government has identified public transit, green technology, trade, and social infrastructure as priority areas, with the aim of reducing congestion and commute time in urban areas, protecting the environment, facilitating trade, and improving social welfare (housing, child care, and indigenous communities, etc.).

Economic infrastructure refers to roads and other transportation facilities, power generation and other utilities, and communications systems. Transport networks connect producers and consumers to markets, utilities provide essential inputs such as power and water for both production and consumption, and communications networks facilitate the exchange and dissemination of information and knowledge. As such, infrastructure is an indispensable input in an economy's production.

Potential impact. Staff estimates suggest that a one dollar increase in the economic infrastructure stock would raise GDP by about 46 cents on average over the medium-term. ${ }^{1}$ Furthermore, the analysis finds some evidence of positive spillovers across provinces that could enhance the long-term growth effect.

${ }^{1}$ See Selected Issues Paper, "Estimating the Growth Effect of Infrastructure Spending," by K. Ishi, R. Mariscal and D. Gentry. 


\section{Box 4. Key Issues for the Proposed Canada Infrastructure Bank}

\section{Serving the public interest}

The CIB is intended to bring private capital to address public needs. The CIB project selection process must be designed to ensure that high priority public needs are met. CIB will seek interested private investors for the short-listed projects. Cabinet could have authority to veto CIB proposed projects to ensure accountability for the use of taxpayer funds. The criteria for selecting projects should be published.

\section{Attracting private capital}

Private investors will invest only if they expect to receive what they believe to be an acceptable risk-adjusted rate of return. The CIB's role is to structure financing that is attractive to private investors. To achieve this result, CIB can: (i) increase cash inflow (revenue) primarily by incorporating user fees into the project financing arrangement; (ii) reduce cash outflows (costs) by building on private sector expertise and discipline; and iii) reduce risk premium, the most important of

A private investor would be willing to invest ("buy") an amount equal to the present value of the future free cash flows of a project - the present value will rise if the future free cash flows increase or if the risk premium becomes smaller.

$$
\sum_{t=0}^{N} \frac{(\text { future value })_{t}}{(1+\text { risk free rate }+ \text { risk premium })^{t}}
$$
which is revenue risk. Taken together, these actions will increase the amount of leveraged capital. In addition, private investors can lower the upfront total project cost by applying experience gained in other similar projects.

\section{Fiscal impact}

The CIB will be authorized to spend $\$ 35$ billion in amounts that will be provided by the Minister of Finance as needed, of which $\$ 15$ billion could be used as "first loss" equity to attract private capital. A corporate plan along with an operating and capital budget will be prepared annually, and submitted for approval as designated in law. Private capital reduces the need for government to provide budget finance or to borrow for infrastructure. Fiscal risks appear contained, as issuance of guarantees by the CIB requires approval by the Minister of Finance and the special purpose vehicle created to implement the project will protect the government's balance sheet by limiting any liabilities or losses to CIB's equity investment.

\section{Public acceptance}

Public acceptance of the CIB's basic strategy is a precondition to its success. The government and the CIB must make a concerted effort to enhance public understanding of the need to involve private investors, and the need to offer them adequate returns, if public infrastructure is to be expanded with minimal fiscal impact. Publication of the selection criteria for projects and investors, and a competitive selection of investors will give the public confidence that public interest is being served at the least cost. 


\section{B. Monetary Policy}

29. The current monetary policy stance is appropriate. The policy rate has been on hold at 0.5 percent since July 2015 (Figure 7). Staff model-based estimates of the neutral rate of interest suggest that monetary policy remains accommodative, with the actual policy rate below the estimated neutral rate..$^{22}$

30. While the output gap has started to close, monetary policy should stay accommodative until signs of durable growth and higher inflation emerge. After several years of low growth, Canada's economic activity remains fragile and the uncertainty around the economic outlook is considerable. Monetary policy normalization, therefore, needs to be approached cautiously. Given downside risks and a policy rate close to zero, deferring rate increases and allowing a temporary overshoot above the inflation target would be appropriate and reinforce the symmetry of the inflation target. This would provide insurance against the risks of disinflation and policy reversal. If the baseline evolves in line with staff's forecasts, and barring upside surprises to growth or inflation, such a policy would imply keeping the policy at 0.5 percent into the first half of 2018 with a gradual rise thereafter.

31. If the economy slows down, a further easing of monetary policy could be a useful complement to fiscal stimulus, but there is a risk that it could worsen imbalances in the housing sector. However, a further cut in the policy rate or recourse to unconventional measures could become necessary if significant downside risks were to materialize and staving off a recession becomes priority. The $\mathrm{BOC}$ estimated that the effective lower bound for the policy rate is -0.5 percent. If the yield curve steepens sharply, it would be appropriate to use forward guidance to reduce long-term rates. Clear communication would be critical.

\section{Financial Sector Policy}

32. Since 2008, the federal government has gradually tightened macroprudential policy to reduce its exposure to mortgage insurance and to contain vulnerabilities in the housing sector, in line with past Fund recommendations (see Annex III for a full list of measures). Staff's research indicates that the various rounds of macroprudential measures have generally been effective in slowing the growth in mortgage credit and, to a lesser extent, house prices, and

\footnotetext{
22 The neutral interest rate is estimated using a new-Keynesian model. For the model structure see M. Obstfeld et al. "How to Improve Inflation Targeting in Canada" IMF Working Paper WP/16/192, 2016.
} 
to this end financial stability. ${ }^{23}$ The October 2016 measures that imposed stricter qualification rule for insured mortgages has reduced high-ratio mortgage originations by 12 percent year on year in the first quarter of 2017. OSFI is assessing the impact of the newly introduced risksensitive floor for loss given default for mortgages. ${ }^{24}$

33. Nevertheless, rising housing imbalances call for more targeted measures to address excessive speculation in all mortgages. Tackling housing market imbalances should be a joint responsibility of both the federal and provincial authorities given the regional divide in housing imbalances. While the authorities have been pro-active in tightening mortgage insurance rules and credit underwriting standards, the high level of household debt and the exposure of the banking system warrant a further tightening of macroprudential and tax-based measures to mitigate speculative and investment activity. A combination of measures could work for both insured and uninsured mortgages:25 ${ }^{26}$ caps on LTI or LTVs; a cap on the share of mortgages with high LTI in bank portfolios; ${ }^{27}$ more stringent stress test on mortgage rates (e.g. 300 basis points), with a higher spread for high LTI loans; and a higher property transfer tax on properties sold within a relatively short period or bought for investment purposes; or an empty home tax. Among these measures, LTI-based measures would strengthen household balance sheet resilience and reduce the probability of household defaults under downside risk scenarios.

\section{Recent measures announced by British Columbia and Ontario could also help} reduce housing market imbalances, but the property transfer tax on non-residents could be replaced with alternative measures. While the tax is targeted and transparent, and the authorities' concerns about affordability are valid, the tax amounts to a capital flow management measure because it discriminates between residents and non-residents and limits capital flows. Staff recommends alternative measures as discussed above that are consistent with the IMF's Institutional View on the Liberalization and Management of Capital Flows and that can effectively address both financial stability and affordability concerns.

\section{For macroprudential policy to work effectively, more granular real estate data and close supervision to manage potential spillovers and other unintended consequences are needed. Comprehensive and timely data on real estate transactions, including foreign investors'}

\footnotetext{
23 See Selected Issues Papers, "Macroprudential Tools at Work in Canada", by Z. Arvai, I. Krznar, and Y. Ustyugova, and "How Some Advanced Economies Tackled Housing Imbalances: Lessons for Canada" by Z. Arvai and Y. Ustyugova.

${ }^{24}$ In addition to demand management measures, the Ontario government is exploring ways to use provincially owned surplus lands for affordable and rental housing to increase the supply of housing.

${ }^{25}$ LTIs were not tested because of a small sample size but the results show LTVs as among the most effective tools both in Canada and internationally. In Canada, the estimates indicate that a one percentage point reduction in both the maximum LTV for new mortgages and for refinancing loans would reduce year-on-year mortgage credit growth by about 0.5 percentage points.

${ }^{26}$ See cross-country examples of these measures in the Selected Issues Paper "How some Advanced Countries Tackle Housing Market Imbalances" by Z. Arvai and Y. Ustyugova

27 The U.K. has a restriction that mortgage lenders cannot extend more than 15 percent of their total number of new residential mortgages at LTI ratios at or greater than 4.5.
} 
activity in the property market, would be important to inform surveillance, track systemic risk outside the insured mortgage sector or in the shadow banking system, and better calibrate macroprudential measures in terms of size and coverage. As such, the allocation in the 2017 budget of Can $\$ 40$ million over five years for Statistics Canada to develop a national database of residential transactions is a step in the right direction. Furthermore, given the regional divide in housing markets, close coordination between federal and provincial authorities is critical for surveillance and resolving emerging problems in a timely fashion. OSFI is in the process of strengthening their credit underwriting guidelines: while provincially regulated financial institutions (e.g., credit unions) are not subject to these guidelines, unless the mortgages are federally-insured, they should be encouraged to adhere to OSFI's underwriting standards for mortgages.

36. In addition, addressing gaps identified in the 2014 FSAP would further strengthen the framework for financial sector policy (Annex V):

- Clear and explicit regulatory mandates to monitor systemic risk and to facilitate macroprudential oversight and carry out system-wide crisis preparedness.

- Consistent with Basel Core Principles, legislation should be amended to give OSFI operational independence without ministerial power to override supervisory judgment.

\section{If housing markets start correcting much faster than expected and raise financial} stability concerns, the authorities may need to consider easing macroprudential measures. Macroprudential policy needs to be calibrated carefully, tight enough to reduce housing imbalances, but not so tight, that it triggers a disruptive adjustment.

\section{Addressing the shortcomings identified in Canada's AML/CFT assessment should} help mitigate money laundering risks in the real estate sector (see Annex IV). The 2015 IMF assessment against the FATF standards found that Canada has a strong AML/CFT regime, achieving good results in some areas, but requiring further improvements to be fully effective. The real estate sector was found highly vulnerable to money laundering, due to its exposure to high-risk clients, including politically exposed persons and foreign investors. Accordingly, the assessment called for strengthening supervisory measures in the real estate sector, and requiring all professionals involved in real estate sector transactions (including legal counsels, legal firms and Quebec notaries) to fall within the AML/CFT framework and to implement relevant due diligence measures regarding beneficial owners of assets and politically exposed persons. 


\section{Trade and Structural Reforms}

39. Revitalizing productivity and finding new export markets will be key to create jobs for the middle class over the medium

term. Staff research and other studies have shown that reducing barriers to product market competition, ${ }^{28}$ improving the innovation framework, increasing access to post-secondary education, and active labor market policies, bring sizable productivity gains that could help reverse the declining trend in Canada's long-term growth.

\begin{tabular}{|c|c|c|}
\hline \multicolumn{3}{|c|}{ Impact of Product Market Reform } \\
\hline & Type of reform & GDP level effects \\
\hline $\operatorname{IMF}(2016)^{1 /}$ & $\begin{array}{l}\text { Major legislative/regulatory } \\
\text { reform in network industries }\end{array}$ & $\begin{array}{l}\text { About } 1.5 \text { percent of GDP } \\
4 \text { years after the reform }\end{array}$ \\
\hline Lukas A. and T. Trevor (2016) ${ }^{2 /}$ & $\begin{array}{l}\text { Eliminating all barriers to } \\
\text { inter-provincial trade }\end{array}$ & 3-7 percent of GDP. \\
\hline $\begin{array}{l}\text { Standing Senate Committee on } \\
\text { Banking, Trade, and Commerce }\end{array}$ & Same as above & $\begin{array}{l}0.05-7 \text { percent of GDP } \\
\text { (survey of studies by } \\
\text { academia and think tanks) }\end{array}$ \\
\hline \multicolumn{3}{|c|}{$\begin{array}{l}\text { 1/ "Time for a Supply-side Boost? Macroeconomic Effects of Labor and Product Market Reforms } \\
\text { in Advanced Economies," IMF April } 2016 \text { WEO Chapter } 3 .\end{array}$} \\
\hline \multicolumn{3}{|c|}{$\begin{array}{l}\text { 2/ "Internal Trade, Productivity, and Interconnected Industries: A quantitative Analysis," } \\
\text { Canadian Journal of Economics, Vol 49, Issue } 1 .\end{array}$} \\
\hline \multicolumn{3}{|c|}{ 3/ "Tear Down These Walls: Dismantling Canada's Internal Trade Barriers," June 2016.} \\
\hline
\end{tabular}

\section{The authorities have taken a historic} step forward in reducing barriers to internal trade, investment, and labor mobility. ${ }^{29}$ In April 2017, the federal and provincial governments signed a new Canadian Free Trade Agreement (CFTA) that will move interprovincial trade to a 'negative list' approach, harmonize regulations and standards, and improve government procurement rules to level the playing field for Canadian businesses bidding for government contracts. The devil, nevertheless, is in the details and much work remains to make the CFTA as broad as possible, notably by

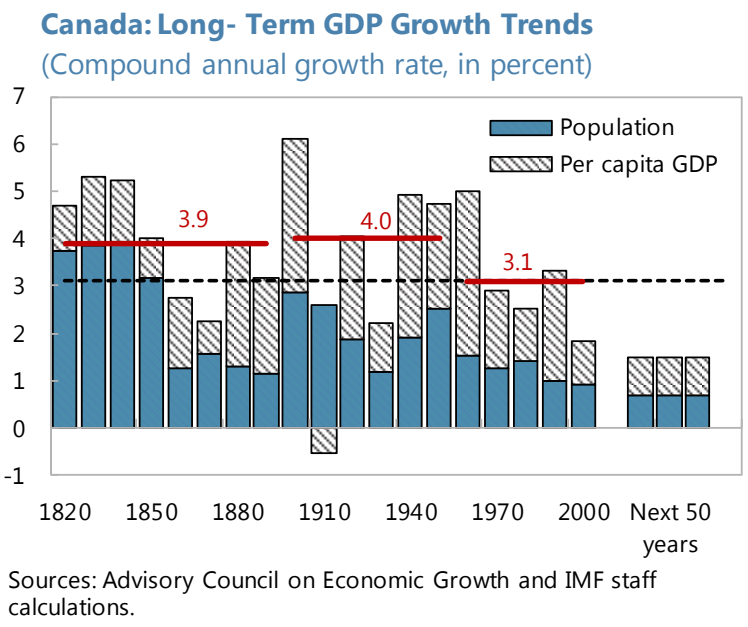

\footnotetext{
${ }^{28}$ Also, see cross-industry evidence for network industries in Bouis-Duval-Eugster, "Product Market Deregulation and Growth: New Country-Industry-Level Evidence", IMF Working Paper WP/16/114, 2016; Duval-Furceri, 2016 ARC Conference paper "The Effects of Labor and Product Market Reforms: The Role of Macroeconomic Conditions and Policies"; and for firm-level evidence in Gal-Hijzen, "The Short-Term Impact of Product Market Reforms: A Cross-Country Firm-Level Analysis", IMF Working Paper WP/16/116, 2016.

${ }^{29}$ It is estimated that 40 percent of the total value of provincial and territorial exports are destined for interprovincial trade partners rather than for other countries. These internal exports represent 20 percent of Canada's GDP. The BOC estimates that removing interprovincial barriers could raise Canada's potential output growth by around 0.2 percentage points annually. See also OECD "Strengthening Competition in Network Sectors and the Internal Market in Canada", 2016.
} 
including energy, address the distortionary agricultural supply management regimes, ${ }^{30}$ and establish a pan-Canadian council to harmonize legislation and regulations. ${ }^{31}$

\section{Furthermore, the government unveiled an ambitious "Innovation and Skills Plan" in} the $\mathbf{2 0 1 7}$ budget, drawing on an extensive study by the Advisory Council on Economic Growth. ${ }^{32}$ The plan proposes measures to enhance innovation, upgrade labor skills, and empower women in the workplace, supported by a budgetary allocation of Can $\$ 8$ billion ( 0.4 percent of GDP) over the next five years (Annex VI).

- A new platform, Innovation Canada, will coordinate and simplify the support available to Canada's innovators, including by identifying sector-specific challenges and "bottlenecks" to commercialize innovation and scale up start-up businesses. Up to Can $\$ 950$ million will be provided on a competitive basis to "superclusters" that have the greatest potential to accelerate economic growth, by focusing on highly innovative industries such as advanced manufacturing, agri-food, clean technology, digital technology, health/bio-sciences and clean resources, as well as infrastructure and transportation.

- Invest in education and research, including lifelong learning programs to help working adults upgrade their skills, a Youth Employment Strategy to create job opportunities for young Canadians, and targeted immigration to attract top talent to Canada (Box 5). A new entity will be established to work with stakeholders, including provincial authorities and educational institutions, to (i) identify skills needed and sought by employers, (ii) explore new and innovative approaches to skills development; and (iii) share information and analysis.

- Provide more flexible family benefits and work arrangements to encourage women to enter and stay in the workforce (Box 6).

\section{The government's reform priorities are comprehensive and consistent with Fund and OECD advice, and the challenge now is to make them work. In Canada, since policy} responsibility is shared by different levels of governments, concerted coordination across all jurisdictions will be necessary to reduce overlaps, competing objectives, and inefficiencies that arise from operating too many programs at too small a scale. The federal authorities should take the lead in coordinating innovation policies, establish uniform metrics of success, and institute a

${ }^{30}$ Canada's dairy sector is regulated through a domestic system of supply management that operates through: production controls, price controls (according to the OECD, milk prices received by Canadian farmers were, on average, 7 percent higher in 2013-15 than those observed in world markets), and import controls (a system of "tariff-rate quotas" allows a fixed volume of imports at low tariff rates, but the marginal tariff rates for imports above the quotas are prohibitively very high). The latter has become an important trade irritant between the US and Canada and is likely to get attention during the NAFTA renegotiation.

31 See Chapter 3, "Economic Policy Reforms 2017: Going For Growth," in OECD 2017.

32 The Minister of Finance established the Advisory Council on Economic Growth in March 2016. The council comprises 14 members (of which 8 are women), including Canadian and international business, finance executives, and academia, and is chaired by Dominic Barton, Global Managing Director of McKinsey \& Company. 
transparent and regular reporting mechanism to monitor progress. Over time, the authorities should adjust the policy mix to ensure that public resources are being used efficiently.

43. Policies to promote innovation should be transparent and well targeted. Direct support of R\&D through investment in basic scientific research which firms are unlikely to undertake (public universities, government research institutes, and defense-related research) or providing financing or fiscal incentives to lower the private cost of R\&D can help correct the structural underinvestment in R\&D. The fiscal incentives can take the form of tax credits and direct subsidies (through loans or grants; or guaranteed loans), both of which can be effective. Two caveats should be kept in mind:

- R\&D incentives to small firms tend to be two to three times more effective in Canada than for large firms in generating extra private $R \& D .{ }^{33}$ However, $R \& D$ incentives to large firms can be desirable too, since the spillovers of additional $R \& D$ activities on other firms are typically larger than those from small firms. Specific $R \& D$ incentives might also be targeted to new firms that suffer relatively more from credit constraints.

- Policies to promote innovation, including through the superclusters initiative, should not choose winners and losers but create a "competition-friendly" business environment. Interventions targeted to sectors with high-knowledge spillovers between firms (which are hard to identify a priori) can support innovation and productivity growth provided they meet several conditions, including, providing support to high-spillover sectors only insofar as these are competitive, spreading the support across many firms, and finding ways for new entrants (not just incumbents) to also potentially benefit from such support. ${ }^{34}$

44. The time is right to launch a holistic review of the overall tax system to improve the efficiency of the tax system and preserve Canada's tax competitiveness with the rest of the world. The tax system has become increasingly complex with a myriad of tax credits, deductions, and exemptions. The last comprehensive review was conducted in the mid-1980s and changes since 2000 have been iterative rather than comprehensive. ${ }^{35}$ Specifically, the federal corporate income tax rate was cut almost in half between 2000 and 2012 and some tax preferences were eliminated, but a number of tax preferences for small businesses, Atlantic Canada, mining and manufacturing were maintained and in some instances enriched. Comprehensive reform of the tax system is needed to support the structural transformation of the economy, demographic shifts, adoption of new technologies, climate change, and provincial fiscal sustainability. The review should examine all aspects of the tax system, including taxes on earnings, savings,

\footnotetext{
33 IMF, Fiscal Monitor April 2016 and 2017, and OECD: "Lessons from Financing Young Innovative Firms", 2015.

34 See Aghion, P. et al, 2015, "Industrial Policy and Competition," American Economic Journal: Macroeconomics, 7(4):1-32; and Agion-Boulanger-Cohen "Rethinking Industrial Policy," Brugel Policy Brief, June 2011.

${ }^{35}$ A major reform of federal income tax took place in the late 1960s (Carter Commission), culminating in the new Income Tax Act that became effective January 1, 1972. Two major reforms came out of the review of the mid1980s, one in 1987 that reduced the number of personal income tax brackets from nine to three and the 1991 introduction of the goods and services tax (GST) to replace a cascading federal sales tax. See also R. Broadway, "Policy Forum: Piecemeal Tax Reform Ideas for Canada-Lessons from Principles and Practice", Canadian Tax Journal (2014) 62:4, 1029-59.
} 
consumption, businesses, and housing, and cover both federal and provincial taxes. It would help assess whether there is scope for reducing distortions, minimizing administration and compliance costs, and enhancing equity, while generating sufficient revenues to cover government spending. A simpler and more efficient tax system is important to encourage labor force participation, improve the productivity of business investment, and promote innovation.

\section{Less progress has been made in reducing FDI restrictions in key sectors of the} economy, Canada is one of the easiest countries in which to establish a business-like domestic investors, foreign investors may incorporate a company in only one day-but it has greater restrictions on foreign investment (ownership) than other high-income OECD countries, including licensing requirements in retail sectors, and discrimination against foreign suppliers in professional services, air and road transport. Non-Canadians cannot own a controlling share in telecommunications, broadcasting and transportation sectors. ${ }^{36}$ Reducing foreign ownership restrictions and improving the regulatory environment in these sectors would lower prices, speed-up the adoption of new technologies, increase competition, and align supply and demand in real time that are crucial for expanding exports of services and high value informationintensive goods.



46. Canada's geographic proximity to the U.S. and Mexico will mean that NAFTA trade will continue to be important, but diversifying its export markets will bring new sources of growth. The Canada-EU Comprehensive Economic and Trade Agreement (CETA) agreement is a major step forward in establishing new trade relationships. The agreement was signed in October 2016 and applied provisionally starting in mid-2017, and is expected to boost bilateral trade between Canada and the EU by 20 percent from the current share in total trade of 5.6 percent. ${ }^{37}$ Canada should also pursue new sources of growth in Asia, including with China, India and Japan, which collectively account for 6.9 percent of Canada's total exports.

\footnotetext{
${ }^{36}$ In May 2017, the government tabled legislation proposing to amend the Canada Transportation Act (i) to liberalize international ownership restrictions from 25 to 49 percent of voting interests for Canadian air carriers; and (ii) to lift ownership limits for Canadian National Railway Co. from 15 to 25 percent.

37 "Assessing the Costs and Benefits of a Closer EU-Canada Economic Partnership", a joint study by the European Commission and the Government of Canada, 2008.
} 


\section{Box 5. A Talent-Based Immigration Policy}

Immigration has been an important driver of population and labor force growth in Canada. Today about one fifth of the population in Canada is foreign born (sixth highest in the OECD), and newly arrived immigrants account for more than 50 percent of annual population growth. Between 1990 and 2015, immigrants contributed more than a third to the growth in Canada's working-age population in Canada.

Managed and targeted migration is a hallmark of Canada's approach to immigration. Canada's immigration system has long targeted high-skilled immigrants, rewarding education, fluency in English or French, and work experience. About half of immigrants hold a university degree, compared to just 21 percent of the Canadian-born population. The newcomers benefit from settlement services, long-term language support and bridging/recognition procedures that promote rapid labor market integration and a common sense of belonging. Contribution of Migrants to Population
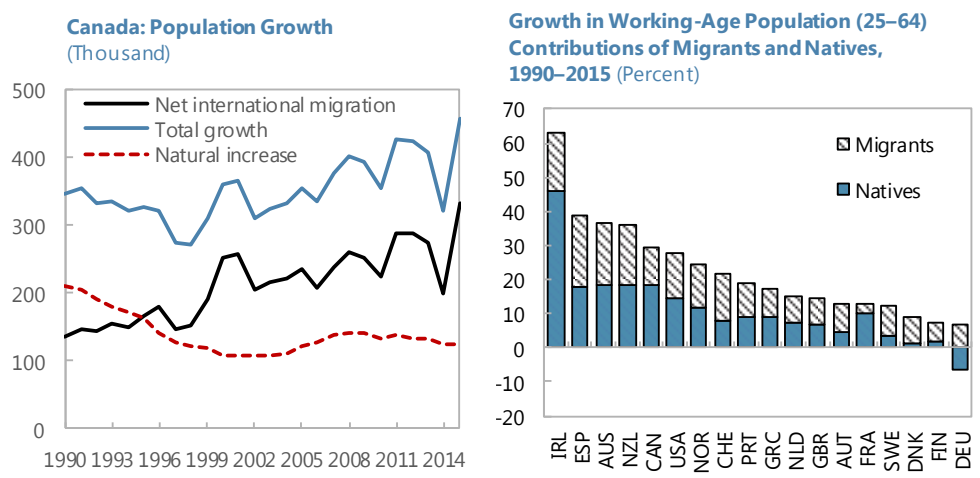

Sources: CANSIM Table 051-0004, United Nations, World Population Prospects, The 2015 Revision; and Jaumotte, Koloskova, Saxena (2016). Note: Data labels in the figure use Intemational Organization for Standardization (ISO) country codes.

Going forward, the role of immigration in maintaining a sustainable demographic structure is important due to population aging. In the absence of immigration, the working age population in Canada will drop by 8 percent within 10-15 years, while the share of the population over the age of 64 would rise from 16 percent in 2015 to 23 percent in $2030 .^{1}$ Without policy action to offset the impact of these demographic changes, annual GDP growth over the next 50 years could drop by more than half of historical levels to 1.5 percent and per capita GDP growth could decline to 0.8 percent. ${ }^{2}$ Jaumotte et al $(2016)^{3}$ estimate that a 1 percentage point increase in the share of migrants in the working-age population can raise GDP per capita over the long term by up to 2 percent regardless of the skill level of migrants, possibly because most migrants tend to be "over-qualified".

${ }^{1}$ Ades. J, D. Fields, A. Macdonald, and M. Stewart. "A Long-Term View of Canada's Changing Demographics: Are Higher Immigration Levels an Appropriate Response to Canada's Aging Population?" The Conference Board of Canada, October 2016.

2 "Attracting the Talent Canada Needs through Immigration", Advisory Council on Economic Growth, October 2016.

3 Jaumotte, Florence, Ksenia Koloskova, and Sweta C. Saxena 2016. "Impact of Migration on Income Levels in Advanced Economies." Spillover Note 8, International Monetary Fund, Washington.

\begin{tabular}{|c|c|}
\hline \multicolumn{2}{|r|}{ Canada: Immigration By the Numbers } \\
\hline 1 in 5 & Canadians born outside Canada \\
\hline 31,462 & Refugees admitted in 2015 \\
\hline 271,369 & Permanent residents admitted in 2015 \\
\hline 3.7 million & New permanent residents in the last 15 years \\
\hline $\begin{array}{l}\$ 953 \text { million } \\
(0.05 \% \text { of GDP) }\end{array}$ & Spending on settlement funding for 2016-17 \\
\hline 15 million & Immigrants since Confederation \\
\hline 35.8 million & Canada population in 2015 \\
\hline
\end{tabular}
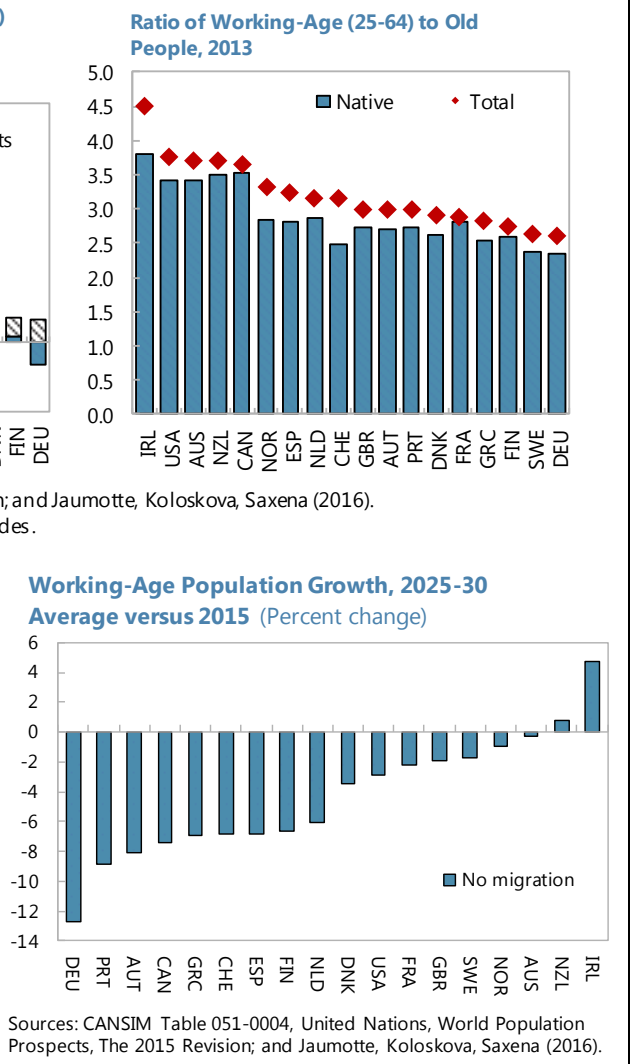

Working-Age Population Growth, 2025-30 Average versus 2015 (Percent change)



Sources: CANSIM Table 051-0004, United Nations, World Population Sources: CANSIM Table 051-0004, United Nations, World Population
Prospects, The 2015 Revision; and Jaumotte, Koloskova, Saxena (2016).

CANADA 


\section{Box 6. Gender Budget}

Canada published its first ever gender statement in the 2017 federal budget, as part of the government's ongoing efforts to achieve gender equality over medium term. The statement includes the assessment of gender gaps and a gender-based analysis of budget measures.

\section{Gender gaps remain substantial}

Canada has made a grade stride in raising female labor participation rates and education attainment over the past several decades. Today, both indicators fare relatively well compared to other OECD economies.

However, career-related gender indicators show gaps. Women's median wage in Canada is about 19 percentage points lower than men's (compared to the OECD average of 15 percentage points), while women remain substantially underrepresented in private sector executive boards and national parliaments, well below the best OECD economy.

A forthcoming study by the IMF suggests that a 1 percentage point increase in the labor force participation of women with an advanced degree would raise Canada's overall labor productivity growth by 0.2 to 0.3 percentage point a year. So, if the current gap of 7 percentage points between male and female labor force participation were eliminated, the level of real GDP could be about 4 percent higher today. ${ }^{1}$

\section{Key gender measures}

The gender statement proposes more than 60 measures to address gender gaps; they include the Canada Child Benefit, a tax-free monthly benefit that helps parents with child care costs; new investment in early learning and child care (e.g., creating 40,000 new subsidized childcare spaces) to give parents more choices when it comes to participation in work, education or training; new funding to promote the development of STEM skills and digital literacy, particularly for women, girls and underrepresented groups; expanding employment insurance caregiver benefits to care for critically ill or injured family members; and updating the Canada Labor Code to give federally regulated employees more flexible work arrangements.

${ }^{1}$ See "Women and Key for Future Growth: Evidence from Canada," by Bengt Petersson, Rodrigo Mariscal, and Kotaro Ishi (IMF WP, forthcoming). 


\section{AUTHORITIES' VIEWS}

\section{The authorities broadly agree with staff's assessment of macroeconomic} developments. The authorities see growth accelerating to around $2 \frac{1}{2} 2$ percent in 2017 as the economy's adjustment to lower oil prices is largely complete. A temporary surge in growth in the first quarter, however, is likely to moderate in the second quarter. Consumer spending is expected to continue to be robust on the back of an improving labor market and strong housing sector, and recent indicators of business investment suggest growth is likely to turn positive. Export growth, however, could remain subdued in the face of ongoing competitiveness challenges. Over the medium-term, the authorities expect labor force growth and hence potential output growth to slow, owing to population ageing.

48. The authorities consider risks around the outlook to be roughly balanced. The prospect of a notable shift toward protectionist global trade policies is the most important source of policy uncertainty surrounding the outlook, as the range of possible outcomes is wide, and the channels through which the protectionist measures would affect the economy are complex. On the upside, faster than expected U.S. growth would increase demand for Canadian exports. Domestic risks include a house price correction in overheated markets, as elevated debt makes households vulnerable to shocks, and sluggish business investment for an extended period would lower potential output.

\section{The authorities agree that monetary and fiscal stimulus could be gradually} withdrawn, as the output gap closes and the economic expansion becomes increasingly self-sustaining. They also agree that fiscal policy should be the first line of defense if downside risks were to materialize. Nonetheless, if the size of a negative shock is very large, both monetary and fiscal policy would be fully deployed. The Bank of Canada noted that the policy rate can be cut by 100 basis points before hitting the effective lower bound. For the time being, monetary policy has stayed accommodative given the lack of inflation and wage pressures.

50. The authorities are actively engaging with key stakeholders to make a compelling case for the proposed CIB as an important new tool to promote long-term growth and support the creation of good, well-paying jobs for the middle class. They agree that, by using government support to attract private sector and institutional investment to revenuegenerating infrastructure, where investors receive a risk-adjusted commercial return for bearing the risk of the revenue business model, more infrastructure would be built, but this will require a fostering of public acceptance. The authorities plan to demonstrate the benefit of the CIB by highlighting the size of the infrastructure gap and the challenges for governments to bridge this gap through fiscal resources only; and by actively seeking opportunities to communicate the merits of the CIB to a broader audience.

51. The authorities are closely monitoring the situation in the housing sector. They noted that recent macroprudential and other policy measures have already contributed to more sustainable debt profiles of high-ratio mortgages and further salutary effects are expected. The 
authorities emphasized that the problem at Home Capital was an isolated event due to concerns regarding the firm's governance and management, and that the banking system overall is sound and well capitalized. The market reaction to the Moody's downgrade of the six large banks was modest and had little impact on long-term funding costs or mortgage rates. Canadian banks' credit ratings remain broadly equal to or higher than most global banks, including those in the U.S., the Euro Area, and Australia.

\section{The authorities do not agree with the staff's characterization of provincial non-} resident property transfer taxes. These measures were not introduced to target capital flows, and their effect on aggregate capital flows was likely minimal, given Canada's high degree of capital account openness. Rather, following the implementation of similar measures in certain other countries with rapidly rising house prices, they were introduced in two specific urban areas to help address excessive demand for housing, including from foreign investors, that was negatively affecting affordability for Canadian homebuyers. Early data suggest that the announcement of these measures had some cooling effect on house prices. Canada's housing market conditions remain highly differentiated across regions and provincial governments are responsible for their own tax and other policies to address such conditions. The authorities also noted that the federal, provincial and municipal governments are working collaboratively regarding housing issues in Vancouver and Toronto, including by addressing data gaps and supporting the proper functioning of the housing market.

\section{Flagship innovation programs have been designed to focus resources without} having the government pre-determine "winners". The superclusters initiative is designed to be an open competition where proposals will be assessed against desired economic outcomes of increasing productivity and competitiveness. In addition, the six Economics Strategy Tables are intended to promote a dialogue between the private sector and the federal government to identify barriers and establish growth targets. The Tables do not have funding to disburse. On the tax side, the Scientific Research and Experiment Development (SR\&ED) tax incentive program offers broad-based support for SR\&ED performed in Canada. Being available to all businesses in every industry sector in Canada, the SR\&ED program does not aim to pick winners and losers. As such, the incentive is designed to support a broad range of $R \& D$ activities in order to promote a level-playing field and competitive environment for all businesses to innovate.

\section{STAFF APPRAISAL}

54. Three years after the oil shock, the Canadian economy has turned the corner. The cyclical recovery is underway and, if growth continues in the current trajectory, the output gap will close by mid-2018, earlier than originally envisaged. A stronger than expected U.S. growth would provide further upside. The recovery, however, is skewed to consumption, with business investment and non-energy exports remaining weak. This raises questions about the sustainability of the recovery at a time when the economic outlook is subject to significant risks in the housing market and uncertainty about U.S. policies on trade and tax reform. 
55. Fiscal policy should be geared toward ensuring that the cyclical recovery is secure and inclusive. The fiscal stance should remain expansionary this year. As the output gap closes, no further increase in the deficit resulting from discretionary spending or tax cuts will be required, consistent with the government's medium-term fiscal plan. If downside risks were to materialize, additional fiscal stimulus should be the first line of defense, as Canada has some fiscal space. Fiscal consolidation at the provincial level should continue but at a gradual pace.

56. Monetary policy should stay accommodative and gradually tightened as signs of durable growth and inflation pressures emerge. The Bank of Canada's cautious approach is justifiable given the considerable uncertainty around the economic outlook. If the economy slows down, a further cut in the policy rate could complement fiscal stimulus but this could exacerbate housing imbalances. Monetary easing or recourse to unconventional measures may, however, become necessary if there is a significant contraction in economic activity.

57. Maintaining fiscal discipline over the medium-term will be important to keep funding costs low and to rebuild buffers. The government's commitment to set debt-to-GDP on a declining path is welcome. Once the economy stabilizes around its potential, reinstating a fiscal rule to anchor the medium-term fiscal framework would help ensure the sustainability of public finances. A credible medium-term consolidation plan will help improve the external position, which currently is moderately weaker than implied by fundamentals and desirable policies.

58. Infrastructure investment is central to the fiscal strategy to foster long-term growth and the proposed CIB will be an effective instrument to achieve this goal. The success of the CIB will depend on ensuring that the project selection process is transparent and balances public and private interests. A clear statement of the CIB's benefit could help persuade the public of the need for user fees, revenues that are essential to reflect the transfer of risks to private investors.

59. Macroprudential policy needs to protect the resilience of the household and banking sector. Both the federal and provincial authorities should consider a further tightening of macroprudential and tax-based measures to mitigate speculative and investment activity. A cap on household debt relative to income or more stringent qualification criteria above a debt threshold would go directly to addressing household indebtedness. Government efforts to collect more comprehensive data on real estate transactions would improve surveillance and the calibration of macroprudential measures. Consistent with the Fund's Institutional View on capital flows, provincial authorities are encouraged to replace the property transfer tax with alternative measures that effectively address financial stability and affordability concerns without discriminating between residents and non-residents, or targeting capital flows.

60. The government recognizes that revitalizing productivity is key to placing Canada on a higher and sustainable growth path over the medium term. Structural reform policies should be transparent and well targeted, with the aim of creating an "innovation- and competition-friendly" business environment, and implemented with close coordination between 
federal and provincial authorities. To support the structural transformation of the economy a holistic review of the overall tax system would be warranted to help assess the scope for improving the efficiency of the tax system, while maintaining Canada's tax competitiveness. Finally, more can be done to reduce FDI restrictions and regulatory barriers to entry in key sectors of the economy.

\section{Diversifying Canada's export markets will facilitate its integration into global} supply chains and reduce its dependence on the U.S. market. The CETA agreement with the EU is a major step forward in establishing new trade relationships. Canada should also pursue closer trade integration with Asia.

62. It is recommended that the next Article IV consultation take place on the standard 12-month cycle. 


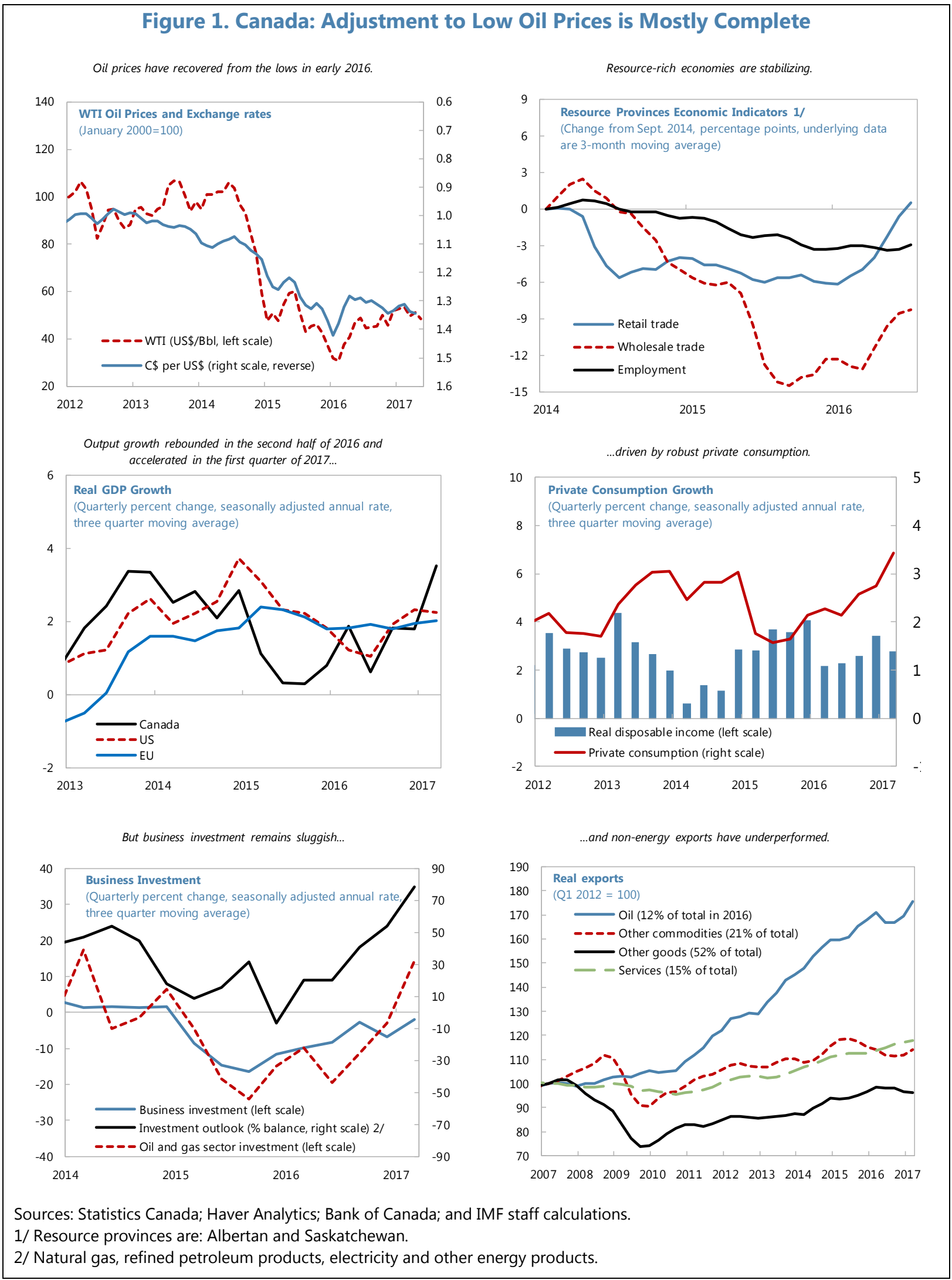


Figure 2. Canada's Labor Market has Shown Resilience

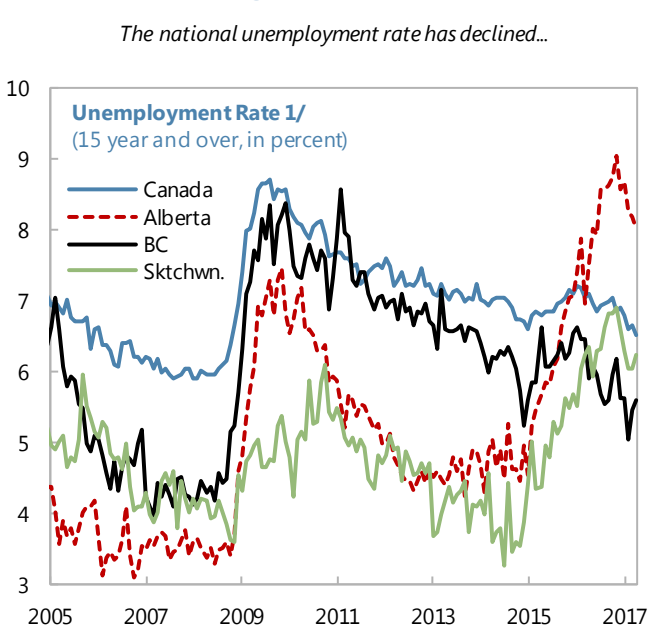

... and interprovincial migration to the non-resource provinces has slowed.

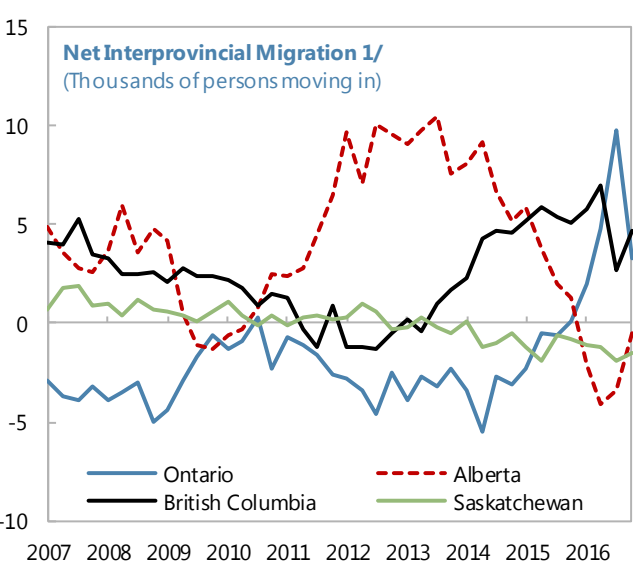

Employment growth is driven by the service sector...

...with net gains in full-time jobs...
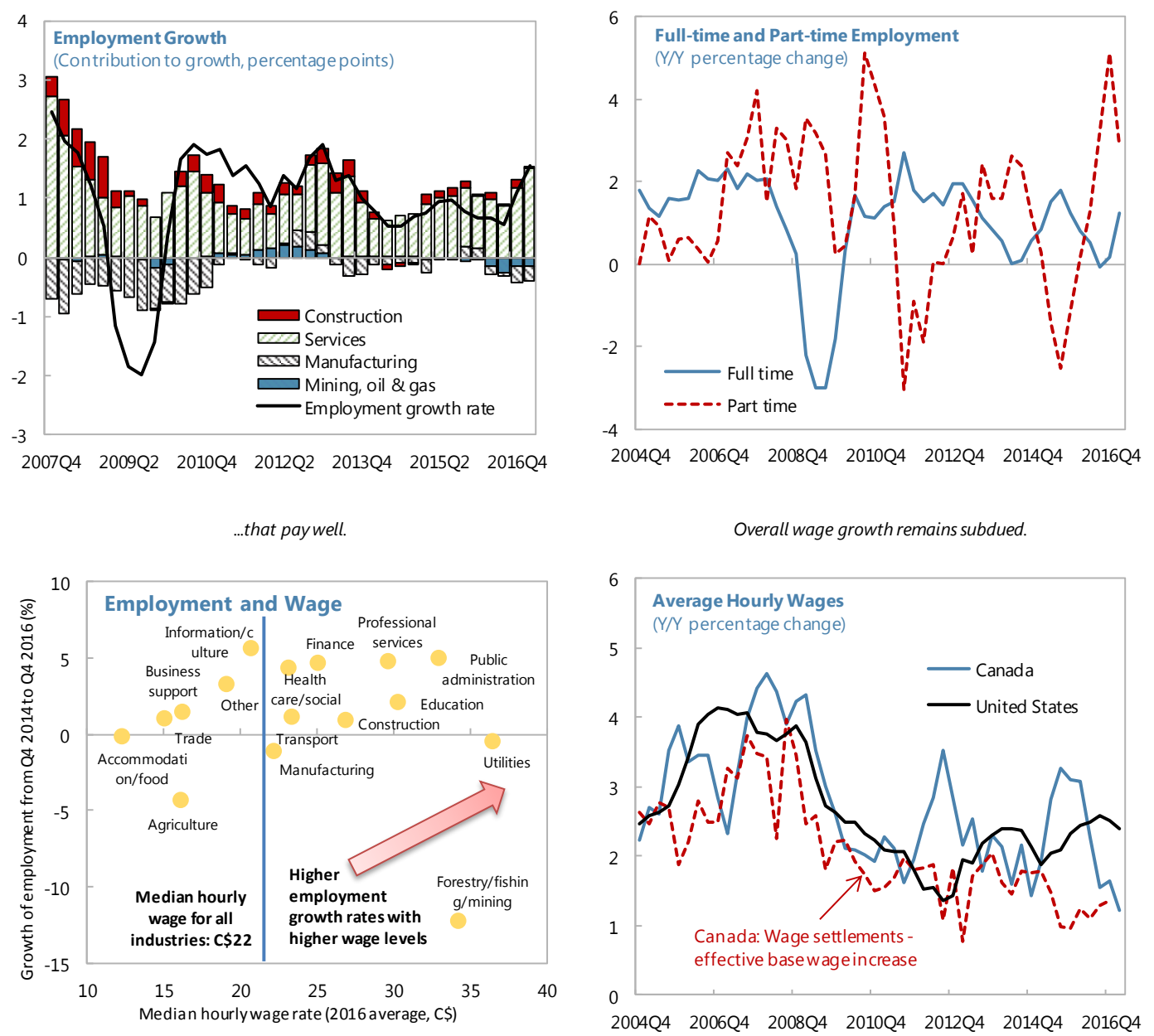

Sources: Statistics Canada; Haver Analytics; and IMF staff calculations.

$1 /$ Seasonally adjusted. 


\section{Figure 3. Canada: Financial Market Performance Remains Strong}

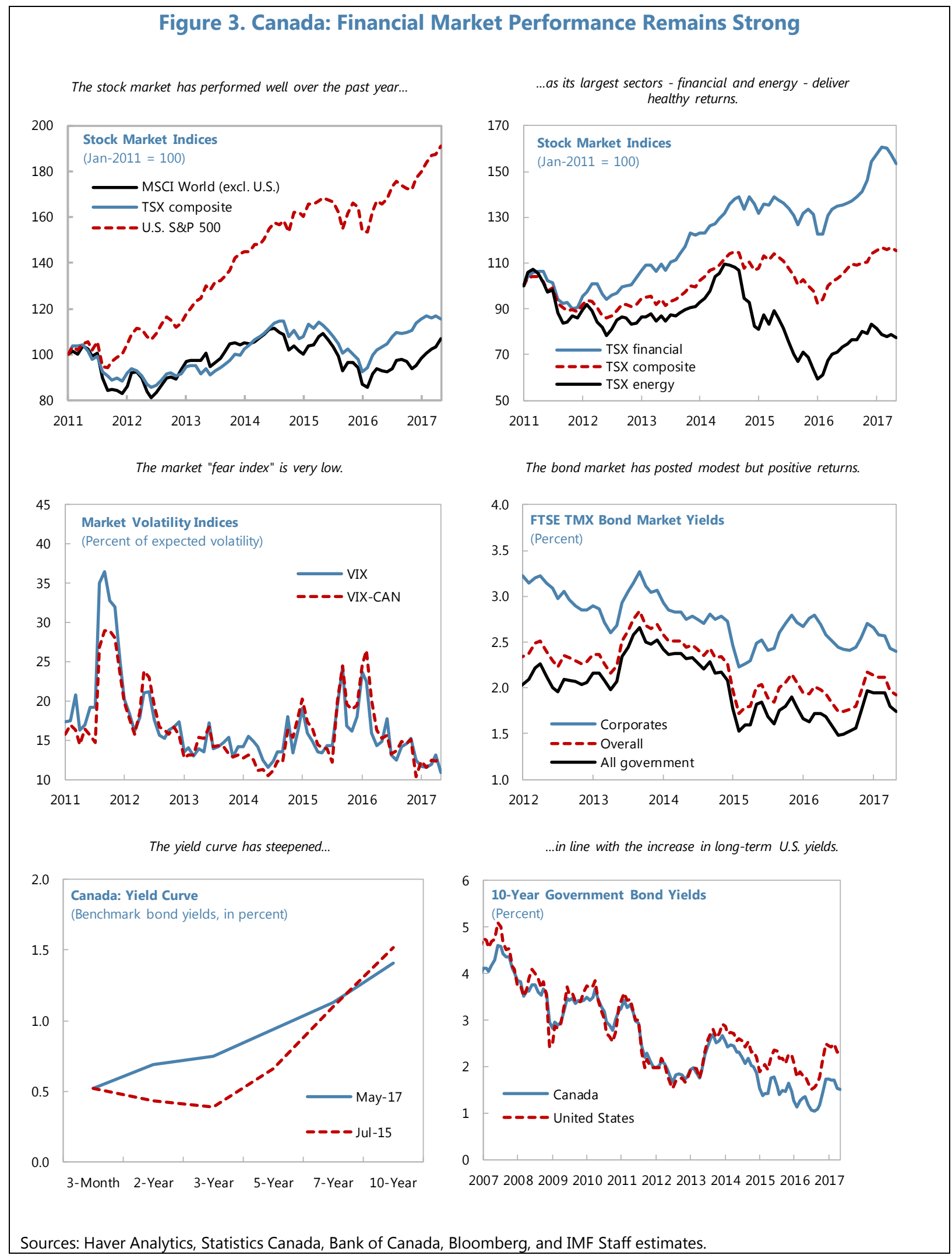




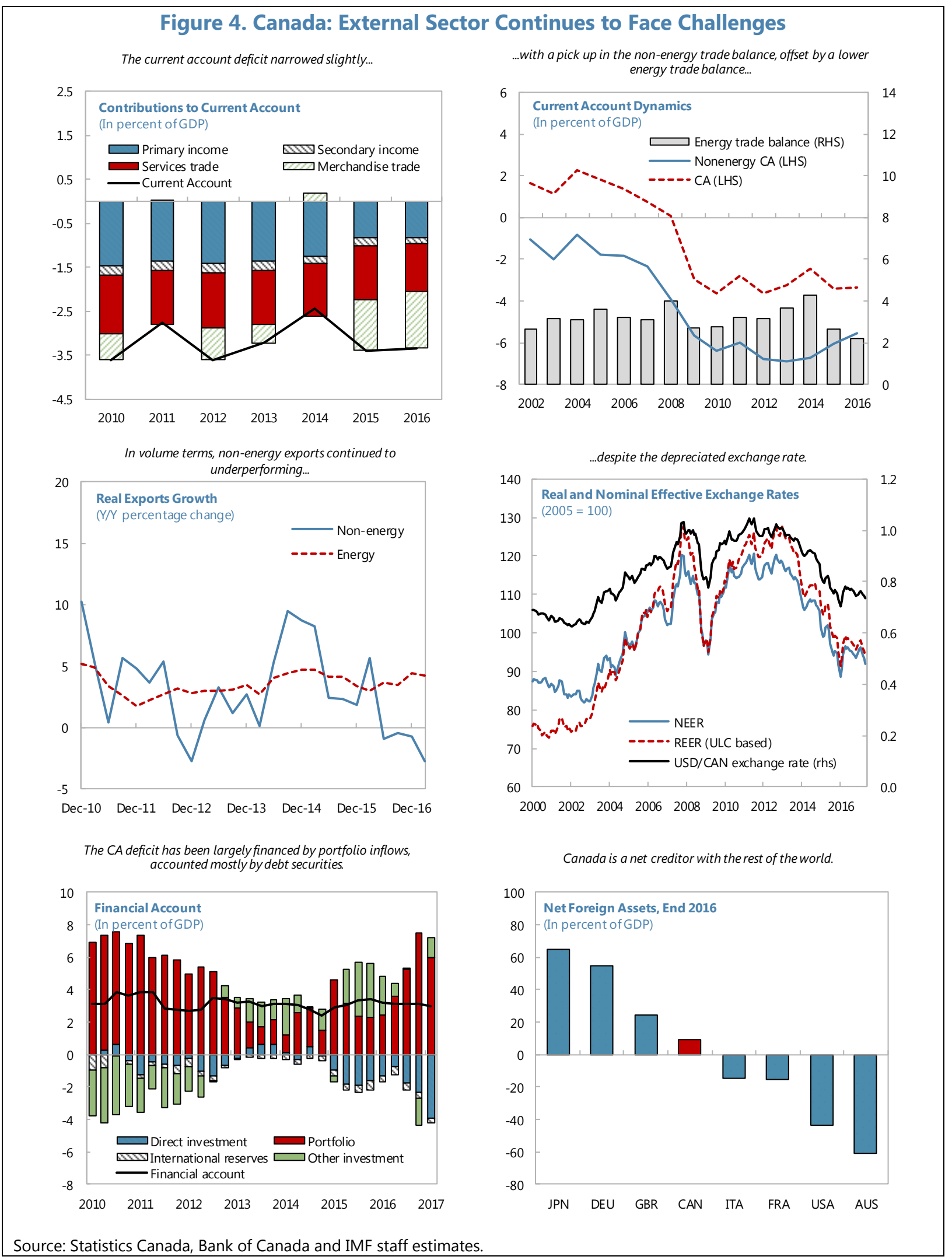


Figure 5a. Canada: Comparing Performance of Canadian Banks (Big-6) and G-SIBS Banks' capital ratios continue to rise along with those of G-SIBs but remain below their level.

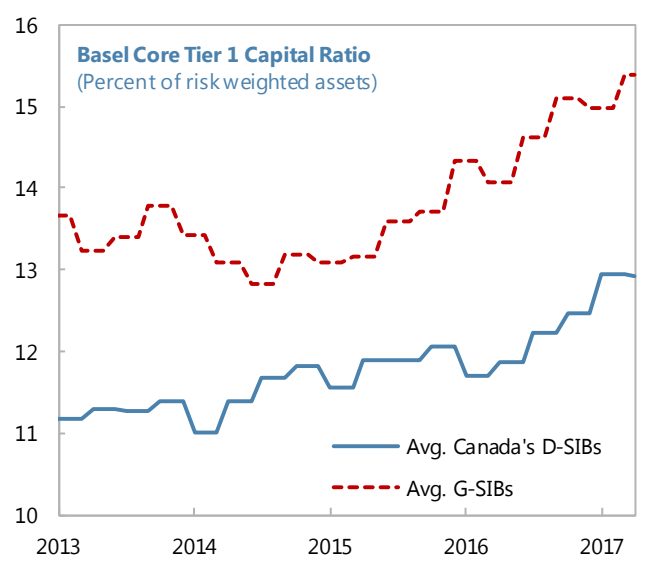

Profitability, while declining, is higher than G-SIBS.

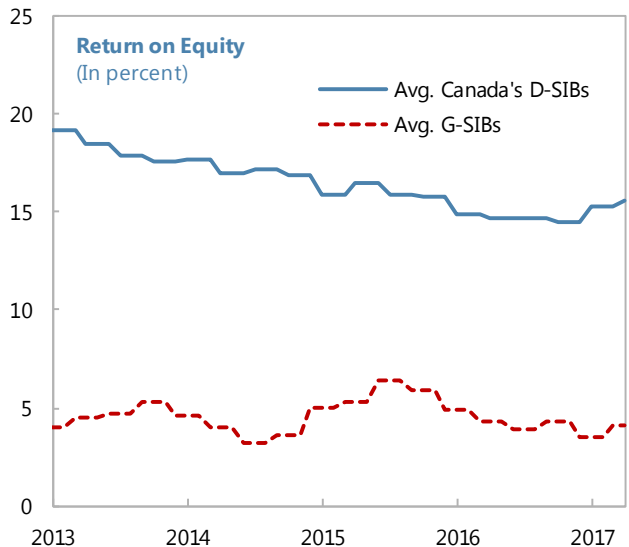

Banks have improved their leverage ratio.

Asset quality is strong and non-performing loans have declined.
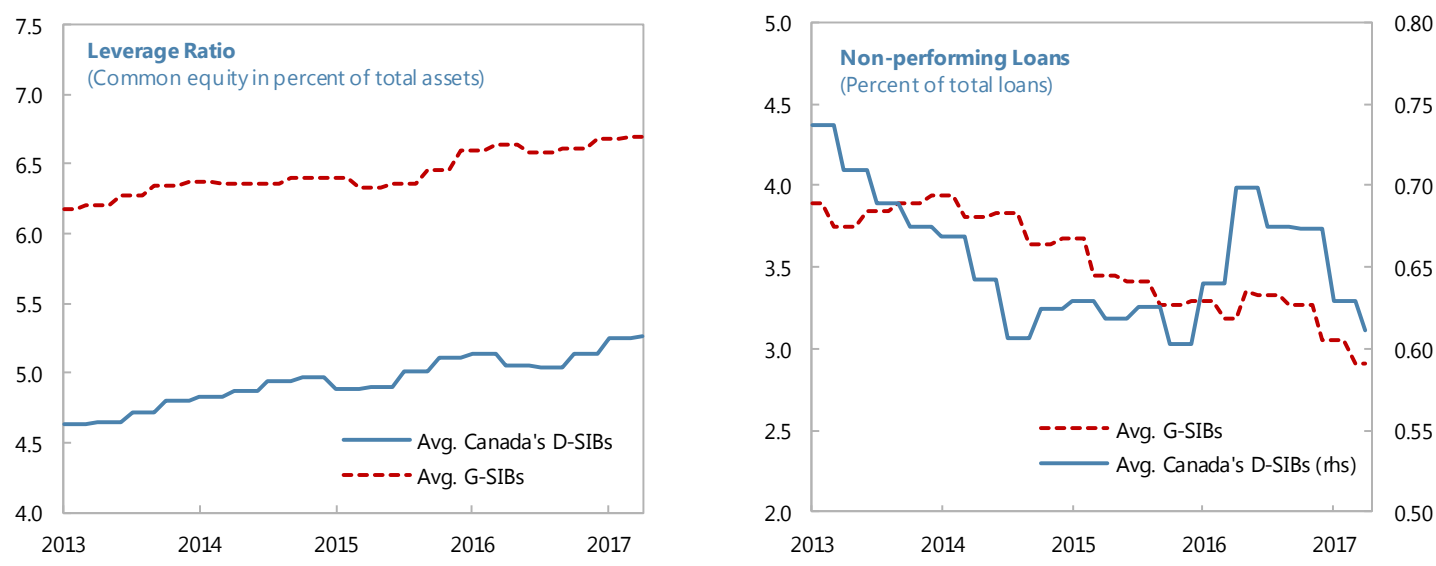

Banks have maintained their net interest margins despite the low interest environment.

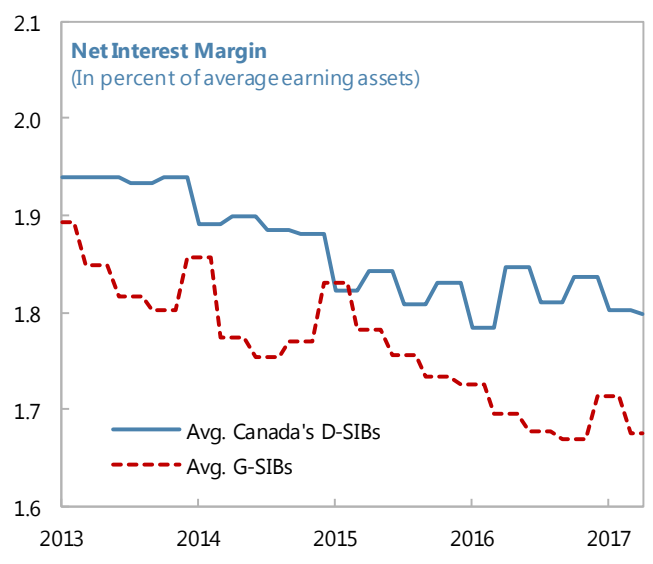

Non-interest expense has been stable.

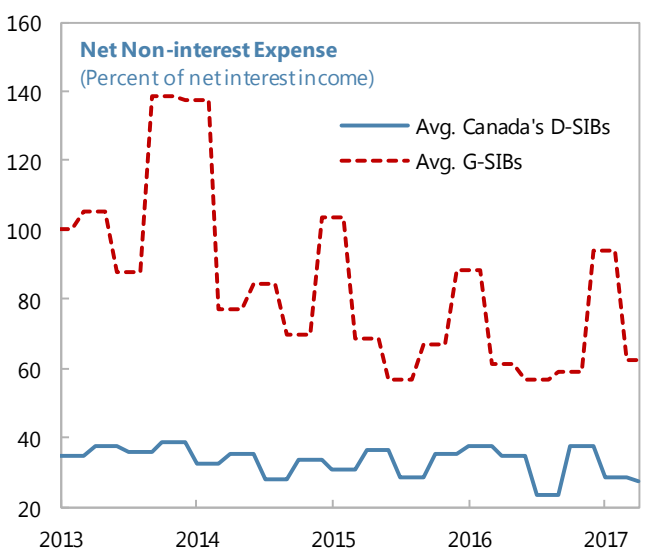

Sources: Bloomberg and IMF staff calculations. 
Figure 5b. Canada: Balance Sheet of Canadian Banking System
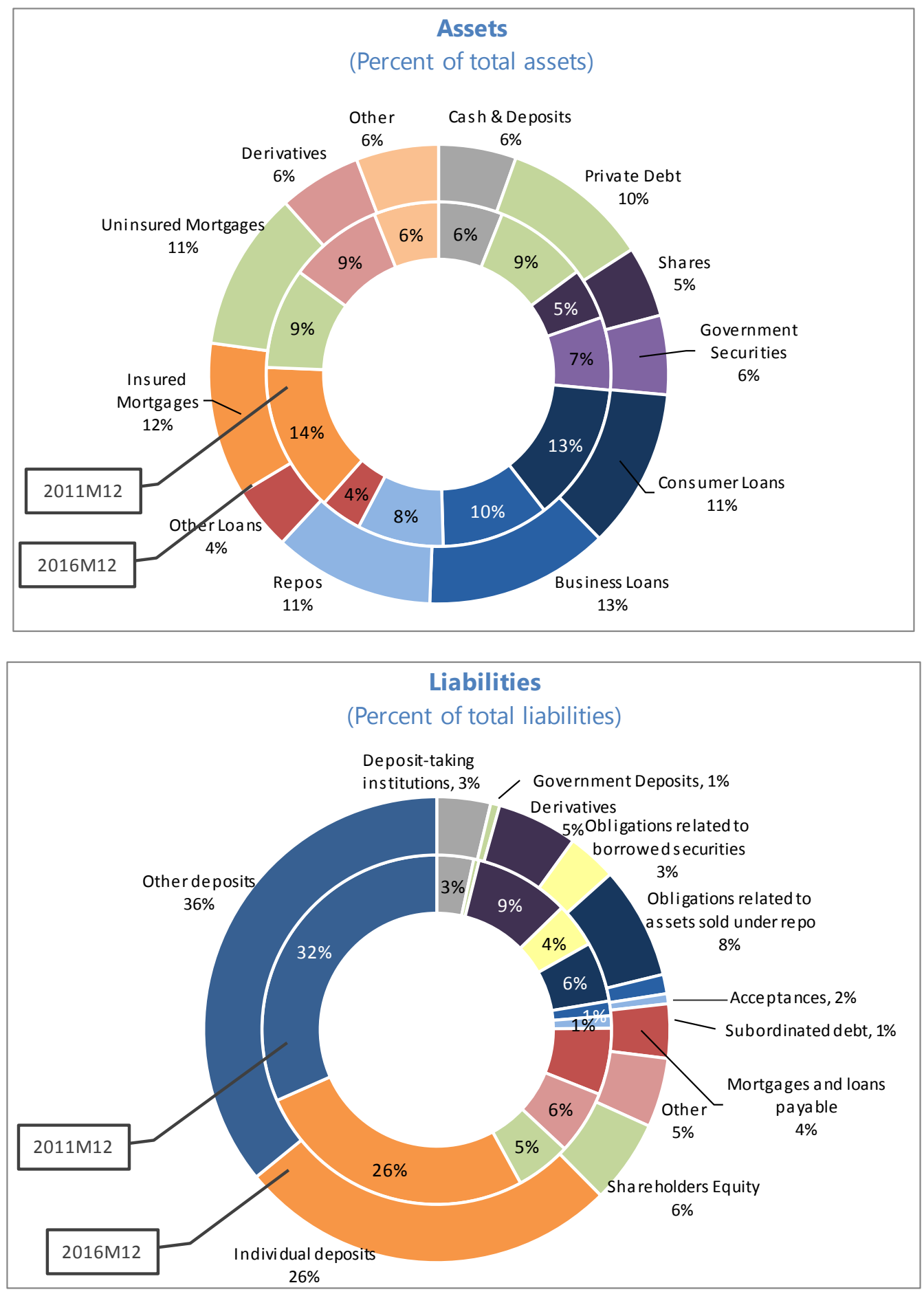

Sources: OSFI and IMF staff estimates. 


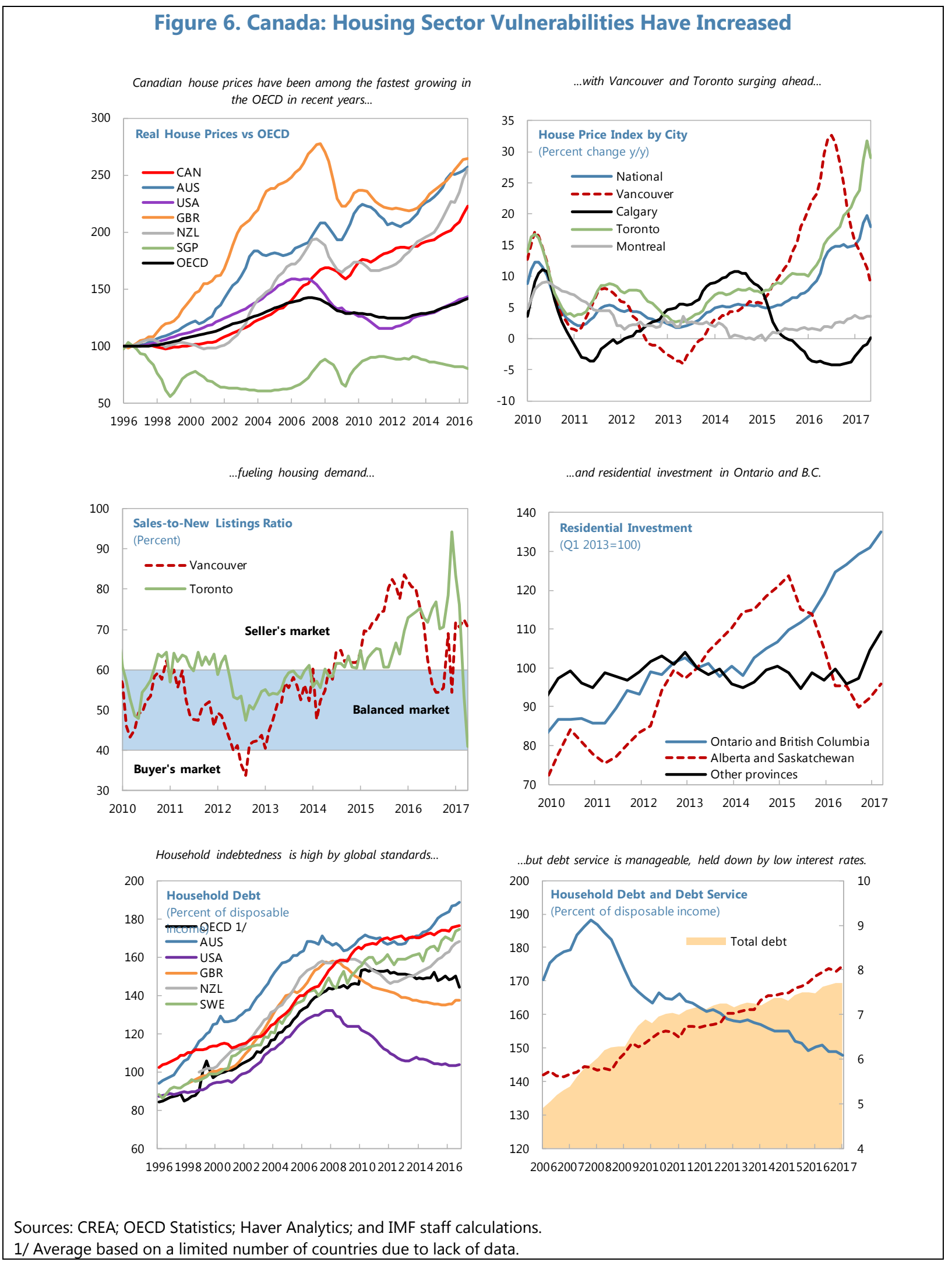

\section{CInternational Monetary Fund. Not for Redistribution}


Figure 7. Canada: Monetary Conditions Remain Favorable

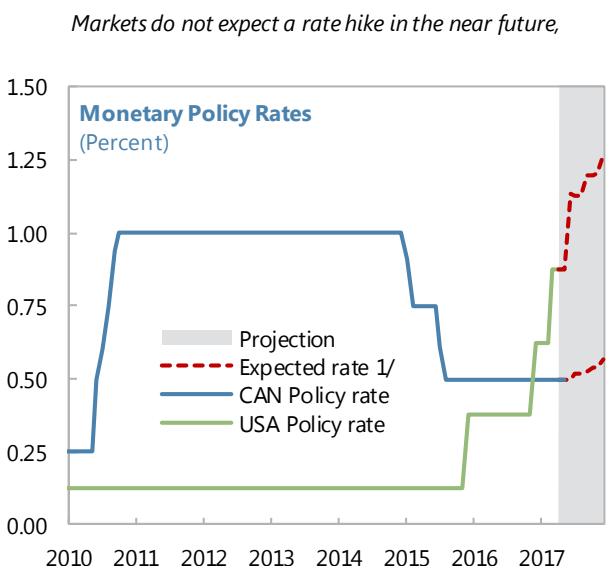

as inflation expectations are well-anchored around the inflation target,
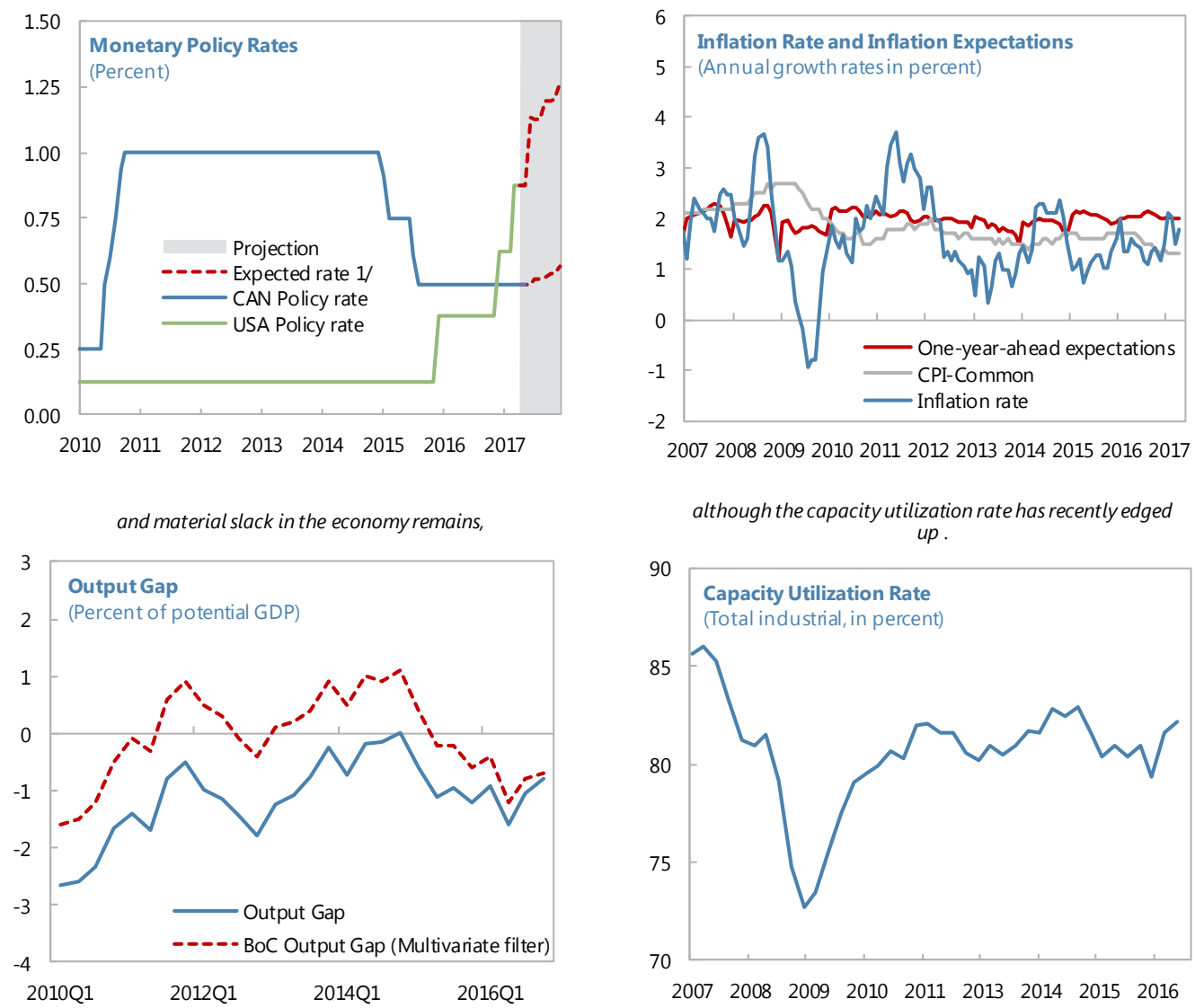

although the capacity utilization rate has recentlyedged up.
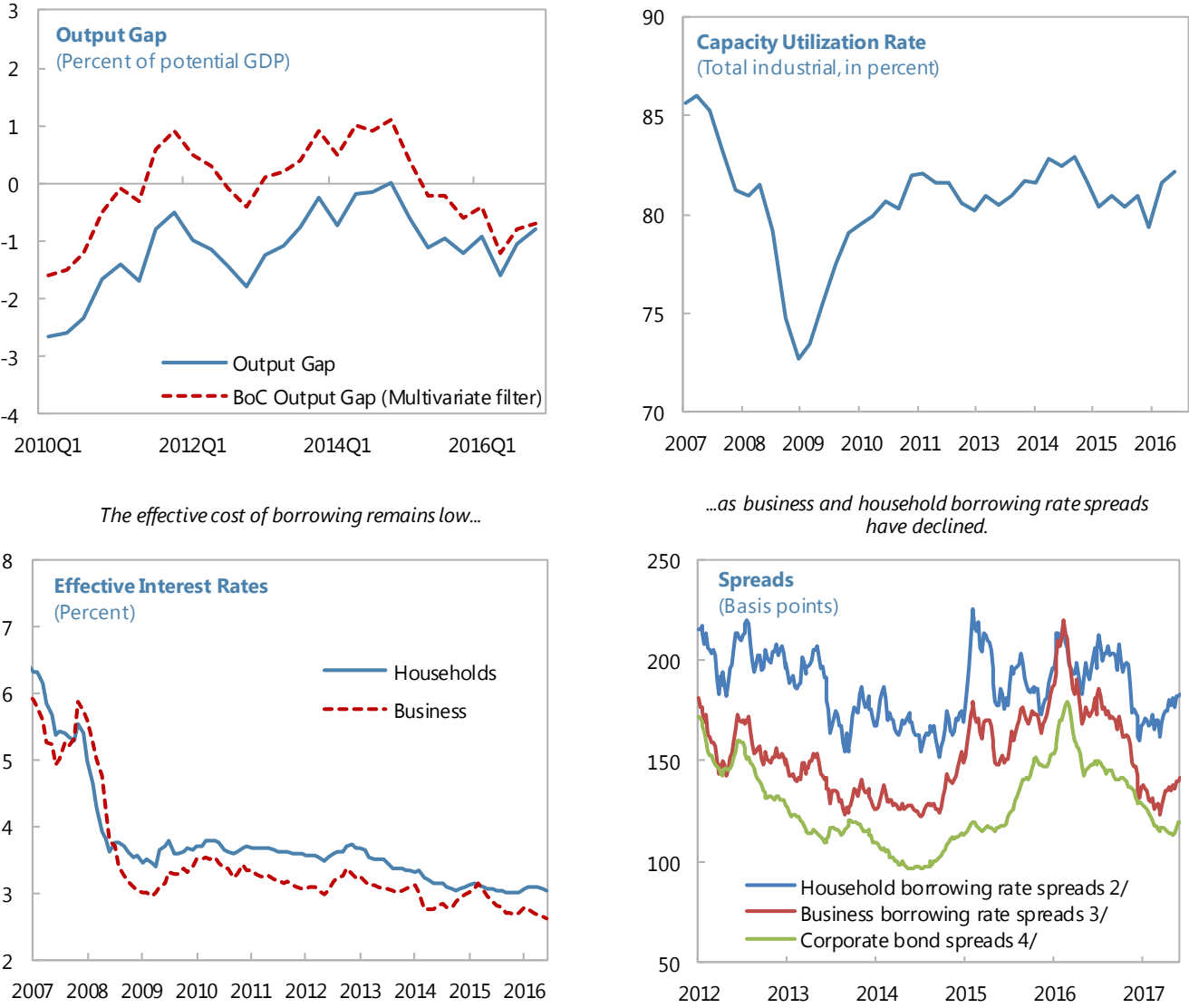

Source: Haver Analytics, Consensus Economics, Statistics Canada, Bank of Canada, Bloomberg, and IMF Staff estimates. 1/ Estimated rate as of April 2017 using Bloomberg's World Interest Rate Implied Probability (WIRP).

2/ Weighted average of various mortgage and consumer loan interest rates minus federal bond average yield.

3/ Estimated effective bank lending rates to business minus federal bond average yield.

4/ FTSE TMX Canada all corporate bond average yield minus federal bond average yield. 


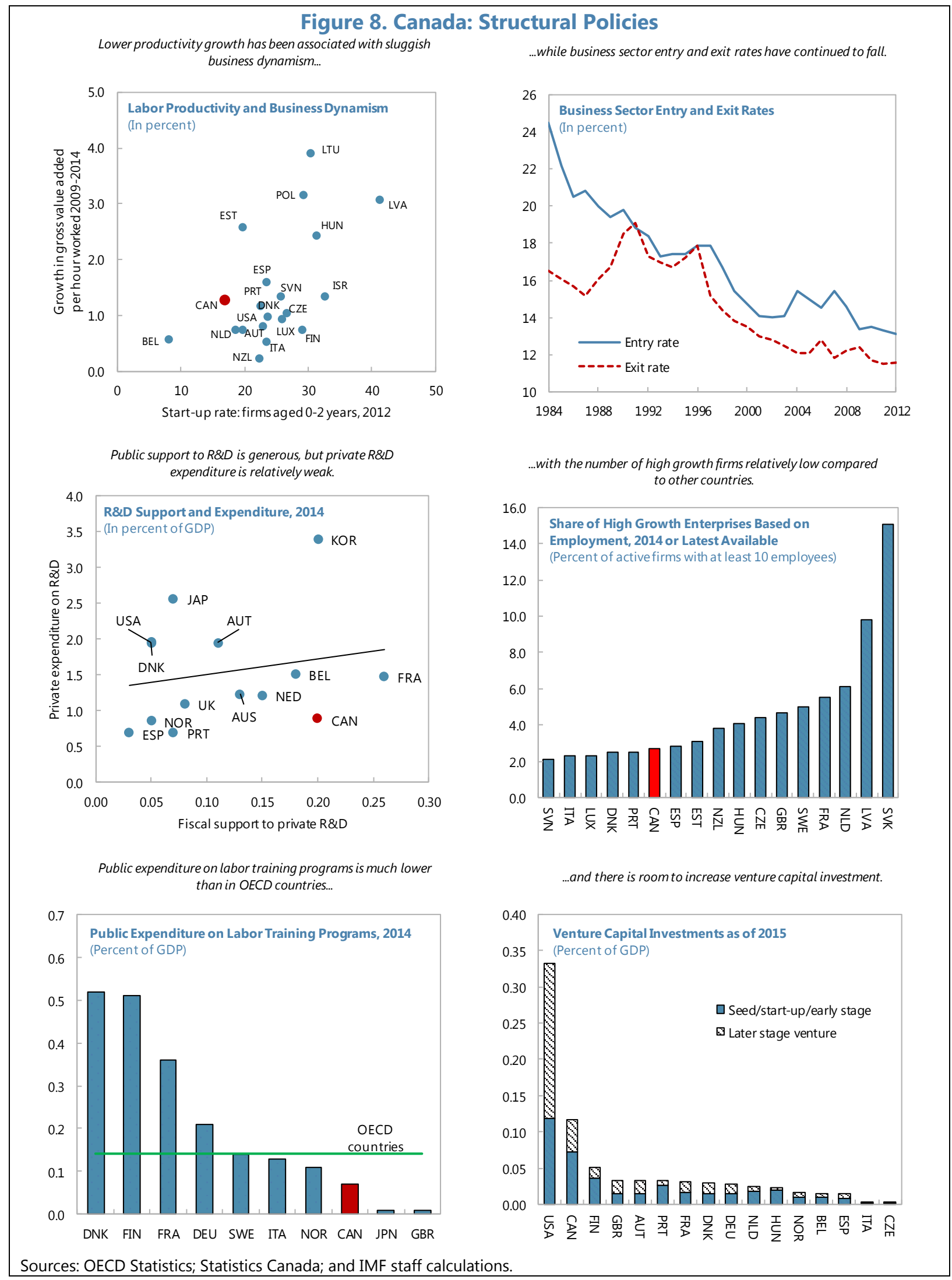


Table 1. Canada: Selected Economic Indicators, 2013-18

(Percentage change, unless otherwise indicated)

Nominal GDP (2016): Can\$2,027 billion (US\$ 1,529 billion)

Quota: SDR 11,023.9 million

GDP per capita (2016): US\$ 42,210

Population (2016): 36.2 million

Main exports: Oil and gas, autos and auto parts, gold, lumber, copper.

\begin{tabular}{|c|c|c|c|c|c|c|}
\hline & \multirow[b]{2}{*}{2013} & \multirow[b]{2}{*}{2014} & \multirow[b]{2}{*}{2015} & \multirow[b]{2}{*}{2016} & \multicolumn{2}{|c|}{ Projections } \\
\hline & & & & & 2017 & 2018 \\
\hline \multicolumn{7}{|l|}{ Output and Demand } \\
\hline Real GDP & 2.5 & 2.6 & 0.9 & 1.5 & 2.5 & 1.9 \\
\hline Total domestic demand & 2.1 & 1.5 & 0.0 & 0.8 & 3.3 & 1.9 \\
\hline Private consumption & 2.6 & 2.7 & 1.9 & 2.3 & 2.4 & 1.9 \\
\hline Total investment & 3.6 & -0.3 & -5.7 & -3.9 & 5.9 & 2.1 \\
\hline Net exports, contribution to growth & 0.3 & 1.1 & 1.0 & 0.6 & -0.2 & 0.0 \\
\hline \multicolumn{7}{|l|}{ Unemployment and Inflation } \\
\hline Unemployment rate (average) 2/ & 7.1 & 6.9 & 6.9 & 7.0 & 6.7 & 6.6 \\
\hline CPI inflation (average) & 0.9 & 1.9 & 1.1 & 1.4 & 1.9 & 2.0 \\
\hline \multicolumn{7}{|l|}{ Saving and Investment $\mathbf{1 /}$} \\
\hline Gross national saving & 21.7 & 22.2 & 20.4 & 19.6 & 19.9 & 20.0 \\
\hline General government & 2.7 & 3.6 & 2.9 & 2.4 & 1.8 & 1.9 \\
\hline Private & 19.0 & 18.6 & 17.5 & 17.2 & 18.1 & 18.1 \\
\hline Personal & 5.6 & 4.8 & 5.7 & 5.9 & 6.1 & 6.1 \\
\hline Business & 13.4 & 13.8 & 11.8 & 11.3 & 12.0 & 12.0 \\
\hline Gross domestic investment & 24.9 & 24.7 & 23.8 & 22.9 & 22.9 & 23.0 \\
\hline \multicolumn{7}{|c|}{ General Government Fiscal Indicators $\mathbf{1 /}$ (NA basis) } \\
\hline Revenue & 38.6 & 38.6 & 39.1 & 38.9 & 38.8 & 38.8 \\
\hline Expenditures & 40.1 & 38.6 & 40.3 & 40.8 & 41.0 & 40.8 \\
\hline Overall balance & -1.5 & 0.0 & -1.1 & -1.9 & -2.2 & -2.0 \\
\hline Gross Debt & 85.8 & 85.4 & 91.6 & 92.3 & 90.3 & 89.0 \\
\hline Net debt & 29.0 & 27.2 & 25.2 & 27.6 & 25.6 & 24.3 \\
\hline \multicolumn{7}{|l|}{ Money and Credit (Annual average) } \\
\hline Household Real Credit Growth & 3.3 & 2.2 & 3.7 & 3.8 & 3.0 & 2.9 \\
\hline Business Real Credit Growth & 6.8 & 5.6 & 7.0 & 3.7 & 3.6 & 4.0 \\
\hline Three-month treasury bill 2/ & 1.0 & 0.9 & 0.5 & 0.5 & 0.5 & 0.8 \\
\hline Ten-year government bond yield 2/ & 2.3 & 2.2 & 1.5 & 1.3 & 1.7 & 2.1 \\
\hline \multicolumn{7}{|l|}{ Balance of Payments } \\
\hline Current account balance 1 / & -3.2 & -2.4 & -3.4 & -3.3 & -3.0 & -3.0 \\
\hline Merchandise Trade balance $1 /$ & -0.4 & 0.2 & -1.2 & -1.3 & -1.1 & -1.2 \\
\hline Export volume (percent change) & 2.9 & 5.7 & 3.7 & 0.5 & 1.5 & 2.8 \\
\hline Import volume (percent change) & 2.0 & 2.3 & 0.3 & -1.2 & 2.4 & 2.8 \\
\hline Terms of trade & 0.0 & -1.3 & -6.9 & -2.0 & 1.8 & -0.4 \\
\hline
\end{tabular}

Sources: Haver Analytics and Fund staff calculations.

1/ Percent of GDP.

2/ In percent. 


\begin{tabular}{|c|c|c|c|c|c|c|c|c|}
\hline \multicolumn{9}{|c|}{$\begin{array}{l}\text { Table 2. Canada: Balance of Payments, 2015-22 } \\
\text { (Percent of GDP) }\end{array}$} \\
\hline & \multirow[b]{2}{*}{2015} & \multirow[b]{2}{*}{2016} & \multicolumn{6}{|c|}{ Projections } \\
\hline & & & 2017 & 2018 & 2019 & 2020 & 2021 & 2022 \\
\hline \multicolumn{9}{|l|}{ Current Account } \\
\hline Current account balance & -3.4 & -3.3 & -3.0 & -3.0 & -2.9 & -2.8 & -2.5 & -2.3 \\
\hline Merchandise trade balance & -1.2 & -1.3 & -1.1 & -1.2 & -1.2 & -1.1 & -0.9 & -0.7 \\
\hline Exports, goods & 26.4 & 25.7 & 26.2 & 26.3 & 26.3 & 26.5 & 26.8 & 27.1 \\
\hline Export volume growth (percentage change) & 3.7 & 0.5 & 1.5 & 2.8 & 3.1 & 3.2 & 3.3 & 3.2 \\
\hline Imports, goods & 27.6 & 27.0 & 27.2 & 27.5 & 27.5 & 27.6 & 27.7 & 27.8 \\
\hline Import volume growth (percentage change) & 0.3 & -1.2 & 2.4 & 2.8 & 3.1 & 2.9 & 3.0 & 3.0 \\
\hline Services balance & -1.2 & -1.1 & -0.9 & -0.8 & -0.8 & -0.8 & -0.8 & -0.8 \\
\hline Primary Income Balance & -0.8 & -0.8 & -0.8 & -0.8 & -0.8 & -0.8 & -0.7 & -0.7 \\
\hline Secondary Income Balance & -0.2 & -0.2 & -0.1 & -0.1 & -0.1 & -0.1 & -0.1 & -0.1 \\
\hline \multicolumn{9}{|l|}{ Capital and Financial Accounts } \\
\hline Direct investment, net & -1.6 & -2.3 & -0.8 & -0.5 & -0.6 & -0.5 & -0.4 & -0.4 \\
\hline Portfolio investment, net & 2.3 & 7.5 & 3.2 & 3.0 & 2.2 & 2.1 & 1.6 & 1.7 \\
\hline Other investment, net 1 / & 3.3 & -1.7 & 0.6 & 0.5 & 1.3 & 1.1 & 1.2 & 1.0 \\
\hline Capital account balance & 0.0 & 0.0 & 0.0 & 0.0 & 0.0 & 0.0 & 0.0 & 0.0 \\
\hline International reserves & -0.5 & -0.4 & 0.0 & 0.0 & 0.0 & 0.0 & 0.0 & 0.0 \\
\hline Statistical discrepancy & 0.0 & 0.2 & 0.0 & 0.0 & 0.0 & 0.0 & 0.0 & 0.0 \\
\hline \multicolumn{9}{|l|}{ Memorandum Items } \\
\hline Terms of trade (percent change) & -6.9 & -2.0 & 1.8 & -0.4 & 0.1 & 0.3 & 0.4 & 0.4 \\
\hline Net international investment position $2 /$ & 21.7 & 9.3 & $\ldots$ & $\ldots$ & $\ldots$ & $\ldots$ & $\ldots$ & $\ldots$ \\
\hline Assets & 203.6 & 212.7 & $\ldots$ & $\ldots$ & $\ldots$ & $\ldots$ & $\ldots$ & $\ldots$ \\
\hline FDI & 78.9 & 84.5 & $\ldots$ & $\ldots$ & $\ldots$ & $\ldots$ & $\ldots$ & $\ldots$ \\
\hline Portfolio 2/ & 84.7 & 86.3 & $\ldots$ & $\ldots$ & $\ldots$ & $\ldots$ & $\ldots$ & $\ldots$ \\
\hline Other & 34.4 & 36.3 & $\ldots$ & $\ldots$ & $\ldots$ & $\ldots$ & $\ldots$ & $\ldots$ \\
\hline Reserves & 5.6 & 5.5 & $\ldots$ & $\ldots$ & $\ldots$ & $\ldots$ & $\ldots$ & $\ldots$ \\
\hline Liabilities & 181.9 & 203.4 & $\ldots$ & $\ldots$ & $\ldots$ & $\ldots$ & $\ldots$ & $\ldots$ \\
\hline FDI & 57.1 & 67.1 & $\ldots$ & $\ldots$ & $\ldots$ & $\ldots$ & $\ldots$ & $\ldots$ \\
\hline Portfolio 2/ & 85.9 & 96.6 & $\ldots$ & $\ldots$ & $\ldots$ & $\ldots$ & $\ldots$ & $\ldots$ \\
\hline Other & 39.0 & 39.8 & $\ldots$ & $\ldots$ & $\ldots$ & $\ldots$ & $\ldots$ & $\ldots$ \\
\hline Gross external debt & 110.9 & 115.4 & 118.5 & 121.0 & 123.0 & 124.7 & 125.9 & 126.5 \\
\hline Real effective exchange rate $3 /$ & -8.8 & -2.4 & $\cdots$ & $\cdots$ & $\cdots$ & $\cdots$ & $\cdots$ & $\cdots$ \\
\hline \multicolumn{9}{|c|}{$\begin{array}{l}\text { Sources: Haver Analytics and Fund staff calculations. } \\
\text { 1/ Includes bank, nonbank, and official transactions other than reserve transactions. } \\
\text { 2/ Based on market valuation of portfolio stocks and official international reserves. } \\
\text { 3/ Percentage change. }\end{array}$} \\
\hline
\end{tabular}


Table 3. Canada: External Debt 2007-16 1/

(End period)

\begin{tabular}{|c|c|c|c|c|c|c|c|c|c|c|}
\hline & 2007 & 2008 & 2009 & 2010 & 2011 & 2012 & 2013 & 2014 & 2015 & 2016 \\
\hline \multicolumn{11}{|c|}{ (In percent of GDP) } \\
\hline Total All Sectors & 57.4 & 67.8 & 73.4 & 73.8 & 76.0 & 82.6 & 85.0 & 92.1 & 110.9 & 115.4 \\
\hline Short-term & 20.2 & 23.6 & 22.9 & 21.7 & 22.6 & 24.7 & 25.3 & 29.9 & 39.3 & 40.7 \\
\hline Long-term & 29.3 & 33.2 & 38.7 & 41.4 & 44.6 & 48.6 & 49.3 & 52.4 & 61.6 & 65.2 \\
\hline General Government & 9.8 & 11.4 & 14.6 & 17.5 & 20.3 & 22.4 & 20.6 & 20.2 & 22.0 & 21.9 \\
\hline Short-term & 0.7 & 1.4 & 1.6 & 1.6 & 3.1 & 3.2 & 2.7 & 2.3 & 2.2 & 1.9 \\
\hline Long-term & 9.1 & 10.0 & 13.0 & 15.8 & 17.2 & 19.2 & 17.8 & 17.9 & 19.8 & 19.9 \\
\hline Monetary Authorities & 0.0 & 0.0 & 0.0 & 0.0 & 0.0 & 0.0 & 0.0 & 0.0 & 0.0 & 0.0 \\
\hline Banks & 16.8 & 20.2 & 20.1 & 19.5 & 20.3 & 22.3 & 24.4 & 30.0 & 40.6 & 45.3 \\
\hline Short-term & 16.5 & 19.5 & 19.2 & 17.4 & 16.7 & 18.0 & 19.2 & 24.1 & 32.5 & 33.5 \\
\hline Long-term & 0.3 & 0.7 & 0.9 & 2.1 & 3.6 & 4.3 & 5.3 & 5.9 & 8.1 & 11.8 \\
\hline Other Sectors & 22.8 & 25.2 & 26.9 & 26.2 & 26.6 & 28.6 & 29.6 & 32.2 & 38.3 & 38.8 \\
\hline Short-term & 2.9 & 2.7 & 2.1 & 2.7 & 2.8 & 3.5 & 3.4 & 3.5 & 4.6 & 5.2 \\
\hline Long-term & 19.9 & 22.5 & 24.8 & 23.4 & 23.8 & 25.1 & 26.2 & 28.7 & 33.7 & 33.5 \\
\hline \multicolumn{11}{|c|}{ (In billions of US dollar) } \\
\hline Total All Sectors & 920 & 925 & 1,089 & 1,211 & 1,315 & 1,519 & 1,536 & 1,608 & 1,649 & 1,754 \\
\hline Short-term & 323 & 321 & 340 & 356 & 391 & 454 & 457 & 522 & 585 & 618 \\
\hline Long-term & 469 & 453 & 573 & 679 & 771 & 894 & 891 & 915 & 916 & 991 \\
\hline General Government & 158 & 156 & 216 & 286 & 351 & 411 & 372 & 352 & 327 & 332 \\
\hline Short-term & 12 & 19 & 23 & 26 & 54 & 59 & 50 & 40 & 32 & 29 \\
\hline Long-term & 146 & 137 & 193 & 260 & 297 & 353 & 322 & 312 & 294 & 303 \\
\hline Monetary Authorities & 0 & 0 & 0 & 0 & 0 & 0 & 0 & 0 & 0 & 0 \\
\hline Banks & 269 & 275 & 298 & 320 & 351 & 410 & 441 & 523 & 604 & 688 \\
\hline Short-term & 265 & 265 & 285 & 285 & 289 & 331 & 346 & 420 & 484 & 509 \\
\hline Long-term & 4 & 9 & 13 & 35 & 62 & 79 & 95 & 103 & 120 & 179 \\
\hline Other Sectors & 366 & 343 & 399 & 429 & 460 & 526 & 535 & 562 & 569 & 589 \\
\hline Short-term & 47 & 37 & 31 & 44 & 48 & 64 & 61 & 61 & 68 & 79 \\
\hline Long-term & 319 & 306 & 367 & 385 & 412 & 462 & 474 & 500 & 501 & 510 \\
\hline
\end{tabular}

Source: Haver Analytics and IMF Staff estimates.

1/ Short-term instruments include: money market, loans, deposits, trade credits, and other debt liabilities.

Long term includes: bonds and notes, loans, and other debt liabilities. 
Table 4. Canada: General Government Fiscal Indicators, 2014-22 1/

(Percent of GDP, unless otherwise indicated)

\begin{tabular}{|c|c|c|c|c|c|c|c|c|c|}
\hline & \multirow[b]{2}{*}{2014} & \multirow[b]{2}{*}{2015} & \multirow[b]{2}{*}{2016} & \multicolumn{6}{|c|}{ Projections } \\
\hline & & & & 2017 & 2018 & 2019 & 2020 & 2021 & 2022 \\
\hline \multicolumn{10}{|l|}{ Federal Government } \\
\hline Revenue & 13.8 & 14.0 & 13.7 & 13.6 & 13.6 & 13.6 & 13.6 & 13.6 & 13.6 \\
\hline Income taxes & 8.9 & 9.0 & 8.8 & 8.8 & 8.8 & 8.8 & 8.8 & 8.8 & 8.9 \\
\hline Expenditures & 13.4 & 14.1 & 14.5 & 14.9 & 14.8 & 14.7 & 14.5 & 14.4 & 14.4 \\
\hline Program spending & 13.0 & 13.9 & 14.5 & 14.5 & 14.3 & 14.0 & 13.9 & 13.8 & 13.6 \\
\hline Transfers & 8.4 & 9.0 & 9.3 & 9.3 & 9.2 & 9.2 & 9.1 & 9.1 & 9.1 \\
\hline Interest payments & 1.2 & 1.2 & 1.1 & 1.1 & 1.1 & 1.1 & 1.1 & 1.2 & 1.3 \\
\hline Budgetary balance & 0.4 & 0.0 & -0.8 & -1.3 & -1.3 & -1.1 & -0.9 & -0.8 & -0.8 \\
\hline Cyclically-adjusted balance 2/ & 0.5 & 0.1 & -0.7 & -1.3 & -1.3 & -1.1 & -1.0 & -0.9 & -0.8 \\
\hline Net federal debt & 22.6 & 22.7 & 22.9 & 22.7 & 22.5 & 22.0 & 21.7 & 21.0 & 20.6 \\
\hline Gross federal debt & 37.3 & 39.6 & 39.2 & 38.7 & 38.5 & 38.1 & 37.7 & 37.1 & 36.6 \\
\hline \multicolumn{10}{|l|}{ Provincial and Local Governments } \\
\hline Revenue & 25.7 & 25.8 & 26.1 & 26.1 & 26.0 & 26.0 & 26.0 & 26.0 & 26.0 \\
\hline Income taxes & 5.9 & 6.1 & 6.2 & 6.2 & 6.3 & 6.3 & 6.3 & 6.3 & 6.3 \\
\hline Expenditures & 26.6 & 27.5 & 27.6 & 27.5 & 27.3 & 27.2 & 27.1 & 27.0 & 26.9 \\
\hline Interest payments & 1.9 & 1.9 & 1.9 & 1.8 & 1.7 & 1.7 & 1.7 & 1.7 & 1.7 \\
\hline Budgetary balance & -0.9 & -1.6 & -1.5 & -1.4 & -1.3 & -1.2 & -1.1 & -1.0 & -0.9 \\
\hline \multicolumn{10}{|l|}{ Canada/Quebec Pension Plans } \\
\hline Revenue & 3.2 & 3.4 & 3.4 & 3.4 & 3.5 & 3.4 & 3.4 & 3.4 & 3.4 \\
\hline Total spending & 2.7 & 2.9 & 2.9 & 2.9 & 2.9 & 2.9 & 2.9 & 2.9 & 2.9 \\
\hline Budgetary balance & 0.4 & 0.5 & 0.5 & 0.5 & 0.6 & 0.5 & 0.5 & 0.5 & 0.5 \\
\hline \multicolumn{10}{|l|}{ Consolidated General Government 3/ } \\
\hline Revenue & 38.6 & 39.1 & 38.9 & 38.8 & 38.8 & 38.8 & 38.8 & 38.8 & 38.9 \\
\hline Expenditure & 38.6 & 40.3 & 40.8 & 41.0 & 40.8 & 40.5 & 40.3 & 40.2 & 40.0 \\
\hline Overall balance & 0.0 & -1.1 & -1.9 & -2.2 & -2.0 & -1.7 & -1.5 & -1.4 & -1.2 \\
\hline Primary balance & 0.2 & -0.5 & -1.1 & -1.5 & -1.5 & -1.2 & -0.9 & -0.6 & -0.4 \\
\hline Cyclically-adjusted balance 2/ & 0.1 & -0.7 & -1.4 & -2.2 & -2.1 & -1.9 & -1.7 & -1.5 & -1.3 \\
\hline Net public debt & 27.2 & 25.2 & 27.6 & 25.6 & 24.3 & 22.7 & 20.9 & 19.0 & 16.9 \\
\hline Gross public debt & 85.4 & 91.6 & 92.3 & 90.3 & 89.0 & 87.3 & 85.6 & 83.7 & 81.6 \\
\hline \multicolumn{10}{|l|}{ Memorandum Items } \\
\hline Real GDP growth (percentage change) & 2.6 & 0.9 & 1.5 & 2.5 & 1.9 & 1.8 & 1.8 & 1.8 & 1.8 \\
\hline Nominal GDP growth (percentage change) & 4.5 & 0.2 & 2.1 & 4.8 & 3.9 & 4.0 & 3.9 & 3.9 & 3.9 \\
\hline \multicolumn{10}{|c|}{$\begin{array}{l}\text { Sources: Statistics Canada; Department of Finance Canada; provincial budget reports; Haver Analytics; and IMF staff } \\
\text { estimates. }\end{array}$} \\
\hline \multicolumn{10}{|l|}{ 1/ National Accounts basis. } \\
\hline \multicolumn{10}{|l|}{ 2/ Percent of potential GDP. } \\
\hline 3/ Includes federal, provincial, & & & & & & & & & \\
\hline
\end{tabular}


Table 5. Canada: Statement of General Government Operations and Balance Sheet, 2010-2016 1/ (Percent of GDP, unless otherwise indicated)

\begin{tabular}{|c|c|c|c|c|c|c|c|}
\hline & 2010 & 2011 & 2012 & 2013 & 2014 & 2015 & 2016 \\
\hline \multicolumn{8}{|l|}{ Government operations } \\
\hline Revenue & 38.5 & 38.4 & 38.6 & 38.6 & 38.6 & 39.2 & 39.0 \\
\hline Taxes & 26.6 & 26.5 & 26.7 & 26.6 & 26.7 & 27.4 & 27.5 \\
\hline Social contributions & 4.6 & 4.5 & 4.7 & 4.7 & 4.6 & 4.8 & 4.8 \\
\hline Grants & 0.1 & 0.1 & 0.1 & 0.1 & 0.1 & 0.1 & 0.1 \\
\hline Other revenue & 7.3 & 7.4 & 7.1 & 7.2 & 7.2 & 6.9 & 6.7 \\
\hline Total expenditure & 43.2 & 41.7 & 41.0 & 40.1 & 38.6 & 40.3 & 40.8 \\
\hline Expense & 41.4 & 40.5 & 40.0 & 39.4 & 38.5 & 39.8 & 40.2 \\
\hline Compensation of employees & 12.4 & 12.2 & 12.2 & 12.1 & 11.9 & 12.2 & 12.4 \\
\hline Use of goods and services & 9.0 & 8.8 & 8.7 & 8.4 & 8.3 & 8.5 & 8.6 \\
\hline Consumption of fixed capital & 3.1 & 3.2 & 3.2 & 3.2 & 3.2 & 3.3 & 3.3 \\
\hline Interest & 3.7 & 3.6 & 3.5 & 3.4 & 3.2 & 3.1 & 3.0 \\
\hline Subsidies & 1.1 & 1.1 & 1.1 & 0.9 & 0.9 & 0.9 & 0.9 \\
\hline Grants & 0.3 & 0.3 & 0.3 & 0.3 & 0.2 & 0.2 & 0.3 \\
\hline Net acquisition of nonfinancial assets & 1.8 & 1.2 & 1.0 & 0.7 & 0.1 & 0.4 & 0.6 \\
\hline Gross operating balance & 0.2 & 1.1 & 1.8 & 2.4 & 3.4 & 2.7 & 2.1 \\
\hline Net operating balance & -2.9 & -2.1 & -1.5 & -0.8 & 0.1 & -0.7 & -1.2 \\
\hline Net lending or borrowing & -4.7 & -3.3 & -2.5 & -1.4 & 0.0 & -1.1 & -1.8 \\
\hline \multicolumn{8}{|l|}{ Balance sheet } \\
\hline Net worth & -1.3 & -2.3 & -8.2 & 0.9 & -0.8 & -6.1 & -3.4 \\
\hline Nonfinancial assets & 48.6 & 50.7 & 45.4 & 49.3 & 46.6 & 41.3 & 44.0 \\
\hline Net financial worth & -50.0 & -53.0 & -53.6 & -48.4 & -47.4 & -47.4 & -47.4 \\
\hline Financial assets & 55.2 & 54.9 & 57.9 & 59.1 & 61.5 & 68.5 & 68.1 \\
\hline Currency and deposits & 3.2 & 3.1 & 3.9 & 4.5 & 4.7 & 5.4 & 5.5 \\
\hline Securities other than shares & 7.1 & 6.7 & 6.4 & 6.6 & 6.9 & 8.7 & 7.9 \\
\hline Loans & 12.6 & 12.3 & 12.3 & 11.5 & 10.7 & 11.7 & 11.9 \\
\hline Shares and other equity & 20.3 & 20.8 & 22.4 & 24.0 & 26.0 & 30.1 & 31.3 \\
\hline Insurance technical reserves & 0.0 & 0.0 & 0.0 & 0.0 & 0.0 & 0.0 & 0.0 \\
\hline Other accounts receivable & 12.0 & 11.9 & 13.0 & 12.4 & 13.2 & 12.5 & 11.5 \\
\hline Financial liabilities & 105.2 & 107.9 & 111.5 & 107.5 & 108.8 & 115.9 & 115.6 \\
\hline Currency and deposits & 0.3 & 0.3 & 0.3 & 0.3 & 0.3 & 0.3 & 0.3 \\
\hline Securities other than shares & 67.9 & 71.4 & 74.0 & 69.6 & 70.7 & 74.5 & 75.6 \\
\hline Loans & 3.1 & 3.1 & 2.9 & 3.2 & 3.2 & 3.4 & 3.3 \\
\hline Shares and other equity & 0.0 & 0.0 & 0.0 & 0.0 & 0.0 & 0.0 & 0.0 \\
\hline Insurance technical reserves & 19.4 & 19.3 & 19.2 & 18.0 & 17.1 & 18.0 & 17.0 \\
\hline Other accounts payable & 14.5 & 13.8 & 15.2 & 16.5 & 17.6 & 19.8 & 19.4 \\
\hline \multicolumn{8}{|l|}{ Memorandum items: } \\
\hline Nominal GDP (in billions of Can\$) & 1,662 & 1,770 & 1,823 & 1,898 & 1,983 & 1,986 & 2,028 \\
\hline
\end{tabular}

Sources: Statistics Canada; and Haver Analytics.

1/ Government Finance Statistics basis. 
Table 6. Canada: Financial Sound ness Indicators 2011-16

(Percent, unless otherwise indicated)

\begin{tabular}{|c|c|c|c|c|c|c|}
\hline & 2011 & 2012 & 2013 & 2014 & 2015 & 2016 \\
\hline \multicolumn{7}{|l|}{ Total Assets } \\
\hline Total assets $1 /$ & 3,265 & 3,682 & 3,854 & 4,179 & 4,666 & 4,984 \\
\hline Percent of GDP & 180.5 & 200.2 & 199.9 & 209.0 & 234.2 & 240.6 \\
\hline Nominal GDP & 1,809 & 1,840 & 1,928 & 2,000 & 1,992 & 2,071 \\
\hline \multicolumn{7}{|l|}{ Capital Adequacy } \\
\hline Total capital ratio & 15.9 & 16.2 & 14.3 & 14.2 & 14.2 & 14.8 \\
\hline Tier 1 ratio & 13.3 & 13.4 & 11.7 & 11.9 & 12.1 & 12.5 \\
\hline Capital to assets & 4.9 & 4.9 & 5.0 & 4.9 & 5.1 & 5.2 \\
\hline \multicolumn{7}{|l|}{ Credit Risk } \\
\hline NPLs net of provisions to capital & 6.6 & 6.4 & 6.2 & 5.5 & 5.3 & 6.0 \\
\hline NPLs to Gross Loans & 0.8 & 0.7 & 0.6 & 0.5 & 0.5 & 0.6 \\
\hline Provisions (Individual) to NPL & 30.1 & 22.3 & 16.3 & 17.5 & 17.3 & 16.7 \\
\hline \multicolumn{7}{|l|}{ Sectoral Distribution of Loans } \\
\hline Residents & 76.7 & 74.3 & 73.6 & 71.4 & 67.5 & 68.2 \\
\hline Nonresidents & 23.3 & 25.7 & 26.4 & 28.6 & 32.5 & 31.8 \\
\hline \multicolumn{7}{|l|}{ Profitability } \\
\hline Return on assets & 1.1 & 1.1 & 1.1 & 1.1 & 1.0 & 1.0 \\
\hline Return on equity & 23.6 & 22.7 & 22.3 & 22.5 & 20.7 & 19.9 \\
\hline Interest margin on gross income & 49.4 & 52.0 & 52.5 & 51.3 & 51.1 & 50.7 \\
\hline Trading income to gross income & 4.2 & 5.3 & 4.5 & 3.7 & 3.8 & 4.8 \\
\hline Non-interest expenses to gross income & 63.8 & 63.3 & 62.6 & 62.8 & 63.7 & 63.6 \\
\hline \multicolumn{7}{|l|}{ Liquidity } \\
\hline Liquid assets to total assets & 15.2 & 11.9 & 11.3 & 11.0 & 11.5 & 10.9 \\
\hline Liquid assets to short-term liabilities & 54.1 & 51.8 & 47.8 & 50.5 & 45.4 & 54.1 \\
\hline Customer deposits to loans & 114.2 & 96.3 & 98.2 & 99.3 & 101.0 & 101.6 \\
\hline \multicolumn{7}{|l|}{ FX and Derivative Risk } \\
\hline FX loans to total loans & 28.2 & 26.8 & 27.7 & 30.1 & 33.4 & 34.4 \\
\hline FX liabilities to total liabilities & 40.6 & 42.4 & 42.7 & 49.2 & 48.4 & 55.1 \\
\hline
\end{tabular}

Sources: IMF FSI database; and IMF staff calculations.

1/ Billions of Canadian dollars. 
Table 7. Canada: Chartered Banks' Loans to Individuals, 2012-16

\begin{tabular}{llllll}
\hline 2012 & 2013 & 2014 & 2015 & 2016
\end{tabular}

\section{Canada}

Total loans to individuals

Of which: residential mortgages
2012

$$
2013
$$

(In billions of $C \$$ )

\section{Big 4 provinces}

Quebec

Total loans to individuals

Of which: residential mortgages

Ontario

Total loans to individuals

Of which: residential mortgages

Alberta

British Columbia
220

113

718

396

218

123

232

131

753

416

796

435

860

468

895

496

244

260

162
269

167
245

138

254

256

147

153 290

136
Total loans to individuals

Of which: residential mortgages

Total loans to individuals

Of which: residential mortgages

(Share of residential mortgages in total loans, in percent)

\section{Canada}

\section{Big 4 provinces}

Quebec

Ontario

Alberta

British Columbia
48.6

48.0

51.5

55.2

56.5

62.5
49.8

55.3

56.6

62.1
47.1

45.1

282

176

296

190 


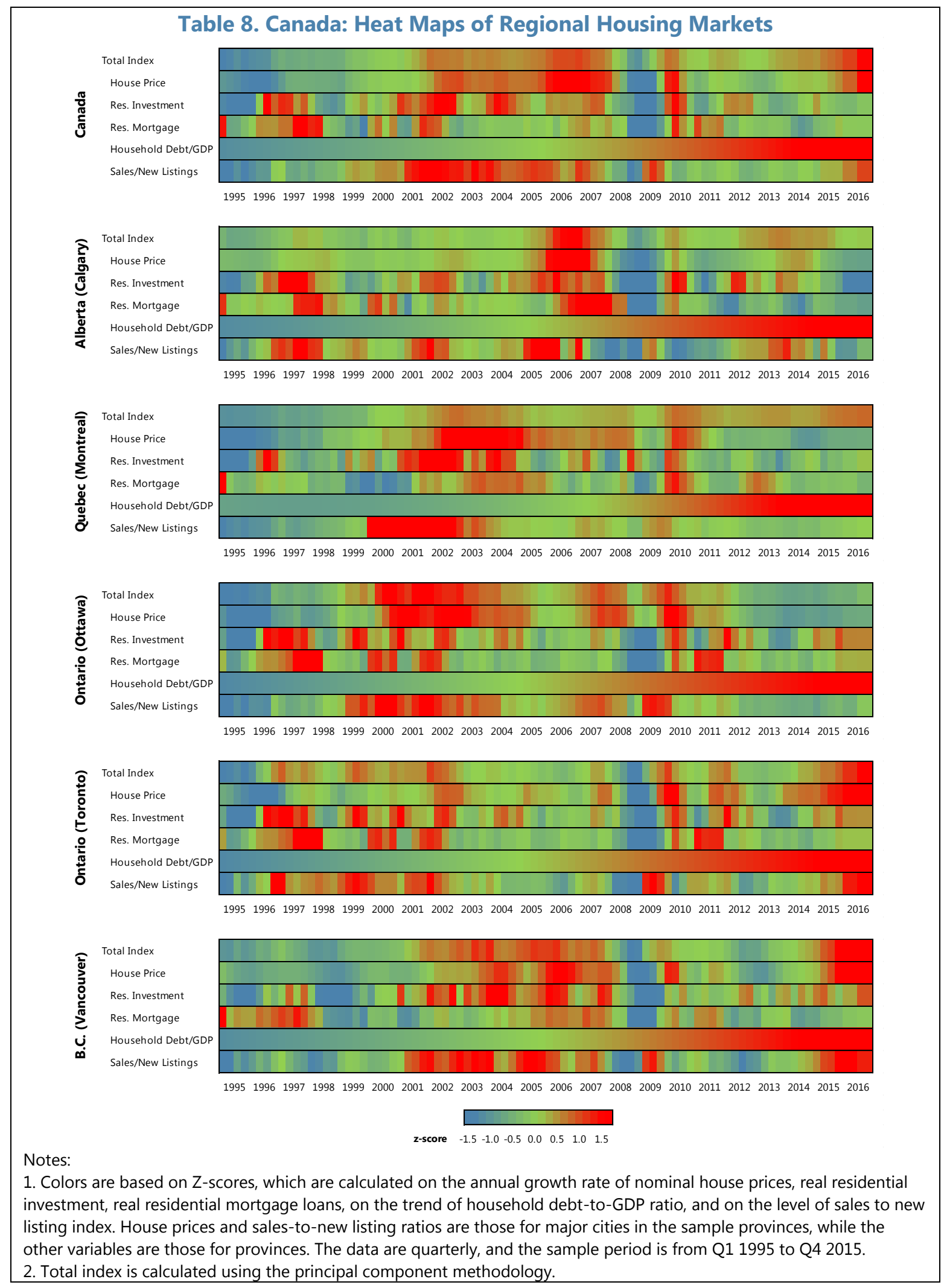


Table 9. Canada: Medium-Term Scenario 2014-22

(Percentage change, unless otherwise indicated)

\begin{tabular}{|c|c|c|c|c|c|c|c|c|c|}
\hline & \multirow[b]{2}{*}{2014} & \multirow[b]{2}{*}{2015} & \multirow[b]{2}{*}{2016} & \multicolumn{6}{|c|}{ Projections } \\
\hline & & & & 2017 & 2018 & 2019 & 2020 & 2021 & 2022 \\
\hline \multicolumn{10}{|l|}{ National Accounts in constant prices } \\
\hline Real GDP & 2.6 & 0.9 & 1.5 & 2.5 & 1.9 & 1.8 & 1.8 & 1.8 & 1.8 \\
\hline Q4/Q4 & 2.2 & 0.4 & 2.0 & 2.3 & 2.0 & 1.8 & 1.8 & 1.8 & 1.8 \\
\hline Net exports $1 /$ & 1.1 & 1.0 & 0.6 & -0.2 & 0.0 & 0.0 & 0.0 & 0.0 & 0.0 \\
\hline Final domestic demand & 1.9 & 0.3 & 1.0 & 2.7 & 1.9 & 1.8 & 1.8 & 1.8 & 1.7 \\
\hline Private consumption & 2.7 & 1.9 & 2.3 & 2.4 & 1.9 & 1.9 & 1.8 & 1.7 & 1.7 \\
\hline Public consumption & 0.8 & 1.5 & 2.0 & 2.7 & 1.4 & 1.0 & 1.1 & 1.3 & 1.1 \\
\hline Private fixed domestic investment & 1.8 & -6.2 & -3.9 & 1.9 & 2.2 & 2.8 & 2.7 & 2.6 & 2.7 \\
\hline Public investment & -4.2 & 4.5 & 1.1 & 11.3 & 3.2 & -0.2 & 0.6 & 0.8 & 0.9 \\
\hline Change in inventories 1 / & -0.3 & -0.3 & -0.3 & -0.1 & -0.1 & 0.0 & 0.0 & 0.0 & 0.0 \\
\hline Nominal GDP & 4.5 & 0.2 & 2.1 & 4.8 & 3.9 & 4.0 & 3.9 & 3.9 & 3.9 \\
\hline \multicolumn{10}{|l|}{ Employment and inflation } \\
\hline Unemployment rate $3 /$ & 6.9 & 6.9 & 7.0 & 6.7 & 6.6 & 6.5 & 6.5 & 6.5 & 6.5 \\
\hline Employment & 0.6 & 0.9 & 0.7 & 1.5 & 1.0 & 0.8 & 0.7 & 0.7 & 0.7 \\
\hline CPI inflation & 1.9 & 1.1 & 1.4 & 1.9 & 2.0 & 2.1 & 2.0 & 2.0 & 2.0 \\
\hline Core CPI inflation (y/y) & 1.8 & 2.2 & 1.9 & 1.6 & 2.0 & 2.1 & 2.0 & 2.0 & 2.0 \\
\hline GDP deflator & 1.9 & -0.8 & 0.6 & 2.2 & 1.9 & 2.1 & 2.1 & 2.1 & 2.1 \\
\hline Potential output growth & 2.1 & 1.6 & 1.5 & 1.5 & 1.6 & 1.7 & 1.8 & 1.8 & 1.9 \\
\hline Output gap 4/ & -0.4 & -1.0 & -1.1 & -0.1 & 0.3 & 0.4 & 0.4 & 0.4 & 0.3 \\
\hline \multicolumn{10}{|l|}{ Indicators of fiscal policies } \\
\hline Federal fiscal balance & 0.4 & 0.0 & -0.8 & -1.3 & -1.3 & -1.1 & -0.9 & -0.8 & -0.8 \\
\hline Billions of Can\$ & 8.2 & -0.6 & -17.0 & -27.0 & -27.8 & -24.6 & -21.4 & -20.5 & -19.7 \\
\hline General government fiscal balance 5/ & 0.0 & -1.1 & -1.9 & -2.2 & -2.0 & -1.7 & -1.5 & -1.4 & -1.2 \\
\hline Billions of Can\$ & -0.6 & -22.3 & -37.9 & -47.2 & -44.7 & -39.8 & -36.4 & -34.1 & -29.7 \\
\hline General government gross debt & 85.4 & 91.6 & 92.3 & 90.3 & 89.0 & 87.3 & 85.6 & 83.7 & 81.6 \\
\hline General government net debt & 27.2 & 25.2 & 27.6 & 25.6 & 24.3 & 22.7 & 20.9 & 19.0 & 16.9 \\
\hline Three-month treasury bill 3/ & 0.9 & 0.5 & 0.5 & 0.5 & 0.8 & 1.4 & 2.4 & 2.8 & 2.8 \\
\hline Ten-year government bond yield $3 /$ & 2.2 & 1.5 & 1.3 & 1.7 & 2.1 & 2.6 & 3.0 & 3.3 & 3.4 \\
\hline \multicolumn{10}{|l|}{ External indicators } \\
\hline Current account balance 2/ & -2.4 & -3.4 & -3.3 & -3.0 & -3.0 & -2.9 & -2.8 & -2.5 & -2.3 \\
\hline Merchandise trade balance $2 /$ & 0.2 & -1.2 & -1.3 & -1.1 & -1.2 & -1.2 & -1.1 & -0.9 & -0.7 \\
\hline Export volume & 5.7 & 3.7 & 0.5 & 1.5 & 2.8 & 3.1 & 3.2 & 3.3 & 3.2 \\
\hline Import volume & 2.3 & 0.3 & -1.2 & 2.4 & 2.8 & 3.1 & 2.9 & 3.0 & 3.0 \\
\hline Terms of trade & -1.3 & -6.9 & -2.0 & 1.8 & -0.4 & 0.1 & 0.3 & 0.4 & 0.4 \\
\hline Real effective exchange rate & -6.4 & -8.8 & -2.4 & $\ldots$ & $\ldots$ & $\ldots$ & $\ldots$ & $\ldots$ & $\ldots$ \\
\hline \multicolumn{10}{|l|}{ Saving and investment 2 / } \\
\hline Gross national saving & 22.2 & 20.4 & 19.6 & 19.9 & 20.0 & 20.1 & 20.4 & 20.8 & 21.0 \\
\hline General government & 3.6 & 2.9 & 2.4 & 1.8 & 1.9 & 2.0 & 2.0 & 2.0 & 2.0 \\
\hline Private & 18.6 & 17.5 & 17.2 & 18.1 & 18.1 & 18.2 & 18.4 & 18.8 & 19.0 \\
\hline Gross domestic investment & 24.7 & 23.8 & 22.9 & 22.9 & 23.0 & 23.1 & 23.2 & 23.3 & 23.4 \\
\hline Personal savings $6 /$ & 3.7 & 5.0 & 5.1 & 5.1 & 5.0 & 4.6 & 4.2 & 4.1 & 4.0 \\
\hline \multicolumn{10}{|l|}{ Memorandum Items } \\
\hline Nominal GDP (billions of Can\$) & 1,983 & 1,986 & 2,028 & 2,124 & 2,206 & 2,294 & 2,384 & 2,478 & 2,576 \\
\hline \multicolumn{10}{|c|}{ Sources: Haver Analytics; and IMF staff estimates. } \\
\hline \multicolumn{10}{|l|}{$\begin{array}{l}\text { 1/ Contribution to growth. } \\
\text { 2/ Percent of GDP. } \\
\text { 3/ Percent. } \\
\text { 4/ Percent of potential GDP. } \\
\text { 5/ Includes federal, provincial, territo } \\
\text { 6/ Percent of disposable income. }\end{array}$} \\
\hline
\end{tabular}




\section{Canada}

Foreign asset and liability position and trajectory

\section{Capital and}

financial

accounts:

flows and

policy

measures

FX intervention and reserves level
Background Canada's net international investment position (NIIP) declined from 21.7 percent of GDP in 2015 to 9.3 percent of GDP in 2016. This decline reflected net borrowing from abroad and valuation changes due to the stronger performance of the Canadian stock market relative to most major foreign stock markets. Gross external debt reached 116 percent of GDP, 5 percentage points of GDP higher than in 2015, with foreign portfolio investment accounting for most of this increase. About a third of external debt is short-term. The NIIP is projected to decline in the medium term in line with a reduction in the current account deficit.

Assessment. Despite rising external debt, Canada remains a net creditor to the rest of the world. Canada's foreign assets have a higher foreign currency component than its liabilities which provides a hedge against currency depreciation. The NIIP level and trajectory are sustainable.

\section{Background. Canada's current account (CA) balance recorded a marginal improvement from -3.4 percent of GDP in} 2015 to -3.3 percent of GDP in 2016. Higher merchandise trade deficit was offset by a slightly higher services trade balance due to stronger sales of commercial and travel services. Underlying the change in the CA was a worsening of the general government savings-investment balance by 0.6 percentage points of GDP (from -1 percent to - 1.6 percent of GDP), as the government embarked on fiscal expansion to support the economy. This was more than offset by an improvement of the private sector's balance by 0.7 percentage point (from -2.4 percent to -1.7 percent of GDP).

Assessment. The EBA estimates a CA norm of 0.5 percent of GDP, consistent with a cyclically adjusted CA gap of -3.1 percent of GDP for 2016. This gap has narrowed compared to last year, but still likely overstates the desirable external adjustment. Staff estimates the CA norm to be lower, at about -0.9 percent of GDP, with the CA gap between -2.6 and 0.6 percent of GDP. Staff adjusted the CA norm to take into account mainly the erosion in external competitiveness and productive capacity in the non-resource sector.1/

Background. The real effective exchange rate (REER) depreciated by 2 percent on an annual average basis between 2015 and 2016. This has been unwound more recently. As of May 2017, the REER has appreciated by 2.3 percent compared to the average for 2016.

Assessment. Both the EBA REER index and level approaches point to the currency being undervalued, by 10 and 20.5 percent respectively in 2016, which is different from the implied EBA CA results. In staff's view, the REER approaches overstate the extent of undervaluation, as they do not fully capture the structural factors behind Canada's export underperformance and the need to restore external competitiveness in non-resource sectors.2/ Consistent with the assessed CA gap, staff estimates that the real effective exchange rate is overvalued by about 2 to 10 percent relative to medium-term fundamentals and desirable policies.3/

Background. The CA deficit in 2016 has been financed by net portfolio inflows (7.3 percent of GDP). Non-resident investors mostly purchased corporate debt securities (44 percent of portfolio net inflows). Foreign acquisition of Canadian equities and government debt securities stood at 51 and 5 percent, respectively. In 2016 foreign direct investment recorded a higher net outflow of 2.1 percent of GDP (1.6 percent of GDP in 2015).

Assessment. Canada has a fully open capital account. Vulnerabilities are limited by a credible commitment to a floating exchange rate and, while the government is running fiscal deficits in the order of 1 percent of GDP in the near term, there is strong and credible commitment to fiscal consolidation over the medium term.

Background. Canada has a free-floating exchange rate regime, and has not intervened in the foreign exchange market since September 1998 (with the exception of participating in internationally concerted interventions). Canada has limited reserves but its central bank has standing swap arrangements with the U.S. Federal Reserve and four other major central banks (it has not drawn on these swap lines).

Assessment. Policies in this area are appropriate to the circumstances of Canada. The authorities are strongly committed to a floating regime which, together with the swap arrangement, reduces the need for reserve holding.
Overall Assessment

\section{Overall Assessment}

The external position in 2016 remained moderately weaker than implied by

medium-term fundamentals and desirable policies.

The depreciation of the currency over the past two years has helped improve

Canada's external competitiveness, but it will take time for the economy to adjust to structural shifts in the allocation of resources, restore lost production capacity, and address productivity

underperformance. Recent developments do not suggest a change in the assessment of the external position for 2016 .

In the medium term, the external position is expected to strengthen as non-energy exports gradually benefit from improved price competitiveness and investment in services and manufacturing capacity.

\section{Potential policy responses:}

Policies to boost Canada's non-energy exports include measures geared at improving labor productivity; investing in $R \& D$ and physical capital; promoting FDI; developing services exports; and diversifying Canada's export markets. The planned increase in public infrastructure investment should boost competitiveness, and improve the external position over time. A credible medium-term

consolidation plan for fiscal policy will also be necessary to support the external rebalancing. Maintaining tight

macroprudential policies to ensure

financial stability should also support private sector saving. 


\begin{tabular}{|l|l|}
\hline $\begin{array}{l}\text { Technical } \\
\text { Background } \\
\text { Notes }\end{array}$ & $\begin{array}{l}\text { 1/ This adjustment is consistent with staff's estimate of the CA in the medium-term macroeconomic framework and reflects the following key factors: (i) the } \\
\text { structural loss in trade competitiveness (see Agur, Itai, } 2016 \text { "Products and provinces: a disaggregated panel analysis of Canada's manufacturing exports", } \\
\text { WP/16/193, International Monetary Fund). A long period of low labor productivity growth and the appreciation of the Canadian dollar during the oil boom } \\
\text { worsened external competitiveness, depressed business investment outside the energy sector, and led to a decline in productive capacity in the non-resource } \\
\text { sector. (ii) the EBA does not capture the increasing attractiveness of Canadian assets to overseas investors as a "safe haven". } \\
\text { 2/ The approach also includes commodity terms of trade rather than oil prices as an explanatory variable, while Canada's REER has mirrored movements in oil } \\
\text { prices much more closely than its commodity terms of trade. } \\
\text { 3/ The semi-elasticity of the CA with respect to the REER is estimated at } 0.27 .\end{array}$ \\
\hline
\end{tabular}




\section{Annex II. Public Debt Sustainability Analysis}

The overall assessment is broadly unchanged from the 2016 Article IV staff report. Canada's public debt remains on a sustainable trajectory over the medium term. Under the baseline, after peaking at 92 percent in 2016, the ratio of gross debt to GDP will gradually decline to 82 percent by 2022, as real GDP growth picks up and fiscal consolidation proceeds gradually. Even under most stress scenarios, the debt ratio does not rise above 100 percent. Sizable financial assets (about 64 percent of GDP) provide an additional cushion. The net debt-to-GDP ratio stood at 28 percent in 2016 and is expected to fall below 20 percent by 2022.

\section{Baseline Scenario}

1. Under the staff's baseline macroeconomic scenario, the general government primary deficit is projected to increase to 1.5 percent of GDP in 2017 and thereafter, with fiscal consolidation, decline to 0.4 percent by 2022. The general government gross debt to GDP ratio is projected to start falling gradually from 2017, which reflects favorable interest rate and growth differentials - higher real GDP growth rates, combined with a moderate pace of increases in interest rates. By 2022, the general government gross debt-to-GDP ratio is expected to fall to 82 percent.

2. By the authorities' definition which includes a wider coverage of assets, net debt stood at 28 percent of GDP in 2016. If only highly-liquid assets (currency, deposits, and bonds) are included, the net debt-to-GDP ratio was higher at around 63 percent. The net debt ratio is expected decline from 28 percent to below 20 percent by 2021.

3. Grows financing needs at around 18 percent is relatively high but is manageable, as it is expected to hover within a range of 17-20 percent during the projection horizon.

\section{Stress tests}

- Primary balance shock. A deterioration of the primary balance of about one percent of GDP would raise the gross debt-to-GDP ratio by about 2 percentage points over the projection period. The sovereign risk premium is assumed to increase by 25 basis points for each one percent of GDP deterioration in the primary balance, resulting in higher gross financing needs of 1-2 percentage points of GDP compared to the baseline.

- Growth shock. A lower real GDP growth by one standard deviation for two years in 2018 and 2019 will reduce real GDP growth rates sharply to about 0-0.2 percent. This would lead to a sharp deterioration in the primary balance, reaching a $23 / 4$ percent deficit at its peak in 2019 . The gross debt-to-GDP ratio will approach nearly 95 percent of GDP in 2019, but would revert to a downward path over the projection period, as GDP growth recovers. Gross financing needs will also rise faster until 2019, about 3 percentage points higher than the baseline. 
- Interest rate shock. An increase in the sovereign risk premium by 200 basis points for two years would raise the effective interest rate $1 / 2-3 / 4$ percentage points higher than the baseline during the projection period. The impact on debt and gross financing needs are mild.

- Exchange rate shock. Given that about 90 percent of Canada's outstanding marketable debt instruments are in Canadian dollars, the fiscal impact of an exchange rate shock is minimal, even with the substantial exchange rate depreciation of about 23 percent (which Canada experienced in 2008).

- Stagnant growth scenario. Structurally weak growth in key advanced and emerging economies would reduce demand for Canadian exports. Canada's real GDP growth could fall below the baseline scenario by $1 / 4-1 / 2$ percentage points for the projection horizon. In this scenario, the gross debt-to-GDP ratio will not fall and stay at the current level.

- Housing market shock: Under this scenario, a severe recession that reduces real GDP growth by two standard deviation in 2018 (to minus 1.6 percent) and one standard deviation in 2019 (to 0.1 percent) could precipitate a sharp and unexpected housing market correction. Mortgage insurers could come under stress and would need to be partially bailed out. In this tail event, the government would be forced to increase its non-interest expenditures by 20 percent of government guarantees for mortgage insurers' borrowings (equivalent to 2 percent of GDP). The debt-to GDP ratio would rise to just below 100 percent of GDP while gross financing needs would reach 25 percent of GDP at its peak.

4. The sizable general government financial assets provide another layer of cushion against shocks. The general government's financial assets stood at about 64 percent of GDP in 2016, of which about 45 percent (29 percent of GDP) were highlyliquid assets (deposits, short-term papers, and bonds).

\section{Public debt has increased in recent years, reflecting the government's policy to fund public sector employee pension plans by issuing new debt. General} government debt as reported here does not

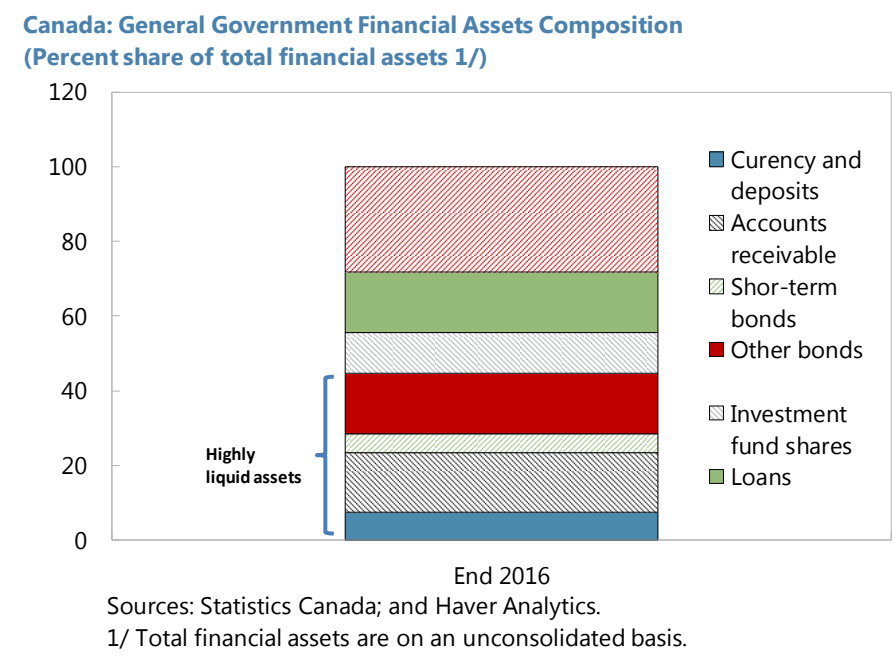

include unfunded pension liabilities. The vast majority of advanced economies do not report unfunded pension liabilities and as such they are excluded from measures of public sector debt to allow for consistent international comparison. General government debt, including unfunded pension liabilities, would be 109 percent of GDP on a gross basis, and 44 percent of GDP on a net basis in 2016. 


\section{Canada Public DSA Risk Assessment}

\section{Heat Map}

Debt level ${ }^{1 /}$

Debt profile ${ }^{3 /}$

\begin{tabular}{|c|c|c|c|c|}
\hline $\begin{array}{c}\text { Real GDP } \\
\text { Growth Shock }\end{array}$ & $\begin{array}{c}\text { Primary } \\
\text { Balance Shock }\end{array}$ & $\begin{array}{c}\text { Real Interest } \\
\text { Rate Shock }\end{array}$ & $\begin{array}{c}\text { Exchange Rate } \\
\text { Shock }\end{array}$ & $\begin{array}{c}\text { Contingent } \\
\text { Liability shock }\end{array}$ \\
\hline $\begin{array}{c}\text { Real GDP } \\
\text { Growth Shock }\end{array}$ & $\begin{array}{c}\text { Primary } \\
\text { Balance Shock }\end{array}$ & $\begin{array}{c}\text { Real Interest } \\
\text { Rate Shock }\end{array}$ & $\begin{array}{c}\text { Exchange Rate } \\
\text { Shock }\end{array}$ & $\begin{array}{c}\text { Contingent } \\
\text { Liability Shock }\end{array}$ \\
\hline $\begin{array}{c}\text { Market } \\
\text { Perception }\end{array}$ & $\begin{array}{c}\text { External } \\
\text { Financing } \\
\text { Requirements }\end{array}$ & $\begin{array}{c}\text { Change in the } \\
\text { Share of Short- Held by Non- } \\
\text { Term Debt }\end{array}$ & $\begin{array}{c}\text { Public Debt } \\
\text { Residents }\end{array}$ & $\begin{array}{c}\text { Currency } \\
\text { Debt }\end{array}$ \\
\hline
\end{tabular}

\section{Evolution of Predictive Densities of Gross Nominal Public Debt}

(in percent of GDP)

Baseline Percentiles: $\quad$ 10th-25th $\quad$ 25th-75th $\quad$ 75th-90th

Symmetric Distribution

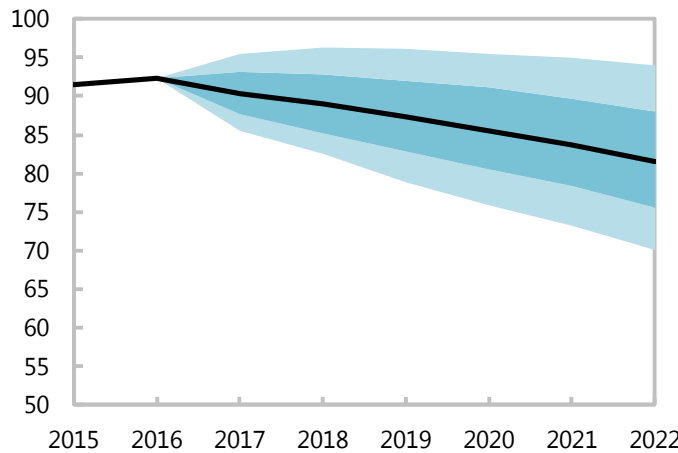

Restricted (Asymmetric) Distribution

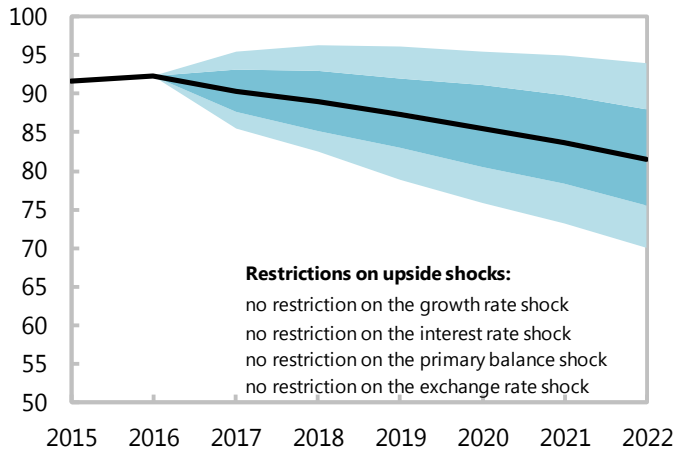

Debt Profile Vulnerabilities

(Indicators vis-à-vis risk assessment benchmarks, in 2016)

- - Lower early warning

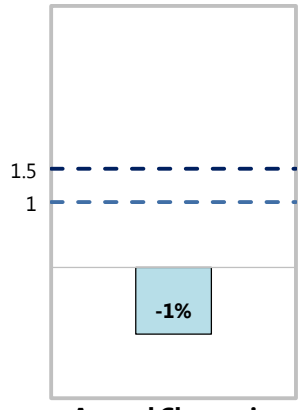

Annual Change in

Short-Term Public

Debt

(in percent of total)

- - Upper early warning

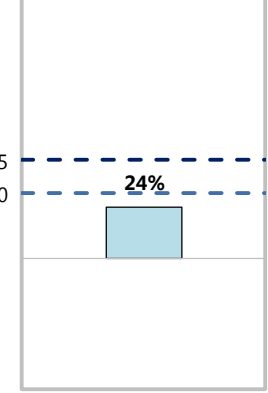

Public Debt Held by Non-Residents

(in percent of total)

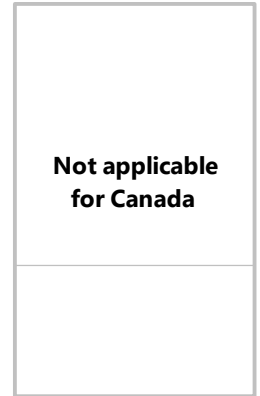

Public Debt in Foreign Currency

(in percent of total)

Source: IMF staff.

1 / The cell is highlighted in green if debt burden benchmark of $85 \%$ is not exceeded under the specific shock or baseline, yellow if exceeded under specific shock but not baseline, red if benchmark is exceeded under baseline, white if stress test is not relevant.

$2 /$ The cell is highlighted in green if gross financing needs benchmark of $20 \%$ is not exceeded under the specific shock or baseline, yellow if exceeded under specific shock but not baseline, red if benchmark is exceeded under baseline, white if stress test is not relevant.

3 / The cell is highlighted in green if country value is less than the lower risk-assessment benchmark, red if country value exceeds the upper risk-assessment benchmark, yellow if country value is between the lower and upper risk-assessment benchmarks. If data are unavailable or indicator is not relevant, cell is white. Lower and upper risk-assessment benchmarks are:

400 and 600 basis points for bond spreads; 17 and 25 percent of GDP for external financing requirement; 1 and 1.5 percent for change in the share of short-term debt; 30 and 45 percent for the public debt held by non-residents.

4/ Long-term bond spread over U.S. bonds, an average over the last 3 months, 09-Mar-17 through 07-Jun-17.

5/ External financing requirement is defined as the sum of current account deficit, amortization of medium and long-term total external debt, and short-term total external debt at the end of previous period. 


\section{Canada Public Sector Debt Sustainability Analysis (DSA) - Baseline Scenario}

(in percent of GDP unless otherwise indicated)

Debt, Economic and Market Indicators ${ }^{1 /}$

\begin{tabular}{|c|c|c|}
\hline \multicolumn{3}{|c|}{ Actual } \\
\hline $2006-2014^{2}$ & 2015 & 2016 \\
\hline 78.1 & 91.6 & 92.3 \\
\hline 16.2 & 15.7 & 17.5 \\
\hline 25.4 & 25.2 & 27.6 \\
\hline 1.7 & 0.9 & 1.5 \\
\hline 2.1 & -0.8 & 0.6 \\
\hline 3.9 & 0.2 & 2.1 \\
\hline 5.0 & 3.6 & 3.3 \\
\hline
\end{tabular}

\begin{tabular}{rrrrrr}
\multicolumn{7}{c}{ Projections } \\
\hline 2017 & 2018 & 2019 & 2020 & 2021 & 2022 \\
\hline 90.3 & 89.0 & 87.3 & 85.5 & 83.6 & 81.6 \\
16.4 & 19.0 & 19.8 & 18.5 & 18.2 & 18.0 \\
25.6 & 24.3 & 22.7 & 20.9 & 19.0 & 16.9 \\
& & & & & \\
2.5 & 1.9 & 1.8 & 1.8 & 1.8 & 1.8 \\
2.2 & 1.9 & 2.1 & 2.1 & 2.1 & 2.1 \\
4.8 & 3.9 & 4.0 & 3.9 & 3.9 & 3.9 \\
3.0 & 3.3 & 3.3 & 3.4 & 3.6 & 3.6 \\
\hline
\end{tabular}

As of June 07, 2017
Sovereign Spreads
$\begin{array}{lll}\text { EMBIG (bp) 3/ } & -77 \\ \text { 5Y CDS (bp) } & \ldots \\ & \\ & \\ \text { Ratings } & \text { Foreign } & \text { Local } \\ \text { Moody's } & \text { Aaa } & \text { Aaa } \\ \text { S\&Ps } & \text { AAA } & \text { AAA } \\ \text { Fitch } & \text { AAA } & \text { AAA }\end{array}$

Contribution to Changes in Public Debt

Actual

Change in gross public sector debt

Identified debt-creating flows

Primary deficit

Primary (noninterest) revenue and gra 36.1

Primary (noninterest) expenditure $\quad 36.9$

Automatic debt dynamics ${ }^{5 /}$

Interest rate/growth differential ${ }^{6 /} \quad 0.8$

Of which: real interest rate $\quad 2.1$

Of which: real GDP growth $\quad-1.3$

Exchange rate depreciation ${ }^{7 /}$

Other identified debt-creating flows

Residual, including asset changes ${ }^{8 /}$

\begin{tabular}{|c|c|c|}
\hline \multicolumn{3}{|c|}{ Actual } \\
\hline 2006-2014 & 2015 & 2016 \\
\hline 1.6 & 6.1 & 0.7 \\
\hline 1.5 & 4.9 & 2.0 \\
\hline 0.7 & 0.5 & 1.1 \\
\hline gra 36.1 & 36.6 & 36.8 \\
\hline 36.9 & 37.2 & 37.9 \\
\hline 0.8 & 4.4 & 0.9 \\
\hline 0.8 & 3.0 & 1.1 \\
\hline 2.1 & 3.8 & 2.4 \\
\hline-1.3 & -0.8 & -1.3 \\
\hline 0.0 & 1.4 & -0.2 \\
\hline 0.0 & 0.0 & 0.0 \\
\hline 0.1 & 1.3 & -1.2 \\
\hline
\end{tabular}

Projections

\begin{tabular}{|c|c|c|c|c|c|c|c|}
\hline 2017 & 2018 & 2019 & 2020 & 2021 & 2022 & cumulative & debt-stabilizing \\
\hline-2.0 & -1.3 & -1.6 & -1.8 & -1.9 & -2.1 & -10.7 & primary \\
\hline 0.0 & 1.0 & 0.6 & 0.4 & 0.3 & 0.1 & 2.6 & balance ${ }^{9 /}$ \\
\hline
\end{tabular}

$\begin{array}{lllllll}1.5 & 1.5 & 1.2 & 0.9 & 0.6 & 0.4 & 6.1\end{array}$

$\begin{array}{lllllll}36.6 & 36.4 & 36.5 & 36.5 & 36.6 & 36.6 & 219.3\end{array}$

$\begin{array}{lllllll}38.1 & 38.0 & 37.7 & 37.4 & 37.2 & 37.0 & 225.4\end{array}$

$\begin{array}{lllllll}-1.5 & -0.5 & -0.5 & -0.4 & -0.3 & -0.2 & -3.6\end{array}$

$\begin{array}{lllllll}-1.5 & -0.5 & -0.5 & -0.4 & -0.3 & -0.2 & -3.6\end{array}$

$\begin{array}{lllllll}0.7 & 1.2 & 1.0 & 1.1 & 1.2 & 1.2 & 6.3\end{array}$

$\begin{array}{rrrrrrr}-2.2 & -1.7 & -1.6 & -1.5 & -1.5 & -1.4 & -9.9\end{array}$

$\begin{array}{lllllll}\ldots & \ldots & \ldots & \ldots & \ldots & \ldots & \ldots\end{array}$

$\begin{array}{ccccccc}0.0 & 0.0 & 0.0 & 0.0 & 0.0 & 0.0 & 0.0\end{array}$

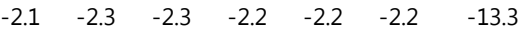

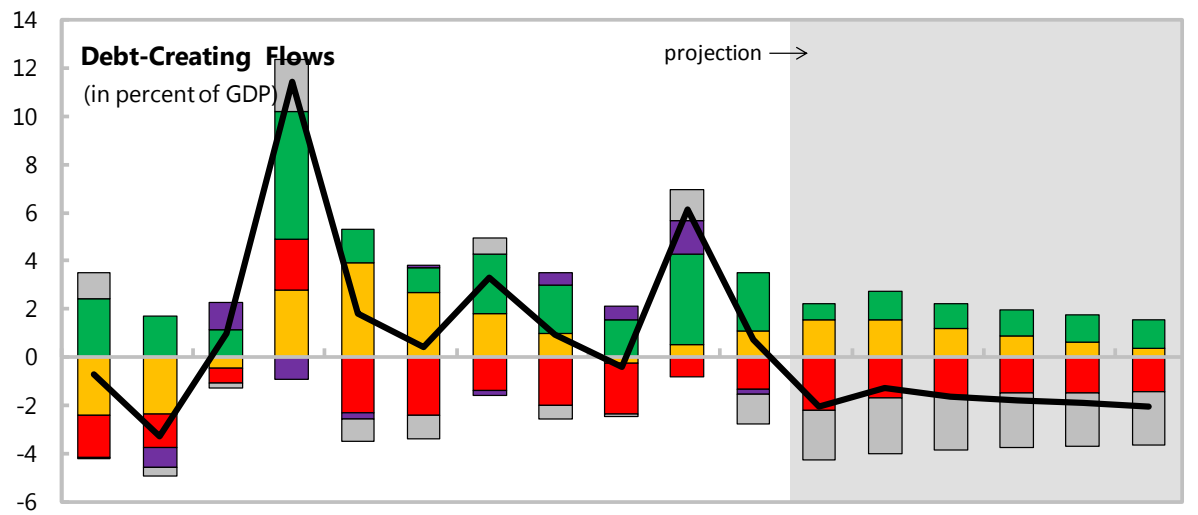

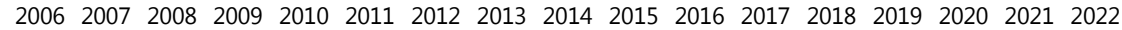

$\square$ Primary deficit

$\square$ Exchange rate depreciation

Change in gross public sector debt

\section{$\square$ Real GDP growth}

$\square$ Other debt-creating flows

$\square$ Real interest rate

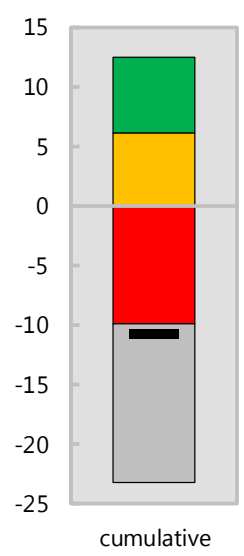

Source: IMF staff.

$1 /$ Public sector is defined as general government.

2/ Based on available data.

3/ Long-term bond spread over U.S. bonds.

4/ Defined as interest payments divided by debt stock (excluding guarantees) at the end of previous year

$5 /$ Derived as $[(r-\pi(1+g)-g+a e(1+r)] /(1+g+\pi+g \pi))$ times previous period debt ratio, with $r=$ interest rate; $\pi$ = growth rate of GDP deflator; $g=$ real GDP growth rate;

$\mathrm{a}=$ share of foreign-currency denominated debt; and $\mathrm{e}=$ nominal exchange rate depreciation (measured by increase in local currency value of U.S. dollar).

6 / The real interest rate contribution is derived from the numerator in footnote 5 as $r-\pi(1+g)$ and the real growth contribution as $-g$.

$7 /$ The exchange rate contribution is derived from the numerator in footnote 5 as ae( $1+r)$.

8/ Includes asset changes and interest revenues (if any). For projections, includes exchange rate changes during the projection period.

9/ Assumes that key variables (real GDP growth, real interest rate, and other identified debt-creating flows) remain at the level of the last projection year.

CInternational Monetary Fund. Not for Redistribution 


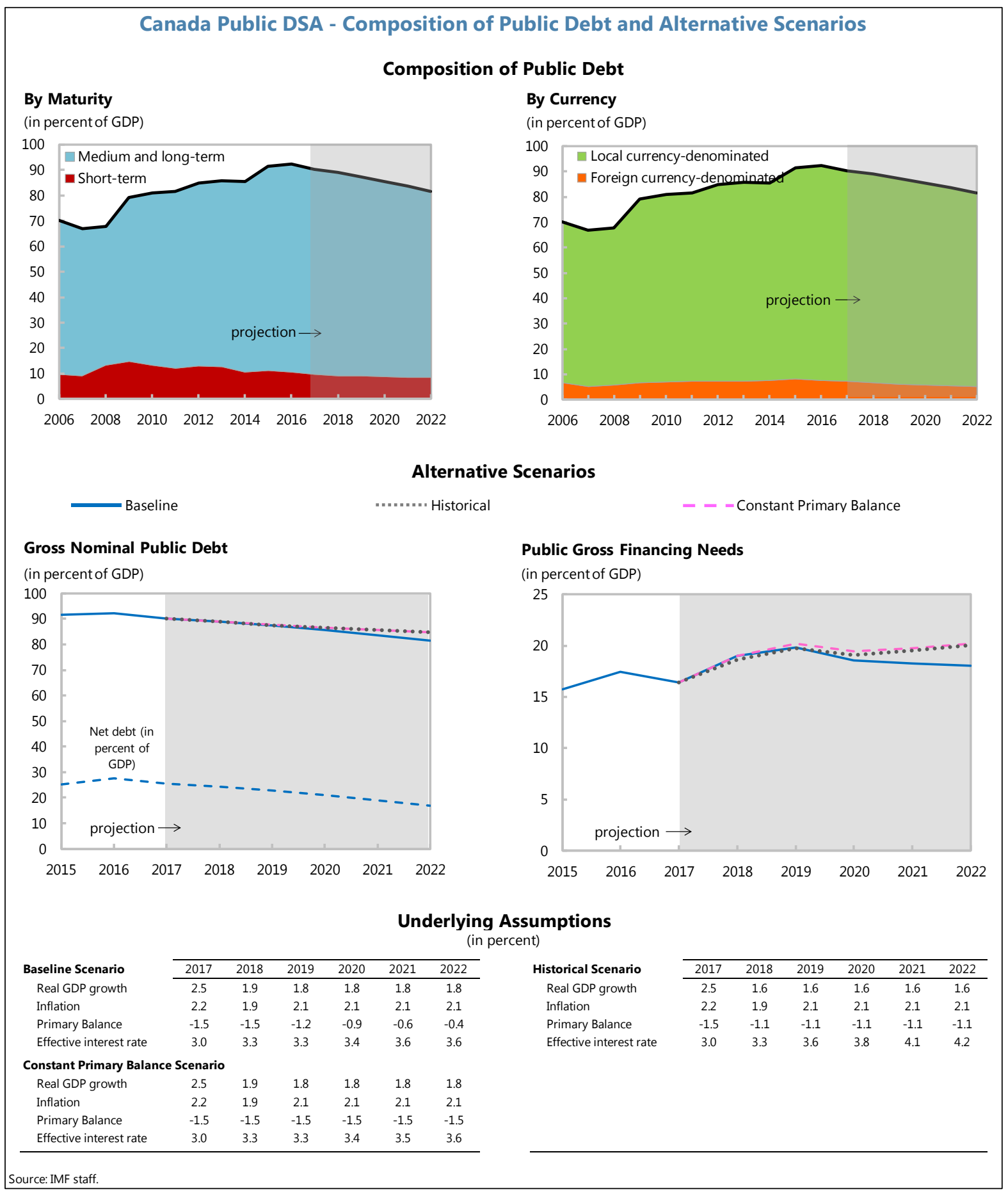




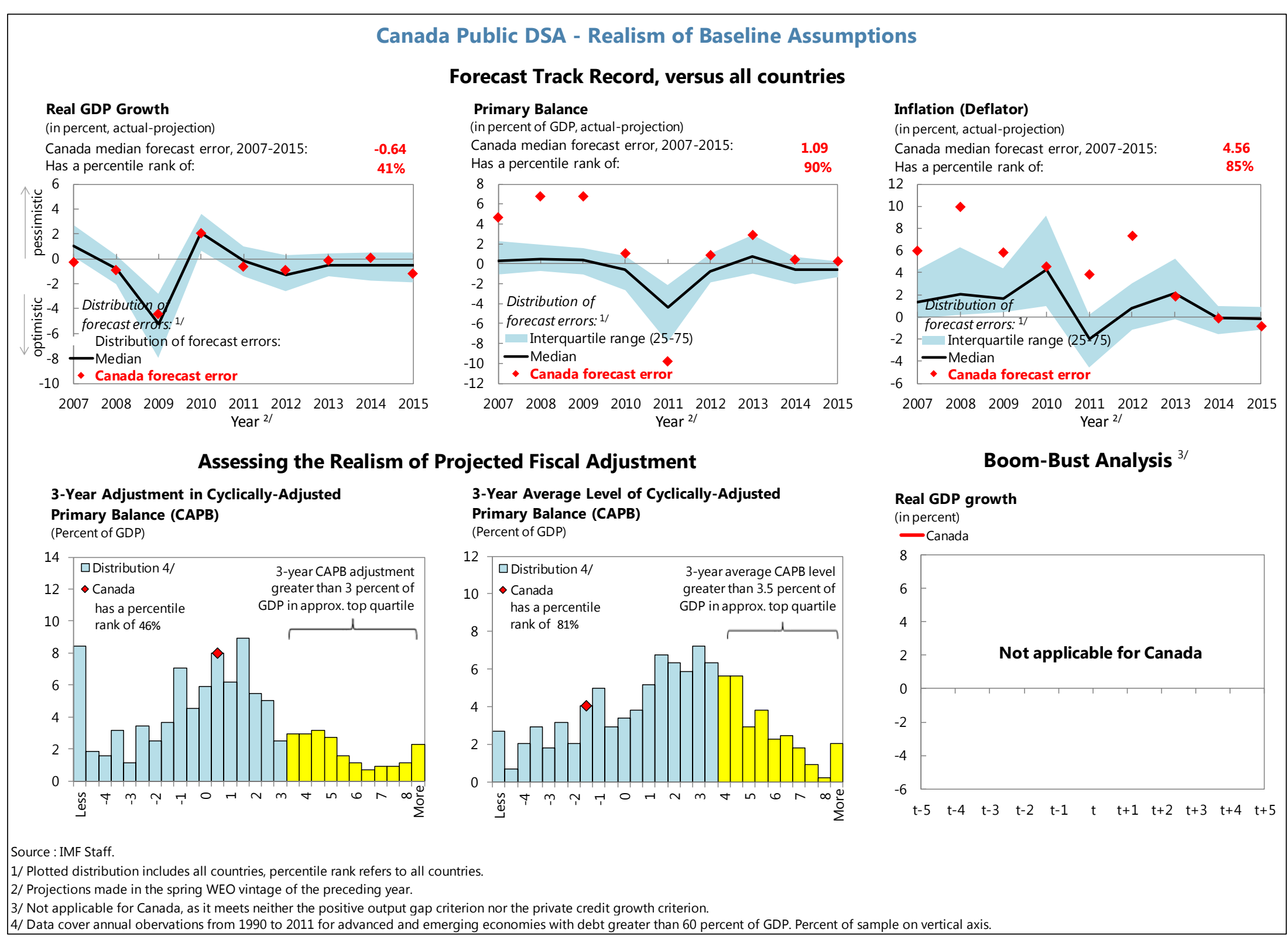

CInternational Monetary Fund. Not for Redistribution 


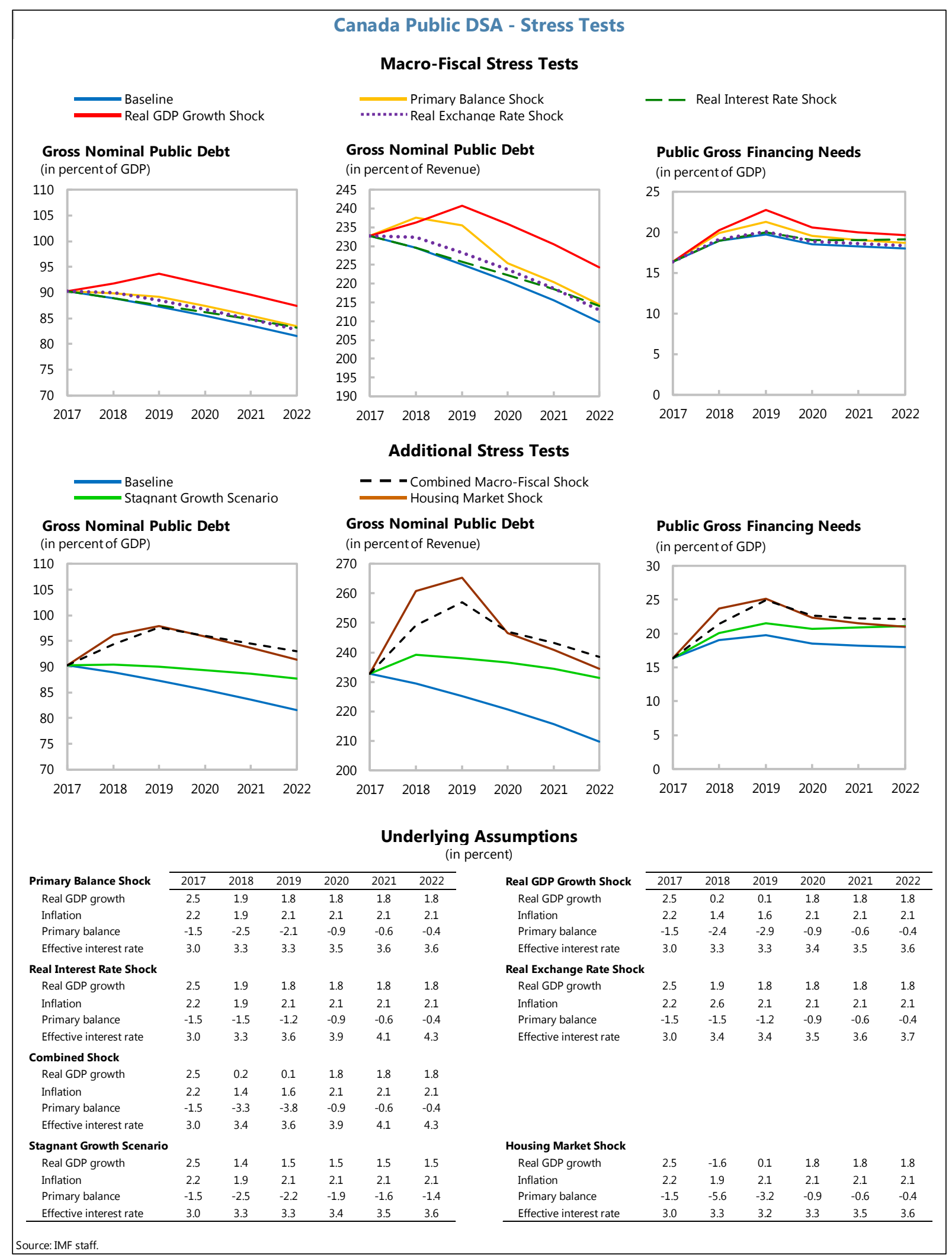




\section{Annex III. Canada: Housing-Related Measures to Safeguard Financial Stability}

\begin{tabular}{|c|c|}
\hline $\begin{array}{l}\text { October } 2008 \\
\text { (announced in July } \\
\text { 2008) }\end{array}$ & $\begin{array}{l}\text { Maximum amortization for new government-backed insured mortgages was lowered (from } 40 \text { to } \\
35 \text { years) } \\
\text { Maximum LTV for new mortgages was reduced (from } 100 \text { percent to } 95 \text { percent) } \\
\text { Minimum credit score requirement (of } 620 \text { ) was introduced. } \\
\text { Maximum of } 45 \text { percent total debt service ratio (the amount of gross income that is spent on } \\
\text { servicing debt and housing-related expenses such as heat or condo fees) was introduced. } \\
\text { Loan documentation standards strengthened to ensure reasonableness of property value and of } \\
\text { the borrower's sources and level of income }\end{array}$ \\
\hline $\begin{array}{l}\text { April } 2010 \text { (announced } \\
\text { in February 2010) }\end{array}$ & $\begin{array}{l}\text { Maximum LTV for insured refinanced mortgages was lowered (from } 95 \text { percent to } 90 \text { percent) } \\
\text { Minimum down payment on properties not occupied by owner was raised (from } 5 \text { percent to } 20 \\
\text { percent) } \\
\text { More stringent eligibility criteria were introduced (all borrowers are required to meet the standards } \\
\text { for a five-year fixed-rate mortgage, even if they choose a mortgage with a variable interest rate } \\
\text { and shorter term) }\end{array}$ \\
\hline $\begin{array}{l}\text { March } 2011 \\
\text { (announced in January } \\
\text { 2011) }\end{array}$ & $\begin{array}{l}\text { Maximum amortization for new government-backed insured mortgages was lowered (from } 35 \text { to } \\
30 \text { years) } \\
\text { Maximum LTV for refinanced mortgages was lowered (from } 90 \text { percent to } 85 \text { percent) } \\
\text { Government-backed insurance on non-amortizing lines of credit secured by houses (HELOCs) } \\
\text { withdrawn in April }\end{array}$ \\
\hline $\begin{array}{l}\text { July } 2012 \text { (announced } \\
\text { in June 2012) }\end{array}$ & $\begin{array}{l}\text { Maximum amortization for new government-backed insured mortgages was lowered (from } 30 \text { to } \\
25 \text { years) } \\
\text { Maximum LTV for refinanced mortgages was lowered (from } 85 \text { percent to } 80 \text { percent) } \\
\text { Maximum gross debt service ratio and maximum total debt service ratio were capped at } 39 \text { percent } \\
\text { and } 44 \text { percent, respectively } \\
\text { Government-backed insured mortgages limited to homes with a purchase price of less than Can } \$ 1 \\
\text { million. }\end{array}$ \\
\hline $\begin{array}{l}\text { May } 2014 \text { (announced } \\
\text { in February 2014) }\end{array}$ & Mortgage insurance premiums were raised \\
\hline $\begin{array}{l}\text { June } 2015 \text { (announced } \\
\text { in April 2015) }\end{array}$ & Mortgage insurance premiums were raised \\
\hline $\begin{array}{l}\text { February } 2016 \\
\text { (announced in } \\
\text { December 2015) }\end{array}$ & $\begin{array}{l}\text { The minimum down payment for new insured mortgages increased from } 5 \text { to } 10 \text { percent for the } \\
\text { portion of the house price above } \$ 500,000 \text {. The } 5 \text { percent minimum down payment for properties } \\
\text { up to } \$ 500,000 \text { remained unchanged }\end{array}$ \\
\hline
\end{tabular}

CInternational Monetary Fund. Not for Redistribution 
Table 1. Changes in Mortgage Insurance Rules (concluded)

October 17, 2016

(announced on October

3, 2016)

November 30, 2016 (announced on October

3, 2016)
To ensure uniform rules for all insured mortgages, all new mortgage borrowers with a down payment of less than 20 percent and seeking mortgage insurance were required to qualify at the posted rate for a conventional mortgage for a five-year term or the contract rate, whichever is higher.

The standards for low-ratio mortgage portfolio insurance were tightened to become uniform with those for insured high-ratio mortgages. 
Table 2. Canada: Other Housing Finance Related Regulatory Measures

\begin{tabular}{|c|c|}
\hline $\begin{array}{l}\text { January 2013, (announced in } \\
\text { June 2011) }\end{array}$ & $\begin{array}{l}\text { Protection of Residential Mortgage Hypothenar Insurance Act (PRMHIA) and amendments to } \\
\text { the National Housing Act assented } \\
\text { - Formalizes the rules for government-backed mortgage insurance and other existing } \\
\text { arrangements with private mortgage insurers } \\
\text { - Provision for the Minister of Finance to charge fees to compensate the Government for its } \\
\text { exposure to risk represented by loan insurance }\end{array}$ \\
\hline March 2012 & $\begin{array}{l}\text { Economic Action Plan } 2012 \text { announcements } \\
\text { - Canadian banks prohibited from issuing covered bonds backed by government-insured } \\
\text { mortgages (sets strong eligibility criteria for mortgages in the cover pool) } \\
\text { - CMHC designated as administrator of the covered bond framework } \\
\text { - CMHC's mandate was enhanced to include financial stability as an objective of CMHC's } \\
\text { commercial activities } \\
\text { - CMHC commercial activities subject to OSFI examination }\end{array}$ \\
\hline June 2012 & $\begin{array}{l}\text { Guideline on Sound Residential Mortgage Underwriting Practices (B-20) } \\
\text { - A guideline for residential mortgage underwriting practices and procedures was issued by } \\
\text { OSFI (including assessment of borrower's background and demonstrated willingness to service } \\
\text { debt payment in a timely manner, assessment of borrower's capacity to service debt, } \\
\text { assessment of property value/collateral, effective credit and counterparty risk management, } \\
\text { comprehensive residential mortgage underwriting policy) } \\
\text { - Maximum LTV on the revolving portion of HELOCs cut (from } 80 \text { to } 65 \text { percent) } \\
\text { - Stated Income mortgages were no longer allowed without some verification of income }\end{array}$ \\
\hline $\begin{array}{l}\text { January } 2015 \text { (announced in } \\
\text { September 2014) }\end{array}$ & $\begin{array}{l}\text { Revised Minimum Capital Test Guideline for property and casualty insurers } \\
\text { - The guideline introduced new and updated risk factors and margins plus a revised definition } \\
\text { of available capital }\end{array}$ \\
\hline May 15,2015 & $\begin{array}{l}\text { Amendments to PRMHIA. Substitution of loans in portfolio insurance pools was prohibited to } \\
\text { increase market discipline in residential lending and reduce taxpayer exposure to the housing } \\
\text { sector }\end{array}$ \\
\hline
\end{tabular}


Table 2. Other Housing Finance Related Regulatory Measures (concluded)

\begin{tabular}{|c|c|}
\hline $\begin{array}{l}\text { June } 30,2015, \text { full } \\
\text { implementation (announced } \\
\text { in November 2014) }\end{array}$ & $\begin{array}{l}\text { Residential Mortgage Insurance Underwriting Practices and Procedures (Guideline B21) was } \\
\text { issued. This guideline: } \\
\text { - } \quad \text { Outlines OSFI's expectations concerning mortgage insurers' governance and internal } \\
\text { risk management practices } \\
\text { - Outlines principles for mortgage insurers' own internal underwriting operations, } \\
\text { including setting prudent requirements for lenders and applying appropriate due diligence to } \\
\text { lenders' practices } \\
\text { - Enhances disclosure requirements, which will support greater transparency, clarity } \\
\text { and public confidence in mortgage insurers' residential mortgage insurance underwriting } \\
\text { practices }\end{array}$ \\
\hline December 11, 2015 & $\begin{array}{l}\text { CMHC announced changes to its securitization programs } \\
\text { - Changes in the guarantee fee schedule (effective July } 1,2016) \text {. Fees were raised for large } \\
\text { MBS issuers } \\
\text { - For 2016, the Minister of Finance authorized } \$ 105 \text { billion for NHA MBS and } \$ 40 \text { billion for } \\
\text { CMB. }\end{array}$ \\
\hline $\begin{array}{l}\text { November } 2016 \text { (announced } \\
\text { in December 2015) }\end{array}$ & $\begin{array}{l}\text { OSFI updated the regulatory capital requirements for residential mortgages: } \\
\text { - OSFI imposed a risk-sensitive floor for one of the model inputs (losses in the event of } \\
\text { default) that were tied to increases in local property prices and/or to house prices that are high } \\
\text { relative to borrower incomes } \\
\text { - For federally regulated private mortgage insurers, OSFI introduced a new standardized } \\
\text { approach updating the capital requirements for mortgage guarantee insurance risk. It requires } \\
\text { more capital when house prices are high relative to borrower incomes }\end{array}$ \\
\hline
\end{tabular}

\section{CInternational Monetary Fund. Not for Redistribution}




\section{Annex IV. Key Findings from Canada's Detailed Assessment on AML/CFT $^{1}$}

At the request of the Canadian authorities, Fund staff assessed Canada's anti-money laundering and combating the financing of terrorism (AML/CFT) regime against the 2012 Financial Action Task Force (FATF) Recommendations in November 2015. In line with the 2013 assessment methodology common to all AML/CFT assessor bodies, the assessment established (i) the level of technical compliance of Canada's legal and institutional framework with the FATF Recommendations, and (ii) the extent to which Canada's AML/CFT regime is effective in achieving the 11 outcomes set out in the methodology as being central to an effective AML/CFT. Staff's detailed assessment report was adopted by the FATF and the Asia/Pacific Group on Money Laundering (APG) as Canada's mutual evaluation report under the current standard, respectively in June 2016 and in September 2016, and published on the Fund, the FATF and the APG websites. ${ }^{2}$

\section{Key findings and recommendations}

\section{Technical Compliance: Canada's AML/CFT legal and institutional framework is} comprehensive, but important deficiencies nevertheless remain. Canada was found to comply fully or largely with 29 out of the FATF's 40 Recommendations (table 1). The money laundering offense, in particular, is fully in line with the standard, and the terrorist financing offense as well as the customer due diligence obligations imposed on financial institutions largely meet the standard. Obligations imposed on the nonfinancial businesses and professions designated by the standard, however, are deficient in several areas. The fact that AML/CFT obligations are inoperative for legal counsels, legal firms and Quebec notaries is a significant concern.

\begin{tabular}{|c|c|c|c|}
\hline \multicolumn{4}{|l|}{ Table 1. Technical Compliance } \\
\hline Canada's Technical Compliance with the FATF Recommendations & FATF Rec. & C or LC ${ }^{1}$ & $\mathrm{PC}$ or $\mathrm{NC}^{2}$ \\
\hline AML/CFT Policies and Coordination & R.1-2 & 2 & - \\
\hline Money Laundering and Confiscation & R.3-4 & 2 & - \\
\hline Terrorist Financing and Financing of Proliferation & R.5-8 & 4 & - \\
\hline Preventive Measures & R.9-23 & 8 & 7 \\
\hline Transparency and Beneficial Ownership or Legal Persons and Arrangements & R.24-25 & - & 2 \\
\hline $\begin{array}{l}\text { Powers and Responsibilities of Competent Authorities and Other } \\
\text { Institutional Measures }\end{array}$ & R.26-35 & 8 & 2 \\
\hline International Cooperation & R.36-40 & 5 & - \\
\hline Total & & 29 & 11 \\
\hline
\end{tabular}

\footnotetext{
1 Prepared by LEG's Financial Integrity Group.

${ }^{2}$ As a member of both the FATF and APG (the FATF-style regional body for the Asia/Pacific), Canada is subject to both bodies' peer review. The full assessment report may be found at: as well as on the FATF and APG websites.
} 
2. Effectiveness: Canada has a strong AML/CFT regime which is achieving good results in some areas, but requires several improvements to be fully effective (table 2). Canada faces important money laundering and, to a lesser extent, terrorist financing risks and has put several mitigating measures in place. The assessment found that the AML/CFT regime is comprehensive and presents several characteristics of an effective system in addressing these risk, but in some areas, major to fundamental improvements are necessary in the legal framework and its implementation to achieve higher levels of effectiveness.

- The authorities notably achieved a substantial level of effectiveness in terms of understanding the risks, international cooperation, AML/CFT supervision, and in the prevention, investigation and prosecution of terrorist financing activities (Immediate Outcomes 1,2, 3, 9 and 10). The Canadian authorities conducted a comprehensive assessment of the country's inherent money laundering and terrorist financing (ML/TF) risks in 2015, and have a good understanding of most of the risks. The AML/CFT regime covers all high-risk areas, except legal counsels, legal firms and Quebec notaries (because the Supreme Court declared AML/CFT measures inoperative in their respect). Domestic AML/CFT cooperation and coordination between competent authorities are generally good, both at the policy and operational levels. Canada also makes an effective use of the framework for international cooperation in AML/CFT matters. Financial institutions and designated sectors are generally subject to risk-sensitive AML/CFT supervision, but supervision of the real estate and dealers in previous metals and stones sectors is not entirely commensurate to the risks in those sectors. TF-related targeted financial sanctions are adequately implemented by financial institutions but not by designated non-financial sectors. Charities are monitored on a risk basis.

Assessors concluded that Canada needed to make moderate improvements to increase its effectiveness in these areas.

- Major improvements are needed to ensure that reporting entities adequately apply AML/CFT preventive measures, that financial intelligence is sufficiently used, and law enforcement efforts are commensurate with Canada's risks (Immediate Outcomes 4, 6, 7, and 8). Financial institutions generally apply preventive measures commensurate with the ML/TF risks that they face. Designated businesses and professions, however, are less effective in that respect. While financial intelligence is used to some extent to investigate predicate crimes and TF activities, it is used to a much more limited extent to pursue ML. Canada's financial intelligence unit, FINTRAC, receives a wide range of information, which it uses adequately, but some factors limit the scope and depth of the analysis that it may conduct, in particular, the fact that FINTRAC is not authorized to request additional information from any reporting entity. While Canada has achieved some success in pursuing $\mathrm{ML}$, overall, law enforcement results are not commensurate with country's ML risk, and asset recovery is low. Canada achieved a moderate level of effectiveness in these areas, and major improvements are needed. 
- TF and proliferation financing (PF) financial sanctions (Immediate outcome 11). Canada's Iran and North Korea sanction regime is comprehensive, and some success has been achieved in freezing funds of designated individuals; there is no mechanism to monitor compliance with PFrelated targeted financial sanctions. Canada demonstrated a moderate level of effectiveness in this area, and major improvements are needed to ensure the system is fully effective.

- Canadian legal persons are at high risk of misuse for ML/TF purposes, and that risk is not mitigated in practice (Immediate outcome 5). Canada achieved a low level of effectiveness in terms of transparency of the beneficial ownership of legal persons and arrangements. Thus, fundamental improvements are needed to ensure that information on beneficial owners of legal persons and arrangements is available to the authorities without impediments.

Table 2. Effectiveness Ratings

\begin{tabular}{|c|c|c|c|c|c|}
\hline & & High & Substantial & Moderate & Low \\
\hline IO.1 & Risk, policy and coordination & & $x$ & & \\
\hline IO.2 & International cooperation & & $\mathrm{x}$ & & \\
\hline IO.3 & Supervision & & $\mathrm{x}$ & & \\
\hline IO.4 & Preventive measures & & & $\mathrm{x}$ & \\
\hline IO.5 & Legal persons and arrangements & & & & $\mathrm{x}$ \\
\hline IO.6 & Financial intelligence & & & $\mathrm{x}$ & \\
\hline IO.7 & ML investigation and prosecution & & & $x$ & \\
\hline IO.8 & Confiscation & & & $\mathrm{x}$ & \\
\hline IO.9 & TF investigation and prosecution & & $\mathrm{x}$ & & \\
\hline I0.10 & TF preventive measures and financial sanctions & & $x$ & & \\
\hline \multirow[t]{2}{*}{ I0.11 } & PF financial sanctions & & & $\mathrm{x}$ & \\
\hline & Total & - & 5 & 5 & 1 \\
\hline
\end{tabular}

3. Going forward, Canada's priority actions should include: (i) ensuring that legal counsels, legal firms and Quebec notaries are brought within the AML/CFT regime; (ii) increasing the timeliness of access by competent authorities to accurate and up-to-date beneficial ownership information; (iii) increase timely access to financial intelligence, notably by authorizing FINTRAC to request and obtain further information related to suspicions of $\mathrm{ML}$, predicate offenses and TF from any reporting entity; (iv) using financial intelligence to a greater extent to investigate $\mathrm{ML}$ and trace assets; $(v)$ increasing efforts to detect, pursue and bring before the courts different types of $\mathrm{ML}$ cases; (vi) ensuring that asset recovery is pursued as a policy objective; (vii) ensuring compliance by all financial institutions with the requirements to confirm the accuracy of beneficial ownership in relation to all customers; (viii) required designated non-financial sectors to identify and verify the identity of beneficial owners and politically exposed persons; (ix) coordinating more effectively 
supervision of federally regulated financial institutions; and (x) ensuring that FINTRAC develops sector-specific expertise and applies more intensive supervisory measures to the real estate and dealers in previous metals and stones sectors.

\section{Recent progress by the authorities}

4. Canada is committed to a strong and comprehensive AML/CFT regime. Since the assessment, the authorities have taken actions to improve the AML/CFT regime and respond to emerging risks. The authorities have passed amendments to the AML/CFT regulations in June 2016, to clarify that online casinos are subject to the AML/CFT regime, expand the requirements to domestic politically exposed persons and require an assessment of the money laundering and terrorist financing risks of new technologies. In the 2017 Budget, the Government expressed its commitment to work towards putting in place a national strategy to strengthen the transparency of legal persons and legal arrangements, improve the availability of beneficial ownership information, and propose legislative amendments to the Proceeds of Crime (Money Laundering) and Terrorist Financing Act to strengthen the AML/CFT framework further. 


\section{Annex V. 2014 FSAP Key Recommendations and Implementation}

\section{There has been little progress in addressing several major recommendations of the FSAP:}

- Clear and explicit regulatory mandates to monitor systemic risk to facilitate macro-prudential oversight and carry out system-wide crisis preparedness continue to be missing.

- Consistent with Basel Core Principles, legislation should be amended to give OSFI operational independence without ministerial power to override supervisory judgment.

- Legislation should be amended to give OSFI the authority to conduct group-wide supervision, a key component of the Insurance Core principles, to promote a consolidated view of risks and prevent arbitrage across differently regulated structures within the group.

\begin{tabular}{|c|c|c|}
\hline Recommendation & $\begin{array}{l}\text { Time } \\
\text { Frame }\end{array}$ & Update since 2014 Article IV \\
\hline $\begin{array}{l}\text { Reduce government exposure to } \\
\text { mortgage insurance gradually. }\end{array}$ & Long term & $\begin{array}{l}\text { The authorities introduced a range of measures over the past several years, including } \\
\text { more recently in December } 2015 \text { (see Section D in the main text). }\end{array}$ \\
\hline $\begin{array}{l}\text { Include major regulated entities at } \\
\text { federal and provincial level in a } \\
\text { regular, common stress testing } \\
\text { exercise with collaboration between } \\
\text { relevant federal and provincial } \\
\text { authorities. }\end{array}$ & Short term & $\begin{array}{l}\text { The Bank of Canada has provided quantitative scenarios, detailed macro stress testing } \\
\text { instructions, advice and technical assistance to the Autorité des Marchés financiers (AMF) } \\
\text { (Quebec) to support their stress testing build out. } \\
\text { The Bank also had detailed technical discussions related to macro stress testing capacity } \\
\text { building (e.g., probability of default modeling) with the British Columbia Financial } \\
\text { Institutions Commission. }\end{array}$ \\
\hline $\begin{array}{l}\text { Equip OSFI with powers to make its } \\
\text { own enforceable rules by } \\
\text { administrative means, supplementing } \\
\text { the use of guidelines and government } \\
\text { regulations; amend legislation on } \\
\text { statutory decisions to give OSFI sole } \\
\text { decision- making authority on } \\
\text { prudential criteria. }\end{array}$ & $\begin{array}{l}\text { Medium } \\
\text { term }\end{array}$ & $\begin{array}{l}\text { The authorities do not intend to pursue this recommendation. } \\
\text { Authorities' response "OSFI's administrative guidelines are enforceable in practice because } \\
\text { its numerous intervention powers and tools are legally enforceable. OSFI's use of } \\
\text { guidelines provides OSFI with the ability to act independently and quickly in the face of } \\
\text { emerging risks." }\end{array}$ \\
\hline $\begin{array}{l}\text { Replace certain informal and ad hoc } \\
\text { reporting requirements by FRFIs with } \\
\text { more formal requirements (in keeping } \\
\text { with BCP } 1,2 \text { and ICP } 1,2 \text { ) }\end{array}$ & $\begin{array}{l}\text { Medium } \\
\text { term }\end{array}$ & $\begin{array}{l}\text { Use of the Regulatory Data Governance Framework to provide a transparent process for } \\
\text { prioritizing regulatory data requirements and regulatory data lifecycle management, } \\
\text { thereby ensuring that regulatory data is managed as an OSFI-wide strategic enterprise } \\
\text { asset. } \\
\text { In } 2016 \text {, the existing ad hoc collection of Own Risk and Solvency Assessment (ORSA) Key } \\
\text { Metrics will be replaced with a formal regulatory return. }\end{array}$ \\
\hline $\begin{array}{l}\text { Adopt a transparent and consistent } \\
\text { regulatory regime for group-wide } \\
\text { insurance supervision; give OSFI the } \\
\text { authority to take supervisory measures } \\
\text { at the level of the holding company. }\end{array}$ & $\begin{array}{l}\text { Medium } \\
\text { term }\end{array}$ & $\begin{array}{l}\text { The authorities do not intend to pursue this recommendation. } \\
\text { Authorities' response, "Canada is satisfied with OSFI's current approach to group-wide } \\
\text { supervision of the largest insurance companies and will not be seeking legislative } \\
\text { amendments." }\end{array}$ \\
\hline $\begin{array}{l}\text { Augment OSFI's top-down stress } \\
\text { testing framework for banks with risk- } \\
\text { sensitive concepts of credit risk input } \\
\text { parameters and econometric, model- } \\
\text { based efforts using longer time series. }\end{array}$ & Short term & The authorities will consider this in the future, as the stress testing framework evolves. \\
\hline
\end{tabular}




\begin{tabular}{|c|c|c|}
\hline Recommendation & $\begin{array}{c}\text { Time } \\
\text { Frame }\end{array}$ & Update since 2014 Article IV \\
\hline $\begin{array}{l}\text { Expand financial sector data collection } \\
\text { and dissemination with a view to } \\
\text { enhancing coverage, regularity, and } \\
\text { availability of time-series to facilitate } \\
\text { analysis (in keeping with BCP } 28 \text {, ICP } \\
20, \text { IOSCO } 6,7 \text { ) }\end{array}$ & Short term & 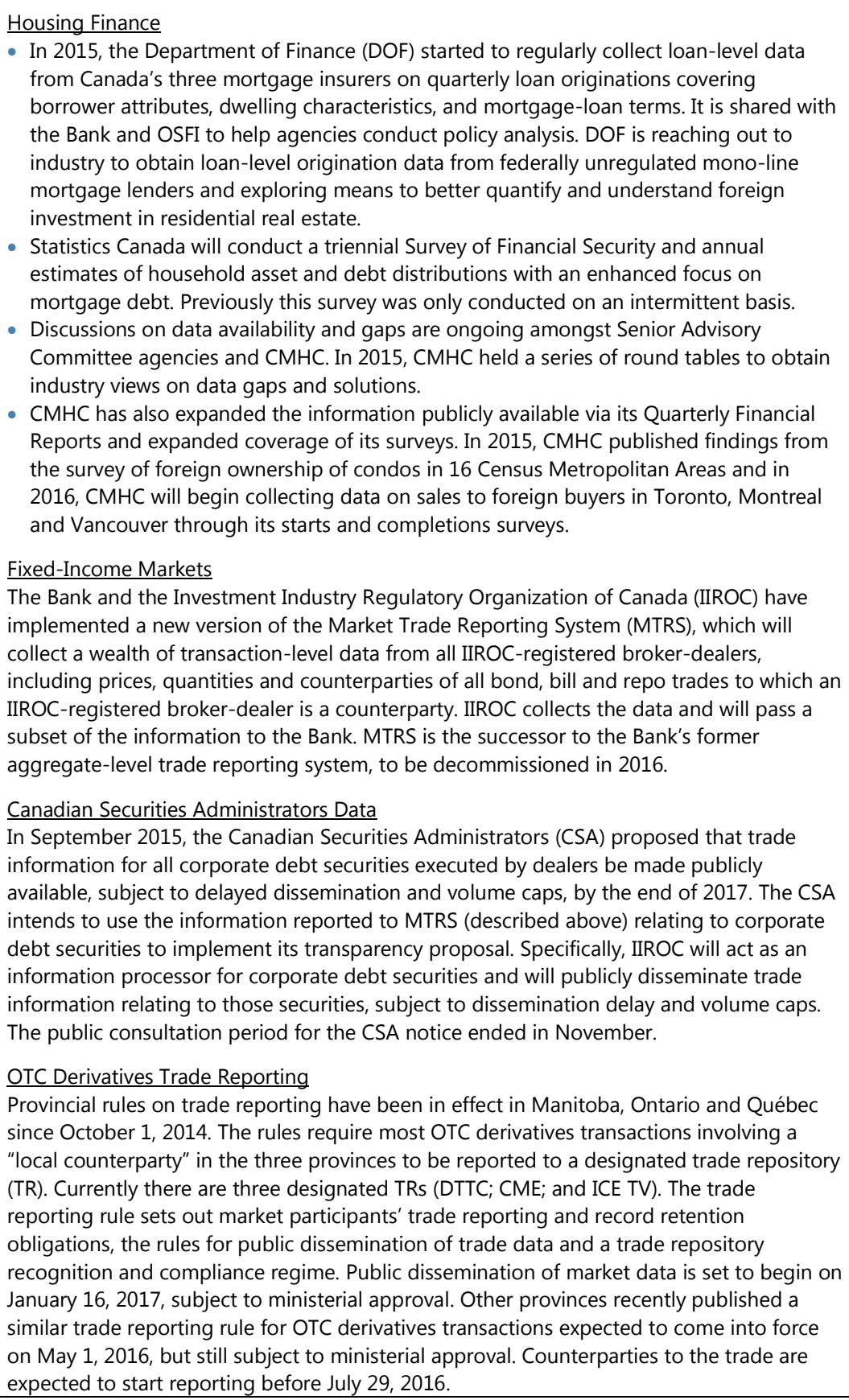 \\
\hline $\begin{array}{l}\text { Address shortcomings in risk } \\
\text { identification and enforcement in } \\
\text { securities regulation. }\end{array}$ & Short term & $\begin{array}{l}\text { In July 2015, the Council of Ministers, comprised of the provincial and territorial Ministers } \\
\text { responsible for securities regulation in British Columbia, Ontario, Saskatchewan, New } \\
\text { Brunswick, Prince Edward Island and Yukon, and the Minister of Finance Canada, } \\
\text { announced that Mr. William A. Black would be the chair of the Capital Markets Regulatory } \\
\text { Authority's initial board of directors. } \\
\text { In August 2015, participating jurisdictions released an updated consultation draft } \\
\text { provincial and territorial capital markets legislation, along with draft initial regulations, for } \\
\text { public comment. Participating jurisdictions are assessing the comments received. }\end{array}$ \\
\hline
\end{tabular}




\begin{tabular}{|l|l|l|}
\hline \multicolumn{1}{|c|}{ Recommendation } & \multicolumn{1}{|c|}{$\begin{array}{c}\text { Time } \\
\text { Frame }\end{array}$} & Update since 2014 Article IV \\
\hline $\begin{array}{l}\text { Enhance supervisory cooperation } \\
\text { among federal and provincial } \\
\text { supervisors and subject all systemically } \\
\text { significant financial institutions to } \\
\text { intensive supervision (BCP 3, ICP3) }\end{array}$ & Short term & $\begin{array}{l}\text { OSFI and the AMF have instituted a new cooperation framework whereby meetings are } \\
\text { scheduled on a regular basis to discuss issues of mutual interest, in addition to existing } \\
\text { consultation procedures. }\end{array}$ \\
\hline $\begin{array}{l}\text { Provide a clear mandate to an entity (i) } \\
\text { to monitor systemic risk to facilitate } \\
\text { macro-prudential oversight, and (ii) to } \\
\text { carry out system-wide crisis } \\
\text { preparedness. }\end{array}$ & Short term & $\begin{array}{l}\text { The authorities do not intend to pursue this recommendation. } \\
\text { Authorities' response, "as noted in the previous FSAP, the regulatory and supervisory } \\
\text { framework demonstrates strong compliance with international standards and is well } \\
\text { coordinated across the federal oversight bodies. Responsibility for addressing systemic } \\
\text { risk remains with the Senior Advisory Committee, a non-statutory body chaired by the } \\
\text { Deputy Minister of Finance." }\end{array}$ \\
\hline $\begin{array}{l}\text { Increase the ex-ante funding of CDIC } \\
\text { and enhance its data collection and } \\
\text { analysis of depositor profiles. }\end{array}$ & $\begin{array}{l}\text { Medium } \\
\text { term }\end{array}$ & $\begin{array}{l}\text { The minimum target level of CDIC's ex ante funding is 100 basis points of insured } \\
\text { deposits. CDIC continues to progressively increase its ex ante fund to reach this target. }\end{array}$ \\
\hline
\end{tabular}


Annex VI. 2017 Federal Budget Measures to Enhance Innovation, Skills, and Clean Technology

\begin{tabular}{|c|c|c|c|c|}
\hline & \multicolumn{2}{|c|}{ FY2017 } & \multicolumn{2}{|c|}{ Total FY2017-FY2021 } \\
\hline & $\begin{array}{c}\text { Billions } \\
\text { of } C \$\end{array}$ & $\begin{array}{l}\text { Percent } \\
\text { of GDP }\end{array}$ & $\begin{array}{r}\text { Billions } \\
\text { of } C \$\end{array}$ & $\begin{array}{l}\text { Percent } \\
\text { of GDP }\end{array}$ \\
\hline \multicolumn{5}{|l|}{ Skills } \\
\hline Helping Canadians Get New and Better Jobs & 0.2 & 0.01 & 2.1 & 0.09 \\
\hline Helping Working Adults Upgrade Their Skills & 0.0 & 0.00 & 0.5 & 0.02 \\
\hline \multicolumn{5}{|l|}{ Expanding Employment Insurance Benefits to Offer } \\
\hline More Flexibility for Families & 0.1 & 0.01 & 0.9 & 0.04 \\
\hline \multicolumn{5}{|l|}{ Improving the Temporary Foreign Worker Program } \\
\hline and the International Mobility Program & 0.1 & 0.00 & 0.3 & 0.01 \\
\hline Other programs & 0.4 & 0.02 & 1.5 & 0.07 \\
\hline Sub total & 0.8 & 0.04 & 5.2 & 0.23 \\
\hline \multicolumn{5}{|l|}{ Innovation } \\
\hline Accelerating Innovation Through Superclusters & 0.1 & 0.00 & 1.0 & 0.04 \\
\hline \multicolumn{5}{|l|}{ The New Strategic Innovation Fund and Venture } \\
\hline Capital & 0.1 & 0.00 & 0.2 & 0.01 \\
\hline Other programs & 0.2 & 0.01 & 0.5 & 0.02 \\
\hline Sub total & 0.3 & 0.02 & 1.7 & 0.07 \\
\hline \multicolumn{5}{|l|}{ Clean Tech, digital, and agri-food } \\
\hline Clean technology & 0.1 & 0.00 & 1.1 & 0.05 \\
\hline Other programs & 0.0 & 0.00 & 0.1 & 0.00 \\
\hline Sub total & 0.1 & 0.00 & 1.1 & 0.05 \\
\hline Total programs & 1.2 & 0.06 & 8.1 & 0.35 \\
\hline
\end{tabular}

Source: Federal Budget 2017, Table 1.3., and Fall Economic Statement 2016. 


\section{INTERNATIONAL MONETARY FUND}

\section{CANADA}

STAFF REPORT FOR THE 2017 ARTICLE IV

June 21, 2017 CONSULTATION-INFORMATIONAL ANNEX

Prepared By

The Western Hemisphere Department

(in consultation with other departments)

\section{CONTENTS}

FUND RELATIONS $\underline{2}$ 


\section{FUND RELATIONS}

(As of May 31, 2017)

Membership Status: Joined 12/27/1945; Article VIII

\section{General Resources Account:}

Quota

Fund holdings of currency

Reserve Tranche Position

Lending to the Fund

New Arrangements to Borrow

\section{SDR Department:}

Net cumulative allocation

Holdings
SDR Million

$11,023.90$

$10,048.77$

975.16

623.08

SDR Million

$5,988.08$

$5,635.35$
Percent of Quota

100.00

91.15

8.85

Outstanding Purchases and Loans: None.

Latest Financial Arrangements: None.

\section{Projected Obligations to Fund:}

(SDR Million; based on existing use of resources and present holdings of SDRs):

\begin{tabular}{lccccc} 
& \multicolumn{5}{c}{ Forthcoming } \\
& 2017 & 2018 & 2019 & 2020 & 2021 \\
\cline { 2 - 6 } Principal & & & & \\
Charges/Interest & 0.97 & 2.12 & 2.12 & 2.12 & 2.12 \\
Total & 0.97 & 2.12 & 2.12 & 2.12 & 2.12
\end{tabular}

Implementation of HIPC Initiative: Not Applicable.

Implementation of Multilateral Debt Relief Initiative (MDRI): Not Applicable.

Implementation of Post-Catastrophe Debt Relief (PCDR): Not Applicable.

Exchange Rate Arrangements: The authorities maintain a "free floating" exchange rate regime. The exchange rate regime is free from exchange restrictions and multiple currency practices. The Canadian authorities do not maintain margins with respect to exchange transactions. However, the authorities may intervene to maintain orderly conditions in the exchange market. There are no taxes or subsidies on purchases or sales of foreign exchange. Canada has accepted the obligations of Article VIII, Sections 2, 3, and 4 (a), and maintains an exchange system that is free of restrictions on 
the making of payments and transfers for current international transactions. Canada maintains exchange restrictions for security reasons, based on UN Security Council Resolutions, that have been notified to the Fund for approval (most recently in June 10, 2014) under the procedures set forth in Executive Board Decision No. 144-(52/51).

Last Article IV Consultation: The Staff Report for the 2016 consultation with Canada was considered by the Executive Board on June 6, 2016 (IMF Country Report No. 16/146). Canada is on a 12-month consultation cycle.

2017 Article IV Consultation: Discussions took place in Toronto and Ottawa during May 15-26 and May 30-31, 2017. The team comprised Cheng Hoon Lim (head), Kotaro Ishi, Yulia Ustyugova (all WHD), Zsofia Arvai (MCM), and David Gentry (FAD). Messrs. Werner and Srinivasan (both WHD) and Ms. Horsman (ED) joined the mission for the concluding meeting in Ottawa. Ms. Young and Ms. Zorn (OED) accompanied the mission. The mission met with Finance Minister Morneau, Governor Poloz, Superintendent Rudin, Deputy Minister Rochon, Deputy Governors Lane and Schembri, other senior officials, regulators, provincial governments, representatives from the financial and business sector, academics, and think tanks. The press conference was held on May 31 , 2017 in Ottawa.

\section{FSSA Participation and ROSC Assessments}

\section{Canada: Financial System Stability Assessment- www.imf.org Volume II: Report on Observance of Standards in June 30,2000 the Financial System}

Summary: The FSSA report concluded that Canada has a stable and highly advanced financial system, which is among the soundest in the world. It is supported by a well-developed regulatory system that shows a high degree of compliance with major international standards. The FSSA report made a few recommendations to further strengthen the regulatory framework and financial system's resilience, most of which have already been addressed, including:

- Introducing capital requirements for the guarantees in life insurance segregated fund (completed by end-2001);

- $\quad$ Tabling legislation granting the Office of the Superintendent of Financial Institutions (OSFI) powers to remove a financial institution's director or senior officer if the person is deemed not suitable to hold that office based on a number of criteria. The latter legislation brought Canada into broad compliance with the Basel Core Principles;

- Making significant progress in harmonizing securities regulation and improving coordination among provincial securities regulators, including through a newly created association of securities regulators, the Canadian Securities Administrators. Although there remain multiple regulators at the provincial level, a Senate commission was created to develop specific recommendations on further harmonization and streamlining of securities regulation. 


\section{Canada: Report on the Observance of Standards and Codes-Fiscal Transparency Module}

IMF Country Report

No. $02 / 51,03 / 12 / 02$

Summary: The report found that fiscal management in Canada meets the requirements of the fiscal transparency code, and in a number of instances represents best practice. In particular, it highlighted the use of private sector economic forecasts. Fiscal management was also commended for its statistical integrity, impartial tax administration, open procurement, and a transparent regulatory process.

The report found several areas where further improvements would be desirable, including: (i) the preparation of timely, current year estimates of federal and provincial budgets on a comparable basis, (ii) a comprehensive account of the procedures for the budget cycle and expenditure management system, (iii) systematic reporting of the use of reserves for non-economic contingencies, (iv) resumption of publication of reconciled national and public accounts forecasts of major aggregates over the forecast horizon, and ( $v$ ) publication by all governments of quasifiscal activities.

Many of these issues have been addressed, including: (i) the release by Statistics Canada of consolidated data for federal and provincial budgets for 2001-02 (on a Financial Management System basis); (ii) the publication of comprehensive descriptions of budget and expenditure management procedures, including a joint document entitled "Budgeting in Canada" by the Government and the OECD, detailed accounts of policies and procedures on expenditure management at the website of the Treasury Board Secretariat, and the explanation of the budget cycle and process in Budget and Update documents; and (iii) publication of reconciled national and public accounts forecasting.

\section{Canada: Report on the Observance of Standards and Codes-Data Module}

IMF Country Report No. 03/328, $10 / 23 / 03$

Summary: Canada's macroeconomic statistics are comprehensive, timely, and accurate and thus adequate to conduct effective surveillance of economic and financial policies. Official institutions responsible for the compilation and dissemination of the macroeconomic datasets are supported by adequate legal and institutional frameworks. These frameworks protect confidentiality and ensure that statistical work is conducted within a quality assurance program and with sufficient resources. Integrity is ensured by the professionalism of the staff, transparency in statistical policies and practices, and the provision of ethical guidelines for staff. Compilers generally follow internationally accepted guidelines in the production of the macroeconomic statistics, which is well-supported by excellent efforts to develop source data that facilitate a high degree of accuracy and reliability. Statistics are generally relevant, well documented, available with good frequency on a timely basis, and readily accessible to users, who trust them as objective.

While recognizing the high quality of the macroeconomic data, the report makes recommendations to further strengthen the statistical system, most of which are already being addressed, including these priorities: 
- Articulate the roles of Statistics Canada and the Bank of Canada in producing financial sector statistics and explore possibilities for more data sharing of monetary and financial statistics;

- Estimate consumption of fixed capital at replacement cost rather than historic costs now used for the corporate sector in the Canadian System of National Accounts (CSNA);

- Disseminate information on the sources and methods used in compiling quarterly public sector statistics for the quarterly CSNA; and

- Reclassify certain transactions that are not recorded in line with the $5^{\text {th }}$ edition of the Balance of Payments Manual (BPM5).

Canada: Report on the Observance of Standards and Codes-FATF Recommendations for AntiMoney Laundering and Combating the Financing of Terrorism
IMF Country Report No. 08/372, $12 / 11 / 08$

Summary: Canada's anti-money laundering and combating the financing of terrorism (AML/CFT) framework was last assessed by the Financial Action Task Force (FATF) and the Asia Pacific Group on Money Laundering (APG) in March 2007. Shortcomings were identified in particular with respect to the scope of customer due diligence, the implementation of AML/CFT supervision, and the effectiveness of the financial intelligence unit (FINTRAC). Since 2007, Canada submitted six followup reports to the FATF, the last one in February 2014, and took a number of steps to strengthen the framework in these areas. The next mutual evaluation of Canada will be conducted by the Fund and is scheduled in the fourth quarter of 2015.

Canada: Financial System Stability AssessmentUpdate
IMF Country Report No. 08/59,

02/13/08

Summary: The FSSA update concluded that Canada's financial system is mature, sophisticated, and well-managed. Financial stability was underpinned by sound macroeconomic policies and strong prudential regulation and supervision, and well-designed deposit insurance and arrangements for crisis management and failure resolution. The banking system appeared sound, with stress tests showing that the major banks could withstand sizeable shocks, although they did faces some challenges related to the global financial turmoil that started in mid-2007. Also, there were some concerns about bank attempts to build on their secure domestic position, to enter highly competitive foreign markets or complex activities. The update reiterated the advantages of moving towards a single securities regulator, including the streamlining of policy development, reductions in compliance costs, and improved enforcement. However, it also recognized the significant improvements to the regulatory system from the creation of the Canadian Securities Administrators (CSA), and the implementation of the passport system. 
Canada: Financial System Stability AssessmentUpdate
IMF Country Report No. 14/29,

02/03/14

Summary: The FSSA Update found that Canada's financial system successfully navigated the global financial crisis, and stress tests suggest that major Canadian financial institutions are resilient to credit, liquidity, and contagion risks arising from a severe stress scenario. Elevated house prices and high household debt remain an area of concern (despite the substantial level of government-guaranteed mortgage insurance), though targeted prudential and macro-prudential measures are proving to be effective. The regulatory and supervisory framework demonstrates strong compliance with international standards. Nevertheless, the Update called for more clarity around the legal independence of OSFI and for assigning stronger prudential responsibilities to this regulator. In the securities markets, provincial regulators and the federal government have made significant progress in implementing a robust and harmonized framework, but challenges remain in enforcement, risk identification, and timely policy making. The FSSA Update argued that the federal system of safety nets is credible, although there is no single body with an explicit mandate to take a comprehensive view of systemic risks or to undertake crisis preparedness. Improving cooperation between federal and provincial authorities would further reinforce systemwide oversight arrangements.

Canada: Report on the Observance of Standards and Codes-FATF Recommendations for AntiMoney Laundering and Combating the Financing of Terrorism (AML/CFT)
IMF Country Report No. 16/293, 09/15/16

Summary: This report evaluates the observance of standards and codes on Financial Action Task Force recommendations for anti-money laundering and combating the financing of terrorism (AML/CFT) in Canada. The findings reveal that the Canadian authorities have a good understanding of most of Canada's money laundering and terrorism financing risks. AML/CFT cooperation and coordination are generally good at the policy and operational levels. All high-risk areas are covered by AML/CFT measures, except legal counsel, legal firms, and Quebec notaries. This constitutes a significant loophole in Canada's AML/CFT framework. Law enforcement results are not commensurate with the money-laundering risk, and asset recovery is low.

Technical Assistance: Not Applicable.

Resident Representative: Not Applicable.

\section{STATISTICAL ISSUES}

The quality, coverage, periodicity, and timeliness of Canada's economic data are considered to be adequate both in the context of the Article IV consultation and for purposes of ongoing surveillance. Canada has subscribed to the Fund's Special Data Dissemination Standard (SDDS), and its metadata are posted on the Fund's Dissemination Standards Bulletin Board (DSBB). The data ROSC was published on October 23, 2003. 
Real Sector. Statistics Canada provides timely and adequate data in monthly, quarterly, and annual frequency thereby facilitating the analyses of economic developments and policy assessments within a quantitative macroeconomic framework. In October 2012, Statistics Canada started aligning the Canadian System of National Accounts (CSNA) with the SNA2008 international standard. The changes introduced in the CSNA2012 included, among others, capitalization of research and development, move to replacement cost-based valuation of consumption of fixed capital, and valuing equity more consistently at market price. Additional changes were introduced with the 2014 release of the CSNA, which for the most part did not have a significant impact on GDP and represented the development of new accounts, improved integration between the CSNA and Government Finance Statistics, additional detail, and presentational changes that better align with international standards (see, Statistics Canada). In 2015 Statistics Canada carried out comprehensive revision to the Canadian System of Macroeconomic Accounts (CSMA). The four main sources of revision with that release of the CSMA were: the integration of Government Finance Statistics, the improved treatment of defined benefit pension plans, the measurement of financial services purchased by households', and updated measures of national wealth.

Fiscal Sector. Statistics Canada provides quarterly data (a Statement of Government Operations along with a Balance Sheet) on the general government and its subsectors following the Government Finance Statistics Manual 2001 (GFSM 2001) recommendations. In November 2014, Statistics Canada published the provisional (unconsolidated) data on Canadian Government Finance Statistics (CGFS) for 2008-2012. This covers the statement of operations for all components of general government, as well as federal and provincial and territorial government business enterprises. Data on the functional expenses were also released. Subsequently, in February 2015, estimates for financial flows and the balance sheet of the general government and government business enterprises for 2007-2012 were published. Statistics Canada published Consolidated Government Finance Statistics data for 2008-2014 for the first time in March 2016 and for 2015 in March 2017. In addition, the Department of Finance Canada provides monthly and annual data on the federal government's budget (according to the national presentation) and tax policies. The provided data enable adequate assessment of the impact of fiscal policy measures on Canada's economic performance.

Financial Sector. The Bank of Canada and OSFI provide monthly and quarterly data on the broad range of financial variables. However, the 2013 FSSA Update recommended that financial sector data collection and dissemination should be expanded with a view to enhancing coverage, regularity, and availability of time-series to facilitate analysis.

Monetary Sector. The Bank of Canada provides timely and adequate coverage of daily, weekly, monthly, and quarterly data related to the monetary sector.

External Sector. Statistics Canada provides timely information on a quarterly frequency on the balance of payments, external debt, and the international investment position. Department of Finance Canada provides monthly data on Official International Reserves in a format comparable to the IMF's reserve data template, thus enabling adequate surveillance. 


\begin{tabular}{|c|c|c|c|c|c|c|c|}
\hline \multicolumn{8}{|c|}{ Canada: Table of Common Indicators Required For Surveillance } \\
\hline & \multirow{2}{*}{$\begin{array}{l}\text { Date of latest } \\
\text { observation }\end{array}$} & \multirow{2}{*}{ Date received } & \multirow{2}{*}{$\begin{array}{l}\text { Frequenc } \\
\text { y of } \\
\text { Data }^{6}\end{array}$} & \multirow{2}{*}{$\begin{array}{l}\text { Frequency } \\
\text { of } \\
\text { Reporting }^{6}\end{array}$} & \multirow{2}{*}{$\begin{array}{l}\text { Frequency of } \\
\text { Publication }^{6}\end{array}$} & \multicolumn{2}{|c|}{ Memo Items: } \\
\hline & & & & & & $\begin{array}{l}\text { Data Quality - } \\
\text { Methodologic } \\
\text { al soundness }\end{array}$ & $\begin{array}{l}\text { Data Quality - } \\
\text { Accuracy and } \\
\text { reliability }^{8}\end{array}$ \\
\hline Exchange Rates & Same day & Same day & D & $\mathrm{D}$ & $\mathrm{D}$ & & \\
\hline $\begin{array}{l}\text { International Reserve Assets and } \\
\text { Reserve Liabilities of the Monetary } \\
\text { Authorities }^{1}\end{array}$ & June 15, 2017 & June 16, 2017 & W & W & W & & \\
\hline Reserve/Base Money & June 14, 2017 & June 16, 2017 & W & W & w & \multirow{4}{*}{ LO, O, LO, LO } & \multirow{4}{*}{$0,0,0,0,0$} \\
\hline Broad Money & $\begin{array}{l}\text { End April, } \\
2017\end{array}$ & May 29, 2017 & M & M & M & & \\
\hline Central Bank Balance Sheet & June 14, 2017 & June 16, 2017 & W & W & W & & \\
\hline $\begin{array}{l}\text { Consolidated Balance Sheet of the } \\
\text { Banking System }\end{array}$ & $\begin{array}{l}\text { End April, } \\
2017\end{array}$ & May 29, 2017 & M & M & M & & \\
\hline Interest Rates ${ }^{2}$ & Same day & Same day & $\mathrm{D}$ & $\mathrm{D}$ & $\mathrm{D}$ & & \\
\hline Consumer Price Index & April 2017 & May 19, 2017 & M & M & M & $0,0,0,0$ & $\begin{array}{l}\mathrm{O}, \mathrm{O}, \mathrm{O}, \mathrm{O}, \\
\mathrm{NA}\end{array}$ \\
\hline $\begin{array}{l}\text { Revenue, Expenditure, Balance and } \\
\text { Composition of Financing }{ }^{3}- \\
\text { General Government }{ }^{4}\end{array}$ & 2017 Q1 & May 31, 2017 & Q & Q & $\mathrm{Q}$ & \multirow[t]{2}{*}{$0,0,0,0$} & \multirow[t]{2}{*}{$0,0,0,0,0$} \\
\hline $\begin{array}{l}\text { Revenue, Expenditure, Balance and } \\
\text { Composition of Financing }{ }^{3}-\text { Central } \\
\text { Government }\end{array}$ & Mar 2017 & May 26, 2017 & M & M & M & & \\
\hline External Current Account Balance & 2017 Q1 & May 30, 2017 & Q & $\mathrm{Q}$ & Q & \multirow[b]{2}{*}{ O, O, LO, O } & \multirow[b]{2}{*}{$0,0,0,0,0$} \\
\hline $\begin{array}{l}\text { Exports and Imports of Goods and } \\
\text { Services }\end{array}$ & April 2017 & June 2, 2017 & M & M & M & & \\
\hline GDP/GNP & 2017 Q1 & May 31, 2017 & Q & Q & Q & O, O, O, LO & $0,0,0,0,0$ \\
\hline Gross External Debt & 2017 Q1 & June 13, 2017 & Q & Q & $\mathrm{Q}$ & & \\
\hline International Investment Position ${ }^{5}$ & 2017 Q1 & June 13, 2017 & $\mathrm{Q}$ & $\mathrm{Q}$ & $\mathrm{Q}$ & & \\
\hline \multicolumn{8}{|c|}{$\begin{array}{l}{ }^{1} \text { Any reserve assets that are pledged or otherwise encumbered should be specified separately. Also, data should comprise short-term liabilities linked } \\
\text { to a foreign currency but settled by other means as well as the notional values of financial derivatives to pay and to receive foreign currency, including } \\
\text { those linked to a foreign currency but settled by other means. } \\
{ }^{2} \text { Both market-based and officially-determined, including discount rates, money market rates, rates on treasury bills, notes and bonds. } \\
{ }^{3} \text { Foreign, domestic bank, and domestic nonbank financing. } \\
{ }^{4} \text { The general government consists of the central government (budgetary funds, extra budgetary funds, and social security funds) and state and local } \\
\text { governments. } \\
{ }^{5} \text { Includes external gross financial asset and liability positions vis-à-vis nonresidents. } \\
{ }^{6} \text { Daily (D); weekly (W); monthly (M); quarterly (Q); annually (A); irregular (I); and not available (NA). } \\
{ }^{7} \text { Reflects the assessment provided in the data ROSC published on October } 23,2003 \text { and based on the findings of the mission that took place during } \\
\text { January } 22-\text { February 5, } 2003 \text { for the dataset corresponding to the variable in each row. The assessment indicates whether international standards } \\
\text { concerning (respectively) concepts and definitions, scope, classification/sectorization, and basis for recording are fully observed (O), largely observed } \\
\text { (LO), largely not observed (LNO), not observed (NO); and not available (NA). } \\
{ }^{8} \text { Same as footnote } 8 \text {, except referring to international standards concerning (respectively) source data, assessment of source data, statistical techniques, } \\
\text { assessment and validation of intermediate data and statistical outputs, and revision studies. }\end{array}$} \\
\hline
\end{tabular}

